Matias Rebello Cardomingo

Understanding liberalization episodes through the product space approach

Analisando episódios de liberalização através da abordagem de espaço de produtos 
Prof. Dr. Vahan Agopyan

Reitor da Universidade de São Paulo

Prof. Dr. Fábio Frezatti

Diretor da Faculdade de Economia, Administração e Contabilidade

Prof. Dr. Jose Carlos de Souza Santos

Chefe do Departamento de Economia

Prof. Dr. Ariaster Baumgratz Chimeli

Coordenador do Programa de Pós-Graduação em Economia 
Matias Rebello Cardomingo

\title{
Understanding liberalization episodes through the product space approach
}

\section{Analisando episódios de liberalização através da abordagem de espaço de produtos}

\author{
Dissertação apresentada ao Programa de \\ Pós-Graduação em Economia da Faculdade \\ de Administração, Economia, Contabilidade \\ e Ciências Atuariais da Universidade de São \\ Paulo como requisito parcial para obtenção \\ do título de mestre. \\ Versão Corrigida \\ (versão original disponível na Biblioteca da Faculdade de Economia, Administração e Contabilidade) \\ Universidade de São Paulo \\ Faculdade de Economia, Administração, Contabilidade e Ciências Atuariais - FEA
}

Orientador: Prof. Dr. Fernando Rugitsky

Brasil

2020 
Catalogação na Publicação (CIP)

Ficha Catalográfica com dados inseridos pelo autor

\section{Cardomingo, Matias Rebello.}

Understanding liberalization episodes through the product space approach / Matias Rebello Cardomingo. - São Paulo, 2020.

$73 \mathrm{p}$.

Dissertação (Mestrado) - Universidade de São Paulo, 2020.

Orientador: Fernando Rugistky.

1. Economia da Complexidade. 2. Política Comercial e Desenvolvimento. 3. Reformas de Liberalização. I. Universidade de São Paulo. Faculdade de Economia, Administração e Contabilidade. II. Título. 


\section{Understanding liberalization episodes through the product space approach}

\section{Analisando episódios de liberalização através da abordagem de espaço de produtos}

Dissertação apresentada ao Programa de Pós-Graduação em Economia da Faculdade de Administração, Economia, Contabilidade e Ciências Atuariais da Universidade de São Paulo como requisito parcial para obtenção do título de mestre.

Prof. Dr. Fernando Rugitsky

Orientador

Professor Dr. Dominik Hartmann

Professora Dra. Laura Carvalho

Professor Dr. Paulo Gala

Brasil

2020 


\section{Agradecimentos}

Agradeço à luta de quem ergueu tudo aquilo que pude vivenciar até agora.

À minha família agradeço por ter construído um ambiente de segurança e liberdade que foi condição necessária para que eu chegasse onde cheguei. Aos meus pais, Deborah e Ayrton, só tenho a agradecer pela compreensão e pelo amor que nunca deixaram faltar. À minha avó, Matilde, minha madrasta, Ana, e minha irmã, Clara, agradeço pelo companheirismo e pelas alegrias que temos juntos.

Como diz Emicida, ser mano igual Gil e Caetano, nesse mundo louco é para poucos e por isso agradeço muito a quem me alegra todos os dias e relembra a sorte que tenho: Lucas Câmara, Gabriela Orestes, Victor Vaccaro, Gabriel Jardanovski, Luis Alvarez, Ives Fernandes, Isabela Benassi, Vinicius Fernandes, Lucas Cavalcante, Nicole Herscovici e Alexandre Pupo. Para Clara Brenck guardo uma menção pelo carinho tão gostoso e inspirador; para Vitor Quarenta e André Bergel guardo ainda outro carinho especial pela convivência; para Rodrigo Toneto, por fim, agradeço pelo companheirismo sem tamanho, sem vocês seguramente não teria chegado até o fim.

Ao Partido dos Trabalhadores e sua militância, me alegro de poder integrar um projeto da classe trabalhadora que tenha tanta história e tanta vida. Entre seus acertos e contradições segue alimentando a utopia de quem deseja construir uma sociedade mais plural e menos desigual. Enquanto parte do cotidiano, agradeço quem faz dessa vivência algo ainda mais especial: Maria Alice Vieira, Rafael Valente, Barbara Martins, Cassiana Ferreira, Beatrice Weber, Lígia Toneto, Julia Kopf, Daniel Freitas, Ynaê Lolito e Vivian Mendes.

Por último, sou grato ao sistema de ensino e pesquisa público que permitiram uma convivência tão rica com o ambiente universitário em seus vários níveis. Agradeço em especial a quem compartilhou o ambiente da salinha de Pós-Graduação na FEA onde o café, o desespero e as boas ideias formaram boa parte desses mais de dois anos de mestrado. Para representar minha admiração por quem constrói com tanta dedicação o ambiente acadêmico, agredeço em especial ao Fernando Rugitksy, que conduziu o processo de orientação com muita abertura e paciência com meus desencontros, além de recomendações que se mostraram cada dia mais acertadas. Por fim, deixo meus agradecimentos às pessoas com quem pude ter mais trocas dentro ou fora da academia: Nilce Aravecchia, Fabiana Rocha, Laura Carvalho, Gilberto Tadeu Lima, André Singer e Márcio Nakane.

Agradeço também ao apoio financeiro que recebi ao longo desse período da Fundação Instituto de Pesquisas Econômicas (FIPE), da Coordenação de Aperfeiçoamento de Pessoal de Nível Superior (CAPES) na modalidade de bolsa Proex e, finalmente, ao Programa Ryaichi Sasakawa Young Leaders Fellowship Fund (Sylff). 
Se oriente, rapaz,

Pela constelação do Cruzeiro do Sul,

Se oriente, rapaz,

Pela constatação de que a aranha

Vive do que tece

Vê se não se esquece

Pela simples razão de que tudo merece

Consideração

(...)

Determine, rapaz

Onde vai ser seu curso de pós-graduação

Se oriente, rapaz

Pela rotação da Terra em torno do Sol

Gilberto Gil - Oriente (1972) 


\section{Foreword - Looking for a star}

The process of empowerment that started in the factories of São Bernardo was effective in part because it translated into fundamental political change at the national level $(. .).[$, it $]$ ensured that the transition to democracy corresponded to a move toward inclusive political institutions. Acemoglu and Robinson (2012)

Significance is not something theories are easily able to achieve. That is also true when it comes to works devoted to understanding economic growth, especially when these theories are under political disputes in the design of public policies. Thus, this thesis was born with the aspiration to contrast - through empirical methods - two branches of research on economic development that influenced the public debate in different periods and levels: one branch focused on building sound market institutions and correcting its failures, whereas the other had the sectoral composition of output at the center of its formulations. Even though such differences could be a matter of emphasis, pro-market formulations connected to the first branch were more likely to undervalue the productive structure in their theories - as in the potato and computer chips maxim - if compared to the valuing of market institutions by the structuralist branch. Therefore, the study's motivation was to question the prevalence of propositions in favor of market liberalization found in the mainstream Economics debate through significance stars that suggested the need to consider each country's productive capabilities for development strategies. Unfortunately, those stars were not reached; thus, this foreword aims to discuss which difficulties were left unaddressed and what was performed during this research.

At first, it seemed that using empirical methods was the best way to collate those strands of thoughts and to find evidence that could be valid for both sides, rather than using models that would raise disagreement from the assumptions. Besides, the product space method and the economic complexity research agenda, as proposed by Hidalgo and Hausmann, had proven to be an interesting tool to restate the need to consider the output composition in the economic growth theory, based on new empirical methods (HIDALGO et al., 2007; HIDALGO; HAUSMANN, 2009). Hirschman, one prominent figure among the pioneers of development economics, had already suggested that linkages between different economic sectors and unbalanced growth strategies could be tailored in order to deliver higher growth, given that the right decisions were taken by responsible policymakers or private planners (HIRSCHMAN, 1958). This proactive attitude to formulate growth strategies through the establishment of new productive capabilities brought the classical 
and the contemporary formulations on development closer, as it was carved in the building blocks of the economic complexity agenda (HIDALGO; HAUSMANN, 2009).

On the other side of the spectrum, the hypothesis formulated mainly by Acemoglu and Robinson in the early 2000s was chosen as representative of the institutional strand (ACEMOGLU; JOHNSON; ROBINSON, 2001; ACEMOGLU; JOHNSON; ROBINSON, 2002). This choice was based on the fact that their argument, and especially the favorable evidence they found, was highly influential and had little nuances about the major prevalence of property rights as the most crucial aspect for economic development - Jaime Ros, for instance, poses the duo as the rule of law thesis' strongest version (ROS, 2013). Besides that, reasoning uneven development based on institutional differences originated back in the colonial period became an obstacle for thinking about development today.

However, even this opposition was not consistent, as their argument would vindicate that better institutions were the main responsible for the structural change that Europe went through during the second half of the XVIII century. Output composition changes would be seen as a consequence of previously established institutions. Thus, Acemoglu and Robinson argued that such an innovation process was only made possible because there were already established "institutions of private property". It was only one decade later that they decided to change the label of such institutional arrangement renaming them as inclusive institutions. In other words, institutions that were able to guarantee the rule of law would from now on be called inclusive (ACEMOGLU; ROBINSON, 2012). The inclusiveness of those institutions was based on the idea that disruptive processes or creative destruction -, necessary for growth and prosperity, not only required a broad coalition to be able to produce and implement innovations, but also that ruling elites (both in political and economic spheres) could be dethroned without sabotaging new initiatives. Even though this reasoning was published for a wider audience, the idea that broad coalitions can achieve a more efficient allocation of resources resembled the definition of the core from Microeconomics' pure exchange economy theory, i.e. a collective solution equivalent to the one obtained in market societies.

When theorizing about Brazil, Acemoglu and Robinson chose the strikes in the 1970s as a reference period to when such a broader coalition was built and resulted in greater inclusiveness (ACEMOGLU; ROBINSON, 2012). They do not seem to find it relevant to question why it was this social movement, and not any other, that was able to become so significant in the political arena. One can not ignore the fact that this movement was precisely a worker's organization from one of the most advanced Brazilian industries at the time - something that those political leaders were conscious about. The emergence of a political agenda set by workers was, in a certain way, made possible because it came from the very edge of the Brazilian productive structure. Such example, therefore, actually illustrates what the economic complexity agenda has been arguing: enhancing one 
nation's capabilities is a process that strengthens social cohesion and lowers inequality ${ }^{1}$ (HARTMANN et al., 2017a).

Such considerations indicated complex interactions between institutions, politics, and the productive structure in a way that would jeopardize the initial goal. This, in turn, deepened the validity of the suggested divergence between the strong version of the rule of law hypothesis and the economic complexity agenda. Additionally, the Brazilian experience at the beginning of the XXI century had proven that there was no automatic relation between the complexity of national production and inclusive growth. Actually, the dynamic resulted in a simultaneous skewing and upward shifting of the wage distribution, both a consequence of higher employment creation in low productivity sectors. On the supply side, this income growth at the bottom of the distribution was corresponded by an increase of the non-tradable prices and the share of high-tech imports from Asia (especially from China): complexity was coming from abroad while more inclusive institutions were being erected (RUGITSKY, 2019). Indeed, this disequilibrium between the increase in demand and the lack of engagement in more complex sectors was responsible for setting one of the limits for the continuity of the growth spurt (BRENCK; CARVALHO, 2019; HARTMANN et al., 2017b), but it shed light to the need of more flexible reasoning to connect both complexity and inclusiveness. After all, it could be that the productive structure was not such a "high definition" reflection of those social features (HARTMANN et al., 2017a).

If there were still many factors that had to be better addressed for contrasting both theories, the Brazilian political scene outside academia was an additional motivation since it was increasingly influenced by new paints of pro-market thoughts. The political movement that was seen by Acemoglu and Robinson as responsible for building inclusiveness ended up being considered as representative of particular interests. Consequently, the public debate was increasingly keen on a broader scope for market institutions and horizontal policies. Bolsonaro's election in 2018 strengthened an even more radical defense of market liberalization than what was advocated in Latin America during the Washington Consensus prevalence. Finally, who once was the leader of the São Bernardo's strikes, Lula, was arrested by more than a year and the day of his release coincided with the second qualifying exam of this thesis. Whereas the initial goal to contest those liberal postures became less likely to be achieved, it seemed even more needed.

Facing the difficulties of finding a significant contribution to this dispute, the following is a narrower approach to understanding the relationship between those two development strategies. Mostly, it tries to figure out what was the impact that market-oriented policy changes had on the productive structure as measured by the product space approach. The two following chapters are independent of each other. Whereas the first tries to

1 There has been some evidence on the relevance that employment (beyond the output composition) in more complex activities have for higher growth prospects (FELIPE; MEHTA; RHEE, 2014; GALA et al., 2018). 
accomplish a panel data assessment of the relation between these two approaches for economic development; the second one proposes a new instrument for analyzing trade policies by connecting data from the Observatory of Economic Complexity with tariff information from the Trade Analysis Information System (TRAINS) from the United Nations. Nonetheless, none of those exercises achieved robust conclusions, since most of the results were not sustained across different specifications - in the case of the first chapter - or indicated relations that could not be understood as causal - as for the second one. Therefore, the stars indicated below seem to shine with little confidence, but they do point to interesting directions that should be better understood.

The panel data approach used in Chapter 1 relates the product space methodology with two other different strands of research, one focused on the impact of liberalization policy and another about the diversity of the exported baskets, initially proposed by Imbs and Wacziarg (2003). As to identify liberalization episodes, it was used two indexes built by Sachs and Warner (1995), analyzing a broad sample of countries, and Li (2004), which focus exclusively on developing ones. While the former comprises information for different aspects of economic policy, ranging from tariffs to not being classified as a socialist economy, the latter considers only data relative to tariffs. Nevertheless, each one indicates a change towards a more pro-market orientation, which was the crucial aspect as to consider them both as possible robustness checks for one another, as done in Ju, Wu and Zeng (2010). Sachs and Warner's index was used in a greater extent because it includes a greater number of countries and has been used to identify the impact of liberal policies in a broader scope of outcomes. Inclusively, it was interpreted by Giavazzi and Tabellini (2005) as responsible for capturing a political reorientation that reached farther than international trade. From those exercises, what comes out as most interesting is the heterogeneous impact of liberalization, depending on the stage of development. The institutional convergence pointed by Sachs and Warner seems to be either neutral or have adverse effects on developing countries' product space. However, this conclusion was also not robust through all specifications.

At last, Chapter 2 studies the Brazilian liberalization process of the early 1990s using tariff data at the industry level. It tries to relate how measures in the product space behaved during those years and connect them with this crucial policy instrument. However, what was achieved had more to say about the usage of the product space methodology than with liberalization policy in itself, since the econometric analysis indicated a spurious relation between tariffs and the density measure. Therefore, its contribution has two main directions: one is bringing those two datasets together from OEC and TRAINS, and the other is raising an alert about the density measure's interpretations. 


\section{Resumo}

O espaço de produtos, junto com as medidas da Economia da Complexidade, fornece uma abordagem que possibilita renovar linhas de pesquisa dedicadas a posicionar a composição setorial do produto no centro das formulações sobre desenvolvimento econômico. Tal perspectiva, entretanto, é contraposta por outras escolas de pensamento cujo foco está na relevância do funcionamento de instituições de mercado, para as quais o comércio internacional exerce um papel crucial. Assim, esse estudo visa analisar como o impacto de políticas orientadas por essa segunda perspectiva podem ser compreendidas pela metodologia do espaço de produtos. No Capítulo 1 são executados três exercícios empíricos de comparação entre países para identificar como liberalização comercial afetou medidas de complexidade do espaço de produtos. Contudo, os resultados não mostram um impacto robusto de tais políticas sobre essas medidas. Há evidências de alguma heterogeneidade entre níveis de renda quando consideramos a interação entre políticas e a estrutura produtiva, mas ela tampouco se mostrou robusta a diferentes especificações. Já no Capítulo 2 é proposta uma base de dados que conecta a série de comércio construída pelo Observatório de Economia da Complexidade com dados sobre tarifas fornecidos pelo Sistema de Informação e Análise do Comércio da ONU (TRAINS) para compreender o impacto de mudanças em políticas tarifárias sobre as capacidades dos países. O exercício empírico foca no processo de liberalização brasileiro nos anos 1990s. Resultados sugerem que, embora o Brasil tenha aumentado a diversidade de suas exportações logo após o corte de tarifas no início da década, ele não foi capaz de ganhar relevância em atividades associadas com capacidades diferentes daquelas para as quais já possuia vantagem comparativa.

Palavras-chave: Economia da Complexidade, Política Comercial e Desenvolvimento, Reformas de Liberalização

JEL: F14, O19, O24 


\section{Abstract}

The product space, along with the Economic Complexity measures, provides a data driven approach aimed to renewal the strands of though that posed the sectoral composition of output at the center of their concerns on development. Such view, however, has long been opposed by other branches of research focused mainly on the relevance of sound market institutions, for which openness to trade has had a crucial role. Therefore, this study aimed at analysing how the impacts of policy measures oriented by this latter perspective could be understood by the product space methodology. In Chapter 1 three empirical exercises are performed using cross-country analysis as to identify how trade liberalization policies affected complexity and product space measures. Results do not show a robust effect of this policy orientation, though. Some heterogeneous effects between levels of income do seem to be relevant to understand the interaction between liberal policies and the productive structure, but it was not robust for different specifications. As for Chapter 2, it is proposed a dataset that connects the trade series constructed by the Observatory of Economic Complexity with the UN Trade Analysis Information System as to understand how tariffs impact capabilities as measured by the product space. The empirical exercise focus on the Brazilian liberalization process in the 1990s. Results suggests that, although Brazil raised its diversity of exports right after its tariff cut in the early 1990s, it was not able to engage in industries that had different capabilities from the ones it already presented comparative advantage.

Key-words: Economic Complexity, Trade Policy and Development, Liberalization Reforms

JEL: F14, O19, O24 


\section{List of Figures}

1 Relation between income, Theil Index and ECI . . . . . . . . . . . . . . 22

2 Theil Index and ECI for selected countries . . . . . . . . . . . . . . . 23

3 Composition of the 100 more complex goods by group . . . . . . . . . . . . 25

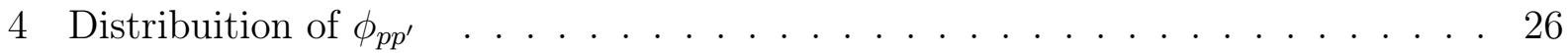

5 Proportion of liberalized economies per income level . . . . . . . . . . . . . . . . 29

6 Economic complexity before and after liberalization episodes . . . . . . . . . . 30

$7 \quad P \tilde{C} I, \tilde{\omega}$ and liberalization $\ldots \ldots \ldots \ldots \ldots \ldots$

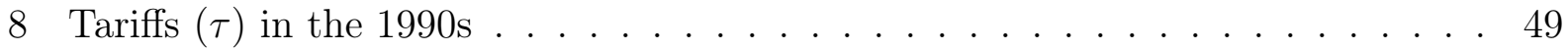

9 Measures for the Brazilian productive structure . . . . . . . . . . . . . . . . 50

10 Brazilian $P \tilde{C} I(\mathrm{RCA})$ by decade . . . . . . . . . . . . . . . 51

$11 \beta_{\phi}$, t-statistics and number of products per quantile . . . . . . . . . . 55

\section{List of Tables}

1 Liberalization and Complexity measures . . . . . . . . . . . . . . . 33

2 Interaction between reforms and income . . . . . . . . . . . . . . . . 35

3 Average $P \tilde{C} I$ and $\tilde{\omega}$ for "shoots" and "shots" after liberalization . . . . . . . . . . 37

4 Interacting SW's index with density . . . . . . . . . . . . . . . . 40

5 Income heterogeneity . . . . . . . . . . . . . . . . . . 4 41

6 Density and tariff reduction $\left(95^{t h}\right.$ percentile distance $) \ldots \ldots \ldots$. . . . . . 54

7 New exports $(\mathrm{RCA})$ before $1994 \ldots \ldots \ldots \ldots \ldots$. . . . . . . . . . . 57 


\section{Contents}

1 HOW LIBERALIZATION IMPACTS ECONOMIC COMPLEXITY? 15

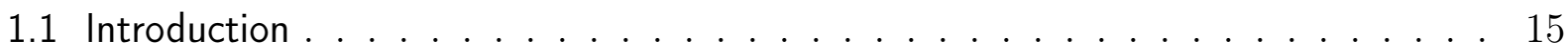

1.2 Related literature . . . . . . . . . . . . . . . . . . . . 16

1.3 Empirical framework . . . . . . . . . . . . . . . . . . . . . 24

1.4 Liberalization and the productive structure . . . . . . . . . . . . . . 27

1.4.1 Impact on diversity and complexity . . . . . . . . . . . . . . . . . . . 29

1.4.2 Understanding shoots and shots . . . . . . . . . . . . . . . . 35

1.4.3 Liberalization and unrelated activities . . . . . . . . . . . . . . . 38

1.5 Discussion . . . . . . . . . . . . . . . . . . . . . . . . . 42

2 CONNECTING TARIFF POLICIES TO THE PRODUCT SPACE 45

2.1 Introduction . . . . . . . . . . . . . . . . . . . . . 45

2.2 The liberalization process . . . . . . . . . . . . . . . . . 47

2.3 Brazilian product space in the 1990s . . . . . . . . . . . . . . . . . . . . 49

2.4 Data . . . . . . . . . . . . . . . . . . . . . . . 51

2.5 Impact of tariff reduction . . . . . . . . . . . . . . . . . . . 52

2.6 Commentaries . . . . . . . . . . . . . . . . . . . . . . 58

$\begin{array}{ll}\text { APPENDIX } & 60\end{array}$

APPENDIX A - ECI MEASURE AND SAMPLES . . . . . . 61

A.1 Economic and Product Complexity Indexes . . . . . . . . . . . . . . . . . . . . . 61

A.2 Sample for Chapter $1 \ldots \ldots$. . . . . . . . . . . . . . . . . . . 62

A.3 Additional sample Section $1.4 .3 \ldots \ldots \ldots$. . . . . . . . . . . . . 62

APPENDIX B - METHODOLOGY . . . . . . . . . . 63

B.1 Connecting tariffs and the SITC codes . . . . . . . . . . . . . 63

$\begin{array}{ll}\text { BIBLIOGRAPHY } & 70\end{array}$ 


\section{How liberalization impacts economic com- plexity?}

\subsection{Introduction}

Trade policies have been an usual subject in the news during recent past years, it ranges from the Trans-Pacific Partnership in 2016 to the recently ended trade war between the US and China, including the final agreement on free trade between the European Union and the Mercosur. Kristalina Georgieva, the IMF's Managing Director, has chosen trade barriers reduction and global markets integration as top priorities to be addressed by the Fund in the following years ${ }^{1}$. Even though the impacts of trade liberalization on economic performance have already been much debated ${ }^{2}$, there are still many aspects to be better understood about how those policy changes impact on one's nation productive structure. This study aims to use the product space approach (HIDALGO et al., 2007) and Economic Complexity measures (HAUSMANN; HIDALGO, 2014) for assessing such relations through some empirical exercises using liberalization indexes first proposed by Sachs and Warner (1995) and Li (2004) which were later updated.

So far the economic complexity research agenda has taken a data driven approach focused on understanding if and how these measures of exports are related to social and economic dimensions. After the work from Hidalgo et al. (2007), that has shown how a nation's product space tells much about its stage of development, the construction of the economic complexity index enabled empirical works to relate concerns about the productive structure to relevant features for development such as speeding up convergence (GALA; ROCHA; MAGACHO, 2018) and lowering inequality (PINHEIRO et al., 2018; HARTMANN et al., 2017b). However, this literature has scarcely investigated the relation between product space's behavior and concrete policy measures. Theoretical models have been designed as to better understand how some empirical regularities can emerge from agents' behavior (FREIRE, 2019; FERRARINI; SCARAMOZZINO, 2016), however they keep the trade policies factor out. In this perspective, the work from Boschma and Capone (2015) is one noteworthy exception, since they use institutional classification by the variety of capitalism literature as to understand how developed countries' product spaces evolved differently according to their institutional arrangements.

On the other hand, another similar strand of the literature focused on export diversification has already gone deeper to investigate the relation of such feature to economic

1 Document available at:

https://www.imf.org/en/Publications/Policy-Papers/Issues/2019/10/16/am2019-gpa-101719

2 See Wade (1990) for a critical review on the early evidence of the impacts of liberalization on economic growth. 
policies, specially liberalizing ones. Imbs and Wacziarg (2003) was the first study to show an inverse U-shaped relation between the diversity of the economic activities undertaken in a given country and income per capita. Similarly to the Kuznet's findings on the sectoral composition of output during the development process, Wacziarg and Imbs indicate that branches of activities would first diversify as the nation became richer and would then concentrate after a given level of wealth. Interestingly, the descending phase of diversification was usually anticipated if the country had a relative larger chain of commerce. Empirical evidence, however, has not shown unilateral results of this relation between openness to trade and diversification, while some studies have found negative impacts of liberalization on the exports diversity (AGOSIN; ALVAREZ; BRAVO-ORTEGA, 2012), others found positive influence (MARTINCUS; GóMEZ, 2011; OSAKWE; SANTOS-PAULINO; DOGAN, 2018), and others, still, found that the impact of reforms varied according to the political regime (MAKHLOUF; KELLARD; VINOGRADOV, 2015). Notwithstanding, the research on export diversification has already investigated more aspects of foreign trade and has much to contribute to the economic complexity agenda as proposed by Hidalgo et al. (2007).

This study, therefore, uses a revised and updated classification of liberalization episodes from Wacziarg and Welch (2008) - for a broad set o countries - and from Ju, Wu and Zeng (2010) - for only developing ones - as to understand how those episodes were responsible for changes in the productive structures as measured by the economic complexity indexes. The remainder of this text is divided as follows. Next section provides a literature review on some empirical regularities documented by both the economic complexity and the export diversification literature relating productive structure to social and economic aspects. Then, after presenting some measures used for the product space analysis, some empirical exercises are conducted to assess how liberalization episodes impacted them. As far as the regressions conducted by this study are concerned, liberalization reforms did not have a robust impact on product space measures, since results from different analysis point to different directions. Nonetheless, there were some evidence of heterogeneous effects for different levels of income.

\subsection{Related literature}

Convergence can be achieved by all countries, even those with low initial levels of skills, as long as they are open and integrated in the world economy. Sachs and Warner (1995)

Liberalization policies have already been both fiercely defended and considerably questioned in Latin America during the last 30 years. After its prestige expressed in the Wash- 
ington Consensus ${ }^{3}$ (1989), it had a lateral position in the public debate during the leftwing governments in the beginning of the XXI century, but now returned at full strength for some cabinets in the region, as is the case for Brazil. Although Jeffery Sachs seems to have adopted nuanced opinions on the subject, being much less enthusiastic then he was when wrote the epigraph ${ }^{4}$, his study with Andrew Warner in 1995 (hereafter called by SW) became an influential one favoring liberalization policies (SACHS; WARNER, 1995). It analysis the link between openness and development and poses the end of the twentieth century as a time of support for those policies just comparable to the decades before the First World War ${ }^{5}$.

One of the reasons for the study to be highly mentioned is its contribution to empirical research on liberalization by constructing an index to identify the implementation of more liberalized trade policies from 1950 up to the 1980s. Trade, actually, had a broader interpretation and was taken as the tip of the iceberg for identifying the adoption of promarket economic institutions ${ }^{6}$ Indeed, their interpretation was later backed by Giavazzi and Tabellini (2005) that found a positive correlation between SW's variable and other institutional (corruption and property rights) and macroeconomic (public deficit and inflation) measures. Such connections led Giavazzi and Tabellini to understand the index in a broader sense as responsible for capturing reforms that extended "the scope of the market, and in particular of international markets"7 (GIAVAZZI; TABELLINI, 2005, p. 1298).

Both studies found empirical evidence for a positive effect of greater market integration on growth. Giavazzi and Tabellini (2005), actually, go even further and assess that liberalizing reforms on the economic sphere were more favorable to development than political ones - defined as those responsible for setting up liberal democracies. Such conclusions, however, were not exhaustive on the empirical research. Even Wacziarg and Welch (2008) (henceforth WW), that revised and updated the SW's index so it could span up to the first years of the XXI century, did not find a positive impact of liberalization on growth when the 1990s were included - at least not in a pool of cross sections regression. They did find, however, a positive effect when using within estimators to assess the impact of

3 For a review on the enthusiasm about liberalism in the 1990s see Williamson (2008).

4 In his book The age of sustainable development (SACHS, 2015) liberalization appears as a minor element for development, after innovation and productivity enhancing technologies.

5 It is rather interesting that writers such as Karl Polanyi had discussed a causal relation between the First Great War and the over-liberalized period that precede it.

6 "Trade liberalization not only establishes powerful direct linkages between the economy and the world system, but also effectively forces the government to take actions on the other parts of the reform program under the pressures of international competition" (SACHS; WARNER, 1995, p. 2). It was certainly not a novelty, even back in the 1990s, the idea that international integration, when accompanied by pro-market orientation, was an effective manner to constrain national or particular groups interests in the name of market efficiency.

7 Rodríguez and Rodrik (2001) had already pointed this interconnection of reforms as a relevant issue of endogeneity, if the index was to be considered as responsible for only assessing causal impacts of trade openness. 
the reforms on growth, investment rates and volume of trade considering a period that ranged from 1950 to 1999. After analysing the reforms on selected countries their conclusion rejects the existence of a "one-size-fits-all" model, despite still being favorable to outward-oriented policies. Billmeier and Nannicini (2013) is also less enthusiastic about liberalization reforms as measured by the SW's index as they find results in multiple directions using a synthetic control approach ${ }^{8}$. The fact that it was harder for latecomers to take advantage from liberalization, leads the authors to propose a kind of "low hanging fruit" hypothesis for the impact of the reforms. It would be crucial for developing countries to have moved first in the undertaking of liberalization measures if it was to compete both on the exports of similar labor intensive products and in the attraction of a given stock of capital for foreign investments. However, Figure 5 in Section 1.4 below shows that the timing of adopting liberalized policies was also related to income itself, what mixes up the causation understanding of the reforms.

Such examples contradict the convergence hypothesis in the epigraph stated by Sachs and Warner that were then more confident where policies should aim to: "we find no cases to support the frequent worry that a country might open and yet fail to grow" (SACHS; WARNER, 1995, p. 44). Their argument relied beyond the productivity gains from trade based on exploring comparative advantages, but also claimed liberalization was responsible for accelerating structural change: liberalized economies ${ }^{9}$ had a faster growth of the industrialized products' share in the export basket. Disregarding that the countries included in such definition were substantially different from the others ${ }^{10}$, also recent studies focused on the impact of pro-market reforms on the diversification of exports were much less conclusive about this structural change effect.

Martincus and Gómez (2011), for instance, found favorable evidence for SW's argument and identified that the mutual tariff reduction implemented by the United States and Colombia enhanced the diversification of Colombian exports. The effect was statistically significant both when regressing the number of exports against average tariffs and when considering the probability of a given product being exported using data on the industry level. However, it was a one country analysis which had the intent to suggest what would be the net impact of adopting a free trade agreement with the US and not a wide open trade policy. As for a panel data assessment, Osakwe, Santos-Paulino and Dogan (2018) also found that lower tariffs and greater volume of trade were related with higher diversification (measured through the Theil Index for exports) considering 144 develop-

8 One should notice that the test is sometimes based on doubtful comparisons, despite their concerns in the construction of the control groups. For instance, the donor pool of countries in Latin America to be compared with Mexico (one of the few with positive impact from the reforms for all placebo tests) are Venezuela, Costa Rica and Haiti. The substantial differences in the economic, historical and social spheres should raise additional concerns on comparisons like this.

9 Here restricting the liberalization status to those countries that matched their criteria at least since 1970.

10 The human capital index from the Penn World Table for 1970 was $57 \%$ higher for countries considered to be in this early liberal group in relation to those excluded. 
ing countries. At last, Makhlouf, Kellard and Vinogradov (2015) finds a positive relation between greater trade relative to GDP and diversification of exports for developing countries, but their results indicate that this relation holds only for democracies instead of being widespread. The mechanism suggested for reasoning this finding relates to the fact that under democracies there would be a broader set of opportunities to entrepreneurs after expanding the market, while autocracies would channel benefits to more restricted groups.

Although it goes beyond the scope of this study, the political economy of liberalization reforms is much debated along the understanding of the reforms themselves. Besides the work from Giavazzi and Tabellini, also Sachs and Warner identified that countries with a greater labor to land ratio had a greater probability of adopting pro-market reforms. This could be understood by a Hecksher-Ohlin model in which labor would benefit from opening since it was the most intensive factor of production and, therefore, a government concerned with the majority of the population should back such reforms.

Other studies, nonetheless, have found either mixed or negative impacts of the reforms on trade measures. Ju, Wu and Zeng (2010) uses both the SW's index and another one from Li (2004) - that considers only tariff cuts for 39 developing countries - to assess the impact of liberalization on the trade balance, but does not consider the composition of the traded basket. Their findings are consistent across several specifications to show that both the volume of imports and exports are greater after liberalization reforms. Notwithstanding, the impact on the trade balance is much less clear since it does not show statistical significance in any regression for the reduced sample and only in some specifications points to a worsening effect for a broader set of countries included in SW's index. As for Agosin, Alvarez and Bravo-Ortega (2012) the results show a negative relation between liberalization - also identified through SW's updated variable - and diversification of exports, contradicting the findings in Osakwe, Santos-Paulino and Dogan (2018), even though it uses a more restrict panel of countries. In this case the composition of exports is measured not only by the Theil Index, but also by the Gini and the Hirschman-Herfindahl coefficients, and all of them point to a greater concentration after liberalization reforms in a system GMM estimation. It is interesting to remark their assessment of no impact on the diversity of exports after financial reforms, measured by an index from Bekaert, Harvey and Lundblad (2005) that indicates the first year of liberal policies for finance regulation. The linkage between access to the capital market and diversity of output was suggested by Imbs and Wacziarg (2003) as one mechanism that could explain the U-shapped path of sectoral concentration along development. If diversity resulted from an portfolio reasoning to invest in different sectors as to lower risks - not putting all eggs in one single basket - then the deepening of financial markets, as the country got richer, would eventually diminish the portfolio motives and allow to focus exclusively on comparative advantages considerations. 
The other mechanism suggested by Imbs and Wacziarg (2003) to explain the Ushapped pattern was the "interaction between productivity increases and trading costs" (WACZIARG; WELCH, 2008, p. 83). Assuming that consumption would change its composition as income rose - demanding greater diversity as suggested by the Engel's Law - then producing those different goods internally would require comparing local and foreign productivity. If trading costs had a negative linear relation to the capital stock, but productivity growth at the frontier responded to a non-linear relation and became harder to be achieved at higher levels, then a concentration process would eventually take place. Indeed, their findings showed that more open economies tended to specialize at a lower level of income, what was exemplified by Ireland, Singapore and Cyprus. Also Carvalho and Kupfer (2011) suggests that the Brazilian process of concentration could be related to the rapid liberalization process it went through during the 1990s - besides other channels such as the dutch disease or the lack of a dynamic domestic market. However those studies differ from the ones commented above as they measure diversification by the employment and value added composition, instead of considering export baskets.

It was Cadot, Carrere and Strauss-Kahn (2011) that first connected the U-shapped sectoral concentration found for employment and value added measures to the behavior of trade and reported this same trend for exports ${ }^{11}$ (using the Theil Index for diversification). Changes in diversity, as they show, were related to the entrance and exit of markets, the extensive margin, and not to a significant change in the proportion of already exported goods, the intensive margin. This movement across industries would be related to the different pace at which countries would stop producing goods they once had comparative advantage and the emergence of new products for which they just had obtained it. As development went by, physical and human capital was accumulated and allowed for the entrance in new activities. Old industries, however, would not immediately disappear from the export basket since they had front runners advantages in the processes of production, or a established relation with costumers. The exit from those industries would take place only as new countries engaged in those activities and obtained higher productivity. As to check the validity of such mechanism they compare the stocks of physical and human capital of re-concentrating and diversifying countries with the average level of those factors of production required by the industries they were engaging and exiting ${ }^{12}$. What was found is that only for re-concentrating countries there was a significant distance between their stocks and the required level of capital (both physical and human), confirming

11 One interesting disclaimer about those findings is made by Parteka and Tamberi (2013) showing that this upward end of the diversification curve is mostly driven by natural resource exporters, small economies (which were supposed to have concentrated productions) and the US (which they classify as a "distinct pattern of trade").

12 The distance between the required endowments to produce each good and a country's is obtained using a variant from the PRODY variable (HAUSMANN; HWANG; RODRIK, 2007). This is a weighted average of economic and social characteristics from the countries that export each product (see Section 2.4 for further explanation), similarly to the measures for Economic Complexity that are presented in the next section. 
their hypothesis of different timing for entrance and exit from industries. On the other hand, for all stages of development countries used to engage in industries that demanded endowments which were similar to their current stocks.

Understanding which industries can be more easily accessed by each country given its endowments or capabilities is at the center of the product space approach. Space here comprises precisely the idea that certain industries require abilities that are more related to a given set of activities than others. Hidalgo et al. (2007) illustrates it with the monkey and the forest metaphor, for which firms would be monkeys that explore different trees at a time (industries) given their capacity, while the set of all products would conform the forest. As such, this research strand goes beyond the diversity of exports, considering what are the main features of the industries that each country presents comparative advantage and to what kind of capability they are related to. The complexity measures developed by this research agenda tries to resume this understanding by expressing in one single index the interaction between the diversification of one country's exports and the rareness of the products that are being exported ${ }^{13}$ (HAUSMANN; HIDALGO, 2014). A given country will only be considered to have complex capabilities if it is able to export non-ubiquitous and diversified products; exporting only rare goods may signal naturalresource based exports, instead of a differentiation capacity, while only diversity does not guarantee complex capabilities if the country produces just the same as all others.

This measure could be understood as an empirical refinement through the network analysis of the proposition in Hausmann, Hwang and Rodrik (2007), for which future growth is related with exporting "rich countries' products" and tries to go beyond relating goods to the level of development of their relevant exporters (the already mentioned PRODY variable). The measures of complexity (ECI from the Observatory of Economic Complexity) and diversification (Theil Index from the $\mathrm{IMF}^{14}$ ), however, are strongly connected as Figure 1 shows the nonmonotone relation both had in 2005 when compared across different levels of income, measured as GDP per capita in PPP for 2011 constant international dollars (World Bank's World Development Indicators).

Both plots show a fitted second order polynomial, the first uses a sample of 118 countries and the second counts with 83 nations for which there is available data on other relevant features for a longer period later analysed in this study ${ }^{15}$. Although the two plots show a similar pattern to the one reported in Cadot, Carrere and Strauss-Kahn (2011), the reversed trend for the figure in the right is highly influenced by only three countries: Norway, Ireland and Singapore - all the three in the upper side of the Theil curve and only the first in the lower side of the ECI line. It is interesting to remark that the two last were among the early concentrated group mentioned by Imbs and Wacziarg (2003).

\footnotetext{
13 For more on the index calculation see Appendix A.1.

14 Since the ECI is a normalized index, the Theil Index was also normalized by year so they could have similar magnitudes.

15 The countries included in this study's sample are listed in Appendix A.2.
} 
Figure 1 - Relation between income, Theil Index and ECI
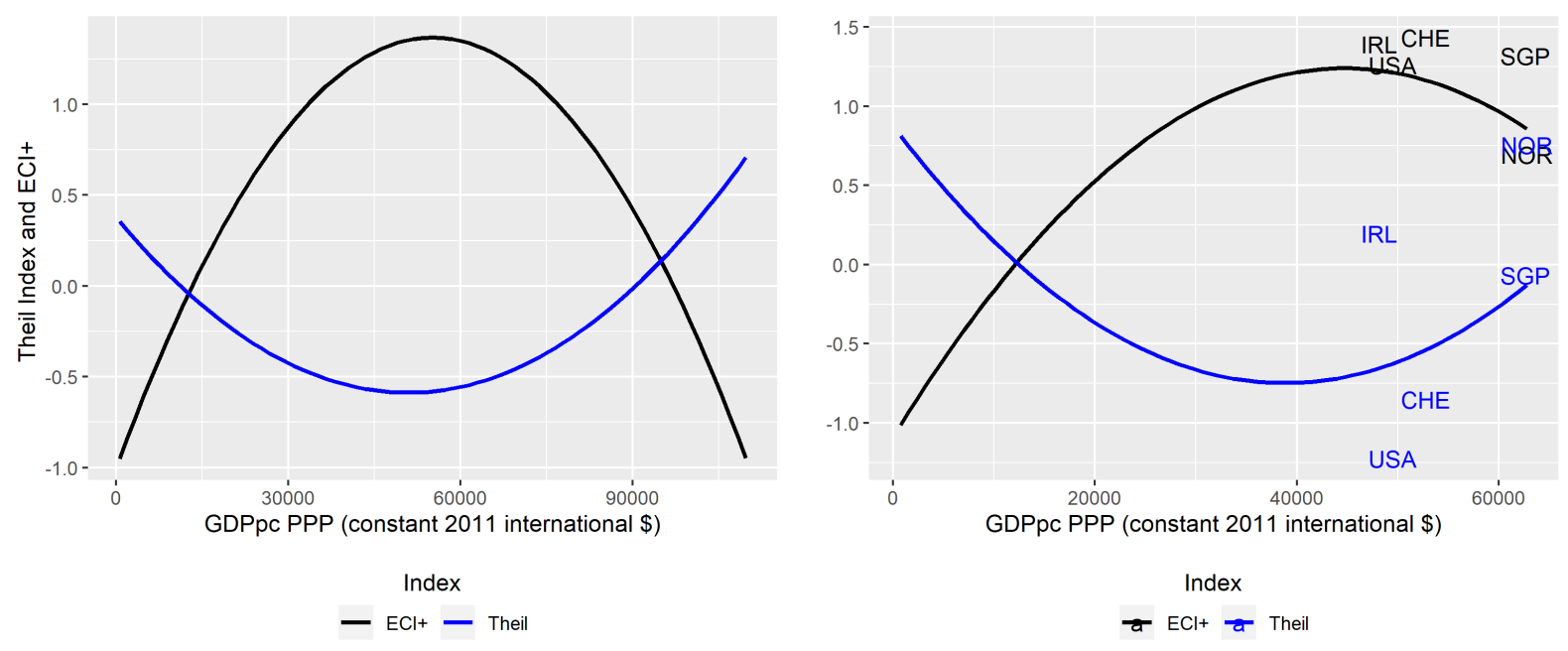

Source: Theil Index (FMI), WDI (World Bank), ECl+ (OEC). Own elaboration

Hence, as to compare how both indexes behaved for those three countries they are shown in Figure 2.

Two relevant elements should be noticed from these plots. The first is that complexity enhances the connection between economic sectoral considerations and income when compared with diversification, as it is clearly depicted for Ireland. While this was a perfect fit for the U-shapped finding in Wacziarg and Imbs' study, the ECI index presents a monotone behavior across the second half of the twentieth century. Secondly, it must be noticed the fact that the employment data used by Wacziarg and Imbs does not match perfectly the Theil index of diversification. The almost continuous sectoral concentration trend for employment in Singapore reported in their study goes on the opposite direction of the export diversification shown in Figure 2. Finally, the trend for Norway's indexes are almost entirely explained by the increasing share that petroleum had in its export basket jumping from something near to $10 \%$ in the mid 1970 s to $45 \%$ in 2005 . In fact, the export concentration on petroleum is not exclusive from Norway, among the 11 countries that had more than $50 \%$ of their export values concentrated in one single good in 2005, for eight of them this product was crude petroleum.

Just as exports diversification has been posed as a positive policy objective, since it has been shown to be related with lower output volatility and higher growth rates, economic complexity has also being linked with social and economic features relevant for social welfare. Hartmann et al. (2017a), for instance, find that economic complexity has a greater influence on the income Gini index than any other variable such as GDP per capita, institutional factors and schooling. Since complexity is itself a resulting variable from other institutional and economic features, such result suggests that this measure can better capture how the productive structure is a "high-resolution expression of a number of factors" relevant for development. Other studies have posed the complexity measure as the renewing of structuralists concerns about the relevance of the productive structure for 
Figure 2 - Theil Index and ECI for selected countries

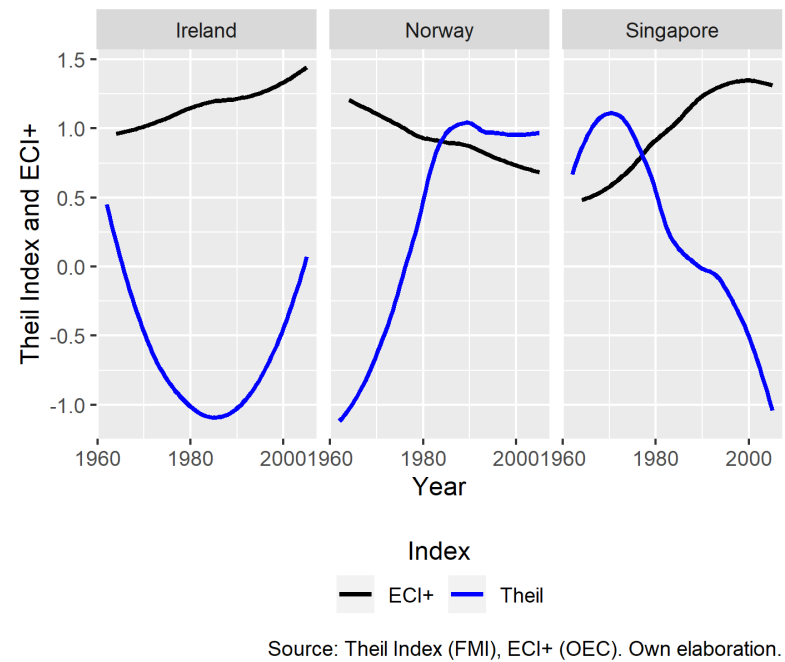

convergence. Including the ECI in growth regressions, Gala, Rocha and Magacho (2018) find that developing countries which were able to increase complexity were also those that presented the fastest convergence rates. Therefore, policies should aim at the productive structure when trying to achieve faster growth.

Beyond synthetic indexes on complexity, other studies have focused on the behavior of the product space and its relation to development. In this sense, Pinheiro et al. (2018) indicate that shooting high - which means to obtain comparative advantage in the export of products that require different capabilities than the ones currently in use - makes easier to initiate a virtuous cycle of diversification and growth. Such process, however, is mostly related with intermediate stages of income and complexity, since poorer countries would be unable to perform those leaps and already developed ones are prone to continue producing complex goods. In a sense, their conclusions contribute to the comparativeadvantadge-defying strategies (LIN; CHANG, 2012), in opposition to the following ones for which it would be recommended to first accumulate capital in already competitive sectors before entering new activities.

Boschma and Capone (2015) complements this agenda by differentiating how capable one country is to diversify its product space given its institutional arrangement. Using classification of liberal and coordinated market economies from the varieties of capitalism (VoC) literature, they find that countries do not specialize their productive structure in a different set of goods given their institutions. Nonetheless, liberal markets are more able to diversify - entering in unrelated activities - than coordinated ones. Their study, however, is restricted to developed economies - the only ones classified by the VoC literature -, opening space for questions if this relation between liberalized market institutions and the capacity to diversify holds for different levels of development. This will be later performed on the empirical analysis of this study.

In other words, the research agenda on economic complexity is focused in understand- 
ing through new measurements how to assess the relevance of the productive structure to future growth and inclusive development. If it was already mentioned the concern of the new IMF's Managing Director in deepening markets integration, it is also worth mentioning the working paper from two staff members of the Fund, Cherif and Hasanov (2019), focused on restating the relevance of industrial policies. Differently from the conclusions in Sachs and Warner, they view convergence not as a natural path after setting the correct market institutions, but rather as the result of policies oriented towards strategic structural change. Since such concerns have a renewed space among policy makers and multilateral institutions, it would be useful to understand how liberalization policies, that once and again shows its strength around the globe, have affected the productive structure. For such purpose, measures proposed by the economic complexity agenda can help enhancing the insights once given by analysing diversity of exports. Thus, next section presents some measures and concepts used for the construction of the product space which will be later used for the empirical analysis.

\subsection{Empirical framework}

Product space analysis is based on one of the main metrics used for analysing any other space: distances. Since the ability to produce any given good is understood as a demonstration of having a determined set of tradable and non-tradable capabilities, measures of distances between products are indirectly read as distances between stocks of human and physical capital, labor and institutions. Empirical measures of such relations were first presented by Hidalgo et al. (2007), which launched the notion of the product space as an instrument for analysing development and restated sectoral concerns about development on new empirical grounds.

Nonetheless, understanding how complexity measures arise can be counter intuitive since it is similar but not coincidental with previous notions of the sectoral composition of output for which manufactured products were mainly on focus. Figure 3, therefore, brings the proportion of each one of the ten most aggregated groups from the Standard International Trade Classification (SITC) of goods among the top 100 Product Complexity Index for each year. It illustrates that for most of the years a more complex product is a manufactured one. In 2005, for instance, photo and movie equipment was the top complex product in the Miscellaneous Manufactured articles group, and 56 others belonged to the Machinery and Transport classification. Despite this more predictable relation, it is worth noticing a drastic change in the general composition after 1975 when manufactured goods classified chiefly by materials had the largest proportion with 41 products and just one year later had only 19 among them. Such finding must draw some attention to how the index was constructed, since it allowed such a significant change in a short period of time.

As to differentiate products and their requirements for production, the analysis begins 
Figure 3 - Composition of the 100 more complex goods by group

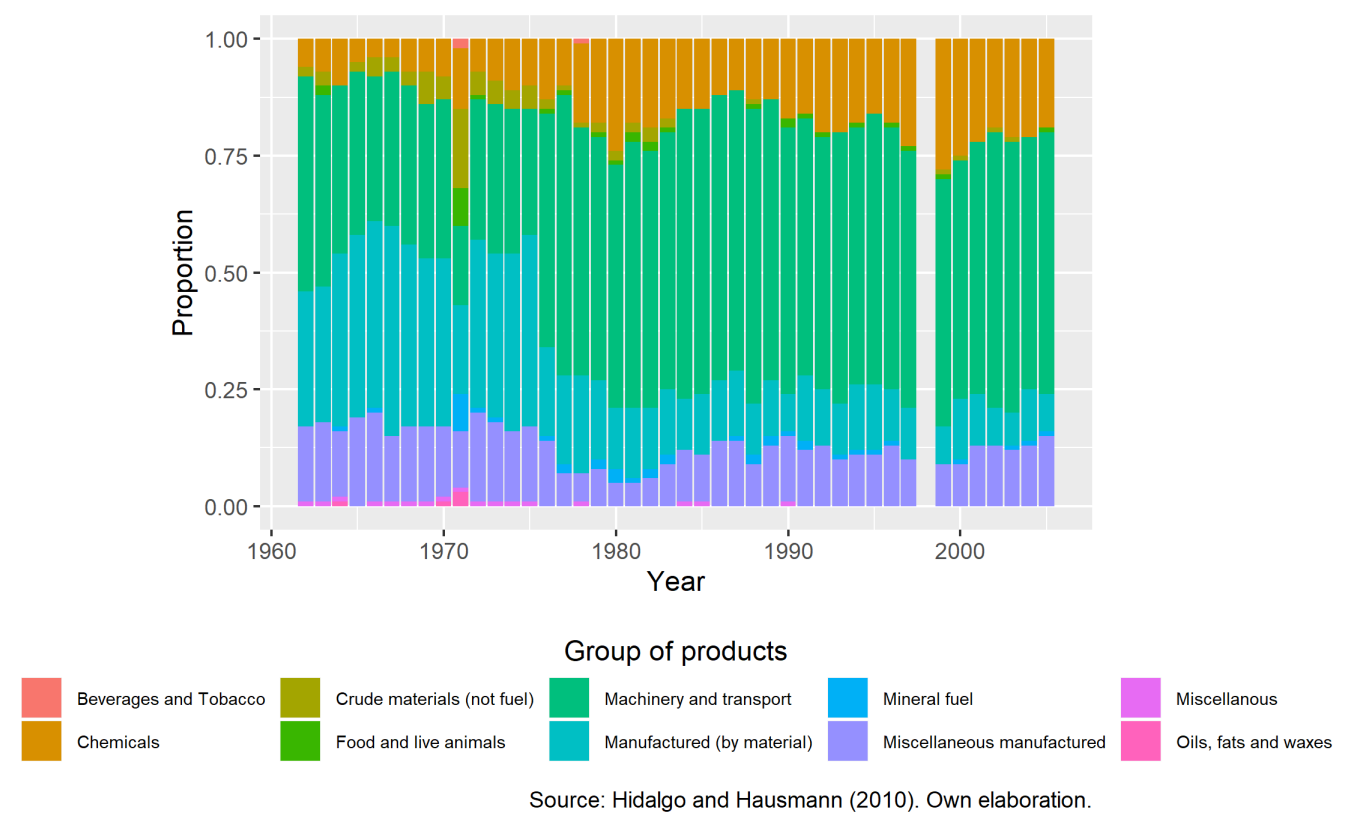

identifying which countries present Relative Comparative Advantage (RCA) in exporting each good. Following Balassa (1986), a given country $c$ has comparative advantage in product $p$ if $p$ 's share in c's exports is greater than its share in global trade. Therefore, $\mathrm{RCA}$ is defined for each year, country $(c)$ and product $(p)$ as:

$$
R C A_{c, p}=\frac{X_{c, p} / \sum_{p^{\prime}} X_{c, p^{\prime}}}{\sum_{c^{\prime}} X_{p, c^{\prime}} / \sum_{p^{\prime}} \sum_{c^{\prime}} X_{p^{\prime}, c^{\prime}}}
$$

where $X_{c, p}$ stands for the absolute value of total exports of product $p$ by country $c$. Hence, if $R C A_{c, p}$ is greater than unity, it indicates Comparative Advantage and social features of this country are, thereafter, related to product $p^{16}$. On the other way around, those products with $R C A_{c, p}$ smaller than unity represent a country's option set, denoted by $O_{c, y}$ (PINHEIRO et al., 2018). The measures of ubiquity $\left(k_{p}\right)$ - how many countries produce $p$ with relative advantage - and diversity $\left(k_{c}\right)$ - how many products are produced by $c$ with relative advantage -, like all others to come, are obtained from the analysis of RCAs: $k_{p}=\sum_{c} \mathbb{I}\left[R C A_{c, p}>1\right]$ and $k_{c}=\sum_{p} \mathbb{I}\left[R C A_{c, p}>1\right]$ where $\mathbb{I}[\cdot]$ is the indicator function that equals 1 if the condition within brackets holds true.

Finally, proximity between products $p$ and $p^{\prime}\left(\phi_{p, p^{\prime}}\right)$ for each year is defined as the minimum conditional probability of being jointly exported:

\footnotetext{
16 In this sense that these measures resemble the PRODY variable.
} 


$$
\begin{array}{r}
\phi_{p p^{\prime}}=\min \left\{P\left(\mathbb{I}\left[R C A_{c, p}>1\right] \mid \mathbb{I}\left[R C A_{c, p^{\prime}}>1\right]\right),\right. \\
\left.P\left(\mathbb{I}\left[R C A_{c, p^{\prime}}>1\right] \mid \mathbb{I}\left[R C A_{c, p}>1\right]\right)\right\} \\
\phi_{p p^{\prime}}=\frac{\sum_{c} \mathbb{I}\left[R C A_{c, p}>1\right] \cdot \mathbb{I}\left[R C A_{c, p^{\prime}}>1\right]}{\max \left(k_{p}, k_{p^{\prime}}\right)}
\end{array}
$$

This second definition considers the conditional aspect by taking into account the maximum ubiquity measure value, and therefore, undermines proximity between goods if one of them is largely produced. In other words, non-ubiquitous products (those with lower $k_{p}$ ), will show greater proximity when jointly exported with Comparative Advantage. Such weighing tries to better express the rareness of capabilities needed for those productive processes. Proximity, as defined above, yields zero for most of the relations, as can be seen in Figure $4^{17}$.

Figure 4 - Distribuition of $\phi_{p p^{\prime}}$

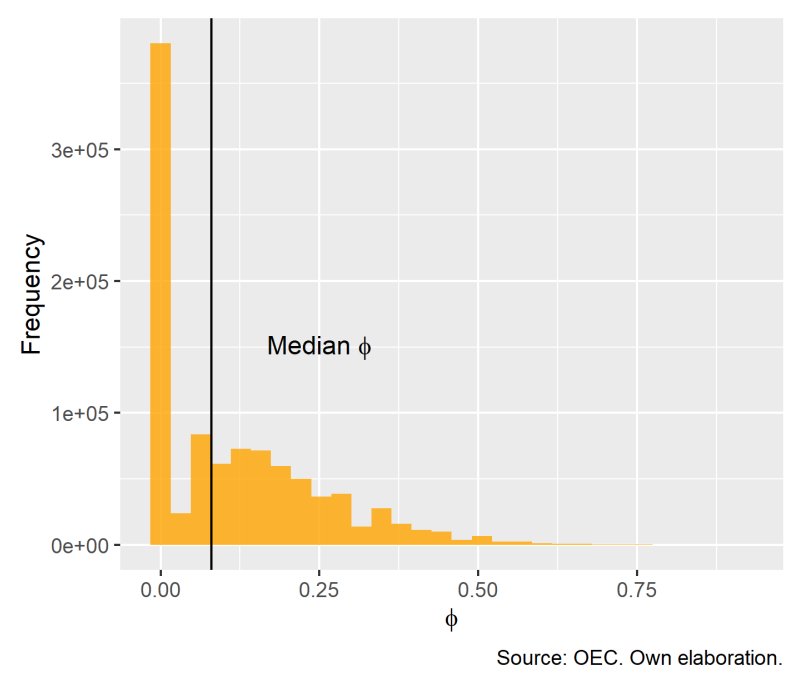

However, another concept is required as to empirically account for a country's difficulty of moving across the product space through time, since it needs to measure if current capabilities of country $c$, when jointly considered, are more or less favorable for the entrance in the production of any given product $p$. This measure is called density $\left(\omega_{p}^{c}\right)$ and for each year it is constructed by:

$$
\omega_{p}^{c}=\frac{\sum_{p^{\prime}} \mathbb{I}\left[R C A_{c, p^{\prime}}>1\right] \cdot \phi_{p p^{\prime}}}{\sum_{p^{\prime}} \phi_{p p^{\prime}}}
$$

Since countries with a more diversified economy would always show greater density values, Pinheiro et al. (2018) presented the relative density $\left(\tilde{\omega}_{p}^{c}\right)$ as to make possible cross-country comparisons by normalizing each countries density and Product Complexity $(P \tilde{C} I)$ measures by their respective option sets:

17 This is the $\phi_{p p^{\prime}}$ distribution for the year of 1979, the one in which only 34 products have no country with RCA greater than unity. On the opposite side, in 1969 this number raises to 302 products. 


$$
\tilde{\omega}_{p}^{c}=\frac{\omega_{p}^{c}-\bar{\omega}_{O_{c, y}}}{s d\left(\omega_{O_{c, y}}\right)}
$$

In other words, suppose that a given country produced all goods with Comparative Advantage, then it would have $\omega_{p}^{c}=1$ for all $p$. Since this is not the case for any country, its productive structure gets less dense in relation to a given product $p$ if the goods it produces with comparative advantage are distant from $p$ (have lower $\phi_{p p^{\prime}}$ ). Again, proximity here must be understood as common capabilities (broadly seen as social and economic attributes) needed to produce each good, so less dense productive structure in relation to product $p$ means not having social features related to its production ${ }^{18}$. Lastly, to put it in more concrete terms, consider the most complex product in 2005: machinery for specialized industries (SITC 7284). Now take two countries, Japan and Angola, the first had the highest ECI value in 2005, while the last was rated as $95^{\text {th }}$ and had the largest share of a single good in its total exports value (crude petroleum represented $94 \%$ of the total amount). In 2005 the Japanese density in regard with SITC 7284 was 0.245 and the Angolan was of -0.00562 , after the normalization proposed to construct the relative density measure those numbers were 1.75 and -0.52 , respectively. In words, the Japanese productive structure is much more dense in relation to the most complex good in 2005 than the Angolan.

With this framework in hands, it will be now conduced some empirical analysis on the relation between liberalization and the productive structure as measured by the metrics above.

\subsection{Liberalization and the productive structure}

Classifying an economy as liberalized or open is not a precise definition in any sense. When the indexes from Wacziarg and Welch (2008) and Ju, Wu and Zeng (2010) are compared, for instance, three countries have strikingly different classifications in the sample used for this study. Whilst China, India and Nigeria are considered as closed economies by the first, all went through some tariff reduction that included them in the second index. Also, as already mentioned, the very interpretation of the SW index has changed within the literature. At first it was seen as responsible for identifying solely trade liberalization reforms, but later it was interpreted in a more broader sense as an institutional reform towards pro-market orientation (GIAVAZZI; TABELLINI, 2005). In one way or another,

\footnotetext{
18 The reconstruction of the indexes for this study draws on Pinheiro et al. (2018) and applies the same filters over the sample. Were excluded countries with less than 1.2 million inhabitants in 2008 and also those which imports and exports summed less than US\$ 1 billion. Iraq, Chad, Macao and Afghanistan are considered to have unreliable data and were, therefore, also excluded. Countries which exports were null for $95 \%$ of the analysed goods were not considered. At last, the products taken into account should have total exports greater than US\$ 10 million per year.
} 
it has been highly used as to assess the impact of such policy objective and that is the the main goal of this empirical section.

The SW's criteria attributes the liberalized economy status for countries that did not present any of the following features after a given year: average tariff over $40 \%$ or non-tariff barriers over $40 \%$ of the traded goods; illegal market exchange rate premium of more than $20 \%$ in relation to the official rate; state monopoly in main national exports; nor, finally, being classified as socialist. The updated classification from Wacziarg and Welch (2008) shows that 46 countries opened their economies from the 1980s to the 1990s, resulting in a majority of liberalized economies in the 1990s (79 against 32) and a reversion of the 1980s situation (33 against 78). As for Ju, Wu and Zeng (2010) liberalization episodes were those when average tariff was cut by $35 \%$ or more, conditional on initial level being above $10 \%$ - by this criteria most episodes occurred during the 1990s (32 out of 39). Hence, a country is considered liberalized, and its liberalization dummy takes value equals unity, after the last episode occurred. The sample was restricted to consider data only up to the year of 2005, which is also the last year used by Billmeier and Nannicini (2013) in their synthetic control analysis of the WW's index, allowing for comparison between different approaches.

It was already pointed above that there are some endogeneity issues concerning the SW index - for instance the different level of human capital for those early liberalized. Still, there is another relevant concern about how to interpret it, since there is a clear correlation with income. Taking the World Bank's classification of income ${ }^{19}$ in 1990 (the first year for which all the 83 counties included in the sample were jointly labeled) it is noticeable not only that richer economies corresponded to the criteria earlier, but also in a larger proportion than the others, as can be seen in Figure 5. This reinforces the need to take into account heterogeneous effects in the empirical estimations, as to purge it out of the policy dummy, besides backing critics for prescribing liberalization reforms for all based on it (RODRíGUEZ; RODRIK, 2001).

Three empirical exercises will be performed next. Firstly it is verified the impact of a more liberalized economic environment on measures for export diversity and economic complexity. Results are not conclusive, since either statistical significance is not found, or it is not robust to different specifications. Still, this procedure already points to a different impact of those measures depending on the level of income. The second exercise aims at the average density and product complexity of entered and exited industries after the reforms. It was not found any significant impact on those measures after including other control variables. Finally, a third exercise interacts the liberal policy dummy with the density measure as to understand if one country was less or more able to create and maintain comparative advantage in unrelated industries after the reforms. In this

19 Since 1983 the World Bank uses four levels for classifying economies: Low, Lower Middle, Upper Middle and High. For 2019 the thresholds for each level considering GDP per capita were US\$1.025, US\$ 3.995 and US\$ 12.375 , respectively. 
Figure 5 - Proportion of liberalized economies per income level

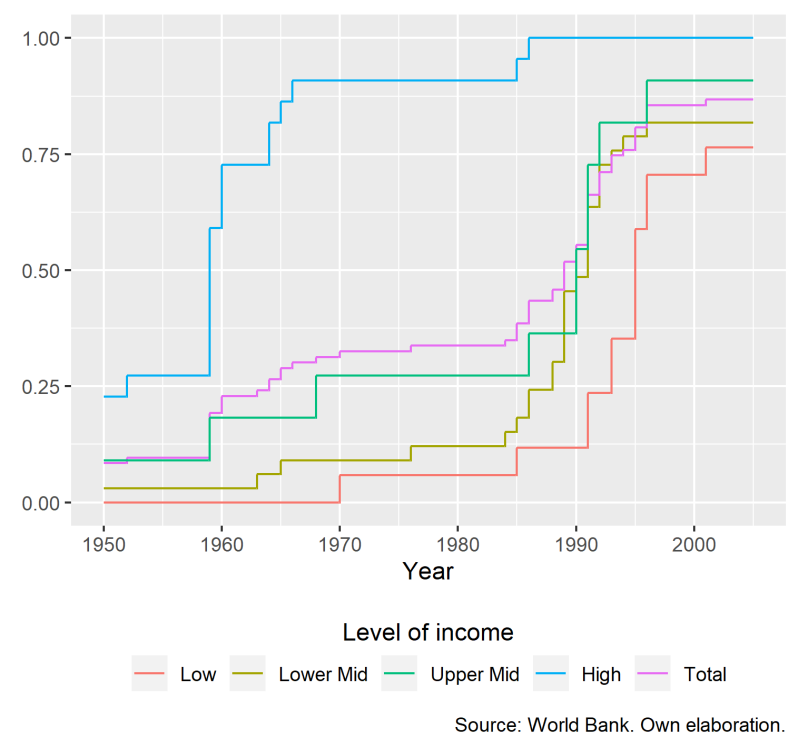

assessment liberalization seems to have a significant impact in allowing for the engagement in more distant industries for several robustness checks, but once again the heterogeneous impacts for different levels of income show a less beneficial result for developing countries.

\subsubsection{Impact on diversity and complexity}

The first evidence for little or no impact of liberalizing reforms on the productive structure, as measured by both literature under analysis, is shown in Figure 6. This event study illustrates the average value of the ECI for a set of countries in a ten years window back and forward its liberalization reform. For a consistent analysis the sample was restricted to the countries that undertook reforms at least ten years after the beginning of the measures for Economic Complexity (1962), or ten years before the end of the period under analysis $(2005)^{20}$ - the same final year used by Billmeier and Nannicini for the Sachs and Warner's index. Although the average for the whole sample seems to show some increase for the ECI after the reforms, it is not a consistent trend, being significantly reversed in the following years. These movements, which would not be expected for a persistent feature such as the sectoral composition of exports, seems to be driven mostly by the sample composition. When the regions are desegregated it is easier to notice a significant stability of the complexity measure around the liberalization period. This is specially true when focusing in Africa and Latin America, the two regions for which a greater number of countries were considered, reducing variations for the average measure

20 There were 36 countries left: Ivory Coast, Cameroon, Ghana, Kenya, Morocco, Tunisia, South Africa, Zambia, Israel, Sri Lanka, Philippines, Turkey, Albania, Bulgaria, Hungary, Poland, Romania, Costa Rica, Dominican Republic, Guatemala, Honduras, Jamaica, Mexico, Nicaragua, El Salvador, Trinidad and Tobago, New Zealand, Argentina, Bolivia, Brazil, Chile, Colombia, Ecuador, Peru, Paraguay, Uruguay. 
considered. The two North American countries included in the sample, United States and Canada, are not considered in this plot because of their early opened status that leaves no margin for considering how the measures of complexity evolved before the reforms.

Figure 6 - Economic complexity before and after liberalization episodes
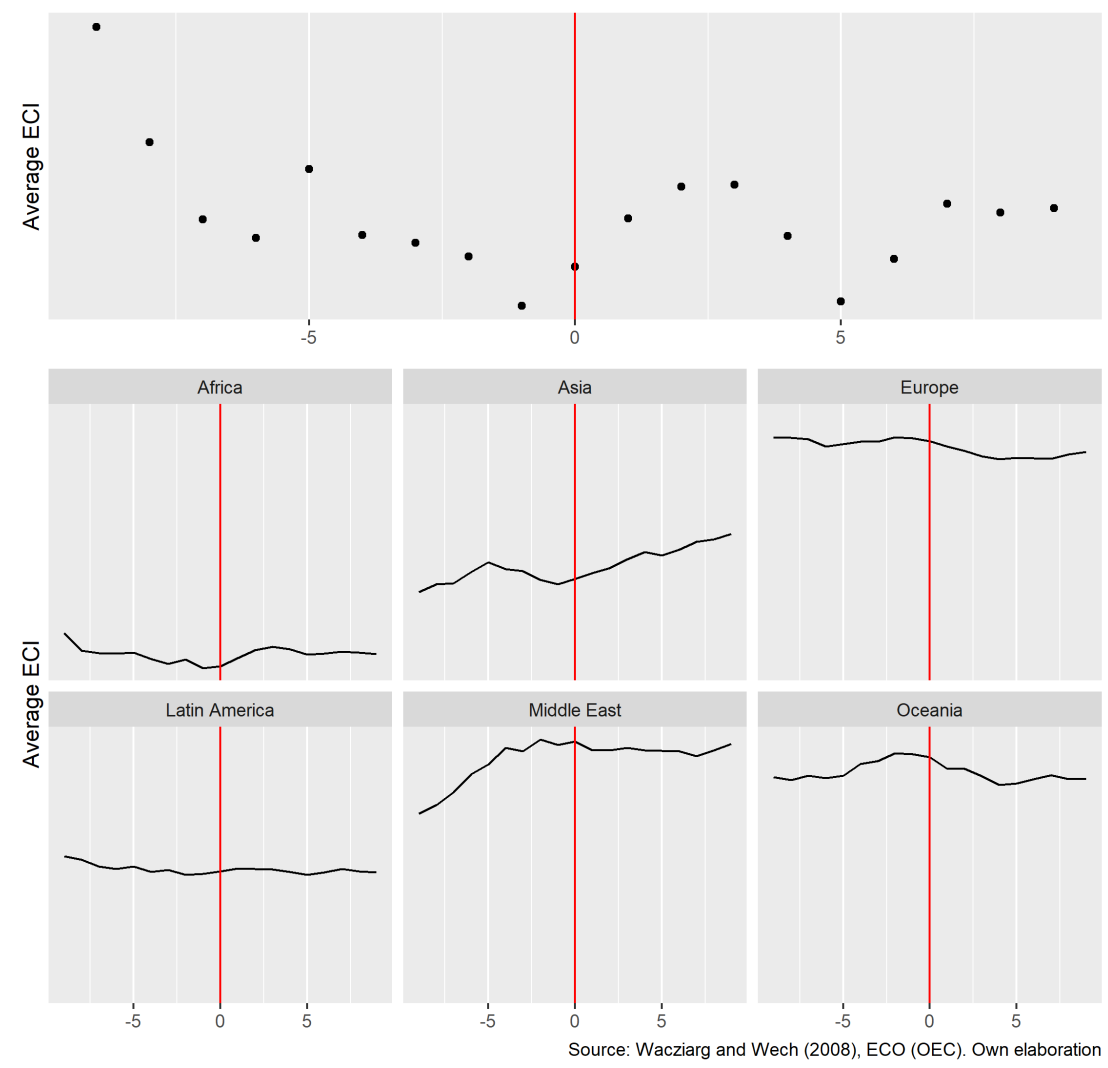

The differences in levels for each region ${ }^{21}$ is less relevant for the purpose of this analysis than the mostly stable behavior of all them around the reforms ${ }^{22}$. Neither there seems to exist a noticeable a pre-treatment trend altering the productive structure along the setting for the reforms, nor the institutional change seems to impact in any direction this measure for exports, at least in the ten years window under consideration.

Indeed, the first set of regressions reported in Table 1 point in this same direction of no impact for the reforms. Here the empirical analysis considers two different dependent variables: the Theil Index for exports from the IMF and the ECI. IMF's variable measures the level of concentration of exports and is higher for more concentrated export baskets (called as inverse diversification). It's measurement considers how distant the exports of each country is from a uniform basket, as if all countries were able to export the same amount of all products, or under a product space analysis, as if all nations were

21 The surprising similarity of the ECI for Europe, East Asia and Oceania has to due with the high index for Israel and New Zealand respectively for the last two regions. Both had complexity measures among the top 30 amidst more then 90 countries when integrated the group of liberalized nations as classified by SW.

22 The Asian case seems to be the only one that shows greater variation, however it includes only two countries (Sri Lanka and Phillipines) and has little to tell about a more broad effect. 
equally dense in respect to each good. Since it is much used in the literature of export diversification, it helps understanding the impacts of liberalization on the productive structure and comparing the results with previous works, as to later verify the consistency of those effects on complexity measures.

As to reduce noisy variation from the data and to express long term trends, all series were transformed in a five year average ${ }^{23}$ resulting in 9 different periods. This forced to introduce another filter in the data as to make it more balanced, so were excluded countries for which the ECI was not available for at least 41 years $^{24}$. The sample composition is reported in Appendix A.2, but is noteworthy that data from Ju, Wu and Zeng (2010) include only countries that went through some liberalization episode, while WW also consider countries that remained closed for the entire period. Therefore, while the former variable indicates solely changes in averages before and after the reforms, the latter also considers the comparison between countries that went through an institutional change and those that did not.

This first analysis is conducted through the usage of two different estimation methods. One was the fixed effect regressions that isolates the idiosyncratic features of each country by demeaning the endogenous variable in respect to individual averages. The second one was the system GMM as proposed by Blundell and Bond (1998) that allows treating dynamic equations with relevant path-dependent elements by incorporating serial correlation for the errors and, more importantly, instrumenting suspected endogenous variables ${ }^{25}$. This last correction is made by correlating two different transformations: differentiated series of the endogenous variables with equations taken in levels and the lagged value of the endogenous in level with the equation after being differentiated. Since the use of many internally produced instruments reduces the validity of statistical inference, the regressions reported bellow include only one lagged period for the endogenous variables and the Hansen tests for overidentification of the instruments do not present implausible p-values that could raise concern as warned by Roodman (2009). Also the regressions reported are the two-step estimators which weights units of observation using an optimal matrix derived from the residuals of the first step. This procedure is responsible for reducing the relevance in the sample of those observations with greater error variance and, therefore, reducing the parameters variance ${ }^{26}$. Finally, as for the consistency of those estimations, it is worth noticing that the Arellano-Bond test for serial correlations of second order in the residuals show valid results.

Finally, the baseline regression is a fixed effect similar to Wacziarg and Welch (2008) and tests for liberalization episodes as defined by both criteria - different data sets are

\footnotetext{
23 Excepting the first period that includes only the year of 1964 , since there was missing data for the control variables on previous years.

24 Despite this is the whole sample duration, the dataset is still unbalanced since other control variables were missing.

25 The Stata comand was developed by Roodman (2009).

26 Using the first step weighting matrix does not alter the results in any significant way.
} 
indicated as $W W$ and $Z J W$. The regression estimated in the first and the fourth column of Table 1 is:

$$
y_{c, t}=\alpha_{c}+\theta L I B_{c, t}+\epsilon_{c, t}
$$

where $L I B_{c, t}$ stands for a dummy variable that equals one if $t$ comes after the country's liberalization reform as understood by each definition and $\alpha_{c}$ is the country's fixed effect. For columns 1 to $3 y_{i, t}$ stands for the Theil Index for each country and year, and for the remaining it stands for the ECI. Other columns than 1 and 4 include control variables from the GGDC's Penn World Table (FEENSTRA; INKLAAR; TIMMER, 2015) which were selected following Pinheiro et al. (2018): an index for human capital that considers years of schooling and returns from education; a measure of income per capita taken from National Account data divided by the total population - which is also considered in a quadratic form given the relation identified in Figure 1; and a metric for capital stock per worker.

The first two regressions in columns 1 and 2 point to highly negative and significant impact of liberalization on exports concentration - meaning, therefore, it would increase diversification. Also the coefficient's magnitude remains quite similar between both regressions and would play in favor of Osakwe, Santos-Paulino and Dogan (2018) findings, but now in a sample that is not restricted to developing nations. However, the coefficient looses its significance and decreases significantly in the third column that reports the system GMM estimation. Here all variables excepting the policy and period dummies (one for each five years) were considered as endogenous for the estimation, being therefore instrumented by the transformations described above. Since the development process encompasses the accumulation of all these features under analysis it was considered best to treat them all as possibly correlated with the error term responsible for changes in the productive structure. Finding no impact for the policy dummy on diversification differs from the result found in Agosin, Alvarez and Bravo-Ortega (2012) that uses a similar sample and methodology, but finds negative results. Probably the difference in the results must be due to the control variables considered and the sample composition that may differ - the authors do not specify which countries were considered in their analysis.

In regards to the ECI measure, the lack of impact from the reforms is even more pronounced since the coefficient of interest does not show statistical significance in any estimation. If anything was to be said about the regressions it would be only the fact that its magnitude is also largely reduced in the GMM estimation, as was the case with the diversification index. Therefore, when analysing the average impact for the whole sample the increased openness to trade or allowing "for a broader scope of the market" do not seem to present any impact on the complexity of the exports. This is to say that, at first sight, being more open does not enhance current capabilities through competition or access of new products and markets. Therefore, the positive impact over growth that 
Table 1 - Liberalization and Complexity measures

\begin{tabular}{|c|c|c|c|c|c|c|c|}
\hline & \multicolumn{7}{|c|}{ Dependent variable: } \\
\hline & \multicolumn{3}{|c|}{ Theil Index (WW) } & \multicolumn{3}{|c|}{ ECI (WW) } & \multirow{2}{*}{$\begin{array}{c}\text { ECI (WJZ) } \\
7 \\
\text { FE } \\
\end{array}$} \\
\hline & $\begin{array}{c}1 \\
\mathrm{FE} \\
\end{array}$ & $\begin{array}{c}2 \\
\mathrm{FE} \\
\end{array}$ & $\begin{array}{c}3 \\
\text { GMM } \\
\end{array}$ & $\begin{array}{c}4 \\
\mathrm{FE} \\
\end{array}$ & $\begin{array}{c}5 \\
\mathrm{FE} \\
\end{array}$ & $\begin{array}{c}6 \\
\text { GMM } \\
\end{array}$ & \\
\hline L.Theil & & & $\begin{array}{c}0.921^{* * *} \\
(0.0375)\end{array}$ & & & & \\
\hline L.ECI & & & & & & $\begin{array}{c}0.918^{* * *} \\
(0.0365)\end{array}$ & \\
\hline Liberalization (WW) & $\begin{array}{c}-0.378^{* * *} \\
(0.0715)\end{array}$ & $\begin{array}{c}-0.285^{* * *} \\
(0.0717)\end{array}$ & $\begin{array}{c}-0.00834 \\
(0.0504)\end{array}$ & $\begin{array}{c}0.0244 \\
(0.0357)\end{array}$ & $\begin{array}{c}0.0181 \\
(0.0370)\end{array}$ & $\begin{array}{l}-0.0001 \\
(0.0253)\end{array}$ & \\
\hline Liberalization (WZJ) & & & & & & & $\begin{array}{l}-0.0375 \\
(0.0722)\end{array}$ \\
\hline $\log ($ Human Capital) & & $\begin{array}{c}-1.749^{* * *} \\
(0.484)\end{array}$ & $\begin{array}{c}-0.569^{* *} \\
(0.235)\end{array}$ & & $\begin{array}{c}0.831^{* * *} \\
(0.208)\end{array}$ & $\begin{array}{c}0.109 \\
(0.121)\end{array}$ & $\begin{array}{c}1.525^{* * *} \\
(0.379)\end{array}$ \\
\hline $\log \left(\mathrm{GDP} \_\mathrm{pc}\right)$ & & $\begin{array}{c}-2.540^{* * *} \\
(0.710)\end{array}$ & $\begin{array}{c}-0.826^{* *} \\
(0.415)\end{array}$ & & $\begin{array}{c}0.963^{* *} \\
(0.385)\end{array}$ & $\begin{array}{c}0.827^{* *} \\
(0.335)\end{array}$ & $\begin{array}{l}-1.542^{*} \\
(0.792)\end{array}$ \\
\hline $\log \left(G D P \_p c\right)^{2}$ & & $\begin{array}{c}0.128^{* * *} \\
(0.0391)\end{array}$ & $\begin{array}{c}0.0497^{* *} \\
(0.0212)\end{array}$ & & $\begin{array}{l}-0.0402^{*} \\
(0.0213)\end{array}$ & $\begin{array}{c}-0.0388^{* *} \\
(0.0167)\end{array}$ & $\begin{array}{l}0.121^{* *} \\
(0.0491)\end{array}$ \\
\hline $\log$ (Capital Stock) & & $\begin{array}{c}0.256^{* * *} \\
(0.0975)\end{array}$ & $\begin{array}{c}0.0434 \\
(0.0923)\end{array}$ & & $\begin{array}{l}-0.0485 \\
(0.0384)\end{array}$ & $\begin{array}{c}-0.0956^{* *} \\
(0.0427)\end{array}$ & $\begin{array}{l}-0.113^{*} \\
(0.0593)\end{array}$ \\
\hline Constant & $\begin{array}{c}3.148^{* * *} \\
(0.0260)\end{array}$ & $\begin{array}{c}13.88^{* * *} \\
(2.814)\end{array}$ & $\begin{array}{c}3.639^{* *} \\
(1.496)\end{array}$ & $\begin{array}{c}0.124^{* * *} \\
(0.0150)\end{array}$ & $\begin{array}{c}-5.231^{* * *} \\
(1.638)\end{array}$ & $\begin{array}{c}-3.259^{* *} \\
(1.305)\end{array}$ & $\begin{array}{c}4.468 \\
(3.258)\end{array}$ \\
\hline Observations & 742 & 722 & 648 & 722 & 722 & 639 & 280 \\
\hline R-squared & 0.863 & 0.879 & & 0.941 & 0.950 & & 0.886 \\
\hline $\mathrm{AR}(2)$ in first diff. (p-value) & & & 0.253 & & & 0.417 & \\
\hline Hansen (p-value) & & & 0.150 & & & 0.321 & \\
\hline Countries & 83 & 83 & 83 & 83 & 83 & 83 & 32 \\
\hline
\end{tabular}

has been related with this measure for liberalization does not seem to be channeled by the transformation of the productive structure analysed through its complexity. Such conclusion could dampen the prospects of future growth after the initial benefits from the reforms that have been suggested by the literature (WACZIARG; WELCH, 2008; BILLMEIER; NANNICINI, 2013). Finally, the last column (7) reduces the sample for 32 developing countries and uses the index for liberalization from $\mathrm{Ju}, \mathrm{Wu}$ and $\mathrm{Zeng}$, but again it has no statistical significance and shows a negative coefficient.

This first set of regressions should draw the attention in regard to two different aspects, the first is the fact that there is no clear cut relation between liberalization measures, as taken from SW's much used index, and changes in the productive structure, as measured by the Economic Complexity literature. The second one, however, has to do with the necessary concerns about econometric methods for assessing relations between the Economic Complexity measures and relevant policy features, something that should be subject of further investigation.

Lastly, the analysis of coefficients associated with the control variables show mostly a better fit to what would be expected from theory and the literature discussed above. For 
both regressions reported in columns 2 and 3 human capital has a significant and negative effect over concentration and it is confirmed the U-shapped relation between income and diversity of exports through the development path, as was pointed by Cadot, Carrere and Strauss-Kahn (2011) following the earlier findings from Imbs and Wacziarg (2003). Both effects are also present in the fixed effect regression for the Economic Complexity Index, which behaves differently from the Theil Index and increases for a greater export complexity, justifying the sign switch of the coefficients. However, the human capital changes significantly in the GMM estimation and shows no statistical significance, what is unexpected given its steady relation with complexity that has been described by the literature. Two other variables show an unforeseen estimate: capital stocks and income, considering the restricted sample for developing countries. Capital stocks are measured by the Penn World Table considering investment data on several sectors and estimating an initial capital-output ratio, therefore, it would be reasonable to find that higher stocks were related with higher levels of complexity and diversity, but that is not the case for both regressions. Even though results vary both on magnitudes and significance between estimations, it is worth to point this unfamiliar result. Secondly it is also rather rare the inverse quadratic effect of income expressed in the seventh regression. Although for these 32 countries the U-shapped relation of export sophistication and income holds, it seems to be reversed after the consideration of other control variables.

A different behavior for developing countries is also captured when the policy analysis considers the interaction with income. Table 2 shows only fixed effect regressions for the interaction of the policy dummy with the World Bank's levels of income. It is interesting that the two ends of the income distribution are the ones with significant coefficients for most of the regressions and in different directions. Since the high income group is the reference one, the liberalization coefficient without interaction captures the effect for those countries and the other interactions indicate if those groups behave differently with statistical significance. Column 1 points to a greater positive impact over export diversification of liberal reforms for richer countries since it shows a greater coefficient than the one obtained in Table 1. This is reinforced in column 2 as the coefficients for the other groups become statistically significant after the inclusion of control variables and all of them have a positive sign. Those coefficients show that the reforms' impact is lower for all other groups than for richer countries and almost vanishes when low-income nations are considered.

Similar conclusions come from the analysis of the impacts on the ECI measure. First it is interesting that the coefficient associated with liberalization goes through significant increase by simply being interacted with dummies for levels of income, as can be seen comparing Tables 1 and 2. Secondly, it calls attention the fact that for the low income group the coefficient is unaltered after including control variables and shows for both regressions a net negative impact of the reforms over the complexity of exports. Taking 
Table 2 - Interaction between reforms and income

\begin{tabular}{|c|c|c|c|c|}
\hline & \multicolumn{4}{|c|}{ Dependent variable: } \\
\hline & \multicolumn{2}{|c|}{ Theil } & \multicolumn{2}{|c|}{ ECI } \\
\hline & 1 & 2 & 3 & 4 \\
\hline Lib & $\begin{array}{c}-0.534^{* * *} \\
(0.144)\end{array}$ & $\begin{array}{c}-0.748^{* * *} \\
(0.169)\end{array}$ & $\begin{array}{l}0.120^{* *} \\
(0.0496)\end{array}$ & $\begin{array}{c}0.206^{* * *} \\
(0.0432)\end{array}$ \\
\hline Lib $\times L$ & $\begin{array}{c}0.388 \\
(0.248)\end{array}$ & $\begin{array}{c}0.730^{* * *} \\
(0.253)\end{array}$ & $\begin{array}{c}-0.228^{* * *} \\
(0.0741)\end{array}$ & $\begin{array}{c}-0.288^{* * *} \\
(0.0738)\end{array}$ \\
\hline Lib $\times L M$ & $\begin{array}{c}0.101 \\
(0.148)\end{array}$ & $\begin{array}{c}0.461^{* * *} \\
(0.178)\end{array}$ & $\begin{array}{l}-0.0898 \\
(0.0588)\end{array}$ & $\begin{array}{c}-0.224^{* * *} \\
(0.0611)\end{array}$ \\
\hline $\operatorname{Lib} \times U M$ & $\begin{array}{l}0.0434 \\
(0.169)\end{array}$ & $\begin{array}{l}0.375^{*} \\
(0.201)\end{array}$ & $\begin{array}{c}0.0485 \\
(0.0657)\end{array}$ & $\begin{array}{l}-0.0456 \\
(0.0689)\end{array}$ \\
\hline $\log ($ Human Capital) & & $\begin{array}{c}-1.872^{* * *} \\
(0.475)\end{array}$ & & $\begin{array}{c}0.900^{* * *} \\
(0.209)\end{array}$ \\
\hline $\log \left(\mathrm{GDP}_{p c}\right)$ & & $\begin{array}{c}-2.698^{* * *} \\
(0.701)\end{array}$ & & $\begin{array}{c}1.020^{* * *} \\
(0.381)\end{array}$ \\
\hline $\log \left(\mathrm{GDP}_{p c}\right)^{2}$ & & $\begin{array}{c}0.141^{* * *} \\
(0.0387)\end{array}$ & & $\begin{array}{c}-0.0451^{* *} \\
(0.0211)\end{array}$ \\
\hline $\log$ (Capital Stock) & & $\begin{array}{l}0.230^{* *} \\
(0.0933)\end{array}$ & & $\begin{array}{l}-0.0307 \\
(0.0385)\end{array}$ \\
\hline Constant & $\begin{array}{c}3.157^{* * *} \\
(0.0254)\end{array}$ & $\begin{array}{c}14.65^{* * *} \\
(2.790)\end{array}$ & $\begin{array}{c}0.119^{* * *} \\
(0.0145)\end{array}$ & $\begin{array}{c}-5.586 * * * \\
(1.625)\end{array}$ \\
\hline Observations & 742 & 722 & 722 & 722 \\
\hline R-squared & 0.865 & 0.882 & 0.943 & 0.951 \\
\hline Countries & 83 & 83 & 83 & 83 \\
\hline $\begin{aligned} \mathrm{obl} & \\
* 2 & \end{aligned}$ & $\begin{array}{l}\text { andard } \\
0.01, *\end{array}$ & $\begin{array}{l}\text { ors in } \mathrm{p} \\
<0.05 \text {, * }\end{array}$ & $\begin{array}{l}\text { theses } \\
0.1\end{array}$ & \\
\hline
\end{tabular}

into account the fact that in any of the regressions the upper middle income group has indistinguishable results from the high income, it is noticeable the reforms have specially different impacts for the poorest countries. Although the results seem to be consistent for all regressions, in the system GMM estimations all coefficients for the policy dummy loose their statistical significance and it was chosen not to report them, as it would add little information.

\subsubsection{Understanding shoots and shots}

Since the general measure for Economic Complexity does not seem to be directly affected by liberalization reforms, it could be that the composition of the export basket had been impacted. Indeed, as discussed above, changes in the extensive margin are the main responsible for changes in the diversity of export baskets (CADOT; CARRERE; STRAUSS-KAHN, 2011). It would be plausible to imagine that liberalization reforms, by changing market structure and amplifying competition could alter how countries were able to move along the product space. There would be two possibilities for those changes, or countries could get even more concentrated on the production of those goods in which they already had comparative advantage; or they could take advantage from the more open economy to assimilate distant products and import inputs that were not available 
before, reaching remote positions in the product space ${ }^{27}$.

Therefore, aiming to understand how productive structure evolved after shocks, Figure 7 shows an event study for the the average relative Product Complexity $(P \tilde{C} I)$ and the relative density $(\tilde{\omega})$ for entering and exited products. The sample here is again the same as in Figure 6. The entering products, named in Pinheiro et al. (2018) as "shoots", consider those goods that were exported with Comparative Advantage by the first time in a four years range and remained as such for at least four years afterwards. While the exited products (here called by "shots") are those that made a reversed path: were produced with comparative advantage for at least four years and stopped to be in the next four. Such definition tries to take into account the great variability in export trends, considering only products that presented some resilience in their condition. Some of this volatility also comes from the fact that not all countries enter new markets - as it is here defined - every year and data is somewhat sensible to the time window chosen.

Figure $7-\tilde{P C} I, \tilde{\omega}$ and liberalization
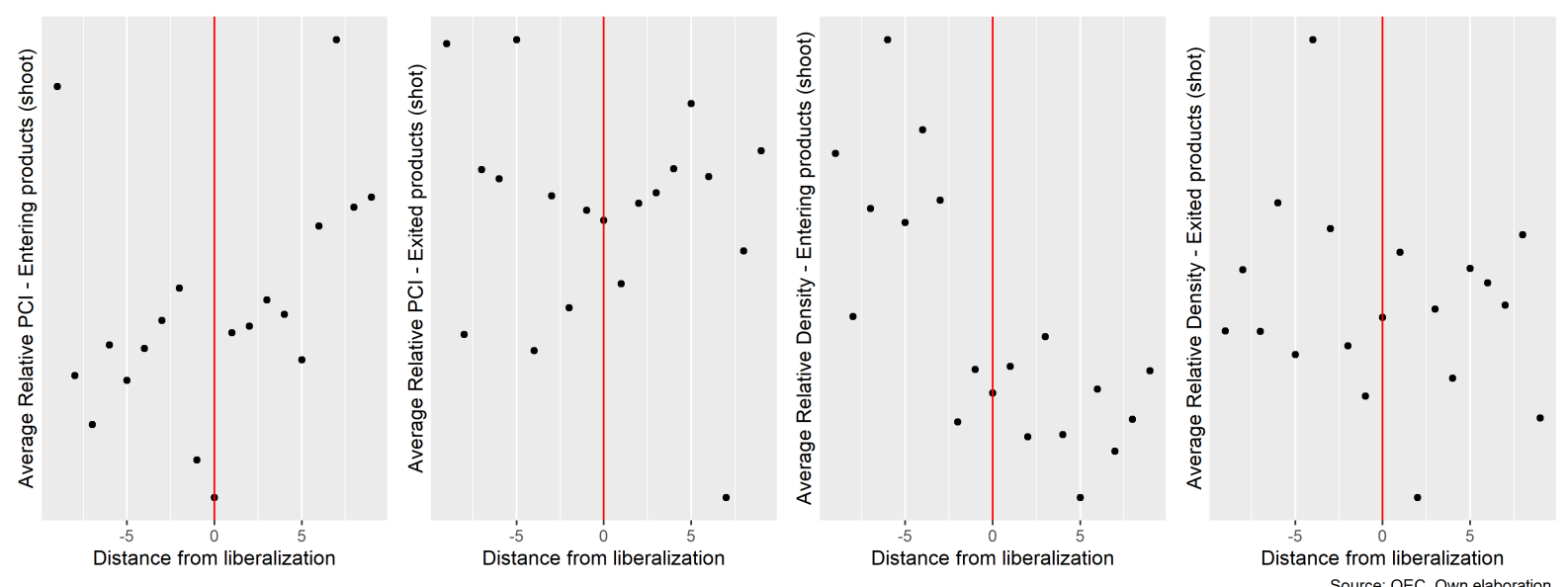

In Figure 7 it is noticeable that both shoots and shots seem to have a relatively stable value for the relative PCI before and after reforms. Although shoots have a slight difference of levels before and after the reforms, it is not a pronounced one. That is also true, but in the other way around in respect to the density measure, for which shoots seem to have a lower value after reforms and shots show a quite stable level during the twenty years under analysis. Those two plots for shoots, if were to be confirmed by regressions analysis, would show a positive impact of opening to the external market both in regard to producing more complex goods (with higher PCI) and acquiring new capabilities unrelated to the ones currently in use (lower density averages). However, both studies again seem to suffer from a composition effect, specially the density analysis is influenced by the low average density of only four countries after the reforms, two in Asia (Sri Lanka and Philippines) and two in the Middle East (Israel and Turkey).

$\overline{27}$ Goldberg et al. (2010) finds results that go in line with this reasoning and is later discussed in the next chapter. 
Regressions in Table 3 below show that no first impression in the event studies is later confirmed by statistical analysis. All estimations here are fixed effect models and consider first the impact of the reforms on the series and then add some control variables. In columns 1 and 4 the definition of new markets take into account a three years period instead of four. For none, however, there seems to be any statistical significant correlation between the reforms and the engagement in the markets of more complex goods. Even though not reported, the results go in the same direction if it is considered a two years window for entering a new market ${ }^{28}$, as done in Pinheiro et al. (2018). Here the measure for human capital does not seem to be relevant for explaining the level of complexity when expanding the extensive margin. Nonetheless, income is positively correlated with higher complexity of new products, what is coherent with the findings in Pinheiro et al. (2018) that indicate more developed countries are prone to continue entering in more complex markets.

Table 3 - Average $P \tilde{C} I$ and $\tilde{\omega}$ for "shoots" and "shots" after liberalization

\begin{tabular}{|c|c|c|c|c|c|c|}
\hline & \multicolumn{6}{|c|}{ Dependent variable: } \\
\hline & $\begin{array}{c}P \tilde{C} I(3 \mathrm{y}) \\
1\end{array}$ & $\begin{array}{c}P \tilde{C} I(4 \mathrm{y}) \\
2\end{array}$ & $\begin{array}{c}P \tilde{C} I(4 \mathrm{y}) \\
3 \\
\end{array}$ & $\begin{array}{c}\tilde{\omega}(3 \mathrm{y}) \\
4\end{array}$ & $\begin{array}{c}\tilde{\omega}(4 \mathrm{y}) \\
5\end{array}$ & $\begin{array}{c}\tilde{\omega}(4 \mathrm{y}) \\
6\end{array}$ \\
\hline Liberalization (WW) & $\begin{array}{c}0.0451 \\
(0.0490)\end{array}$ & $\begin{array}{c}0.0337 \\
(0.0526)\end{array}$ & $\begin{array}{c}0.0919 \\
(0.0575)\end{array}$ & $\begin{array}{c}-0.131^{* * *} \\
(0.0464)\end{array}$ & $\begin{array}{c}-0.0836^{*} \\
(0.0483)\end{array}$ & $\begin{array}{l}-0.0851 \\
(0.0540)\end{array}$ \\
\hline $\log ($ Human Capital $)$ & & & $\begin{array}{l}-0.495 \\
(0.343)\end{array}$ & & & $\begin{array}{c}1.387^{* * *} \\
(0.329)\end{array}$ \\
\hline $\log \left(\mathrm{GDP}_{p c}\right)$ & & & $\begin{array}{l}1.294^{* *} \\
(0.584)\end{array}$ & & & $\begin{array}{c}-1.575^{* * *} \\
(0.561)\end{array}$ \\
\hline $\log \left(\mathrm{GDP}_{p c}\right)^{2}$ & & & $\begin{array}{l}-0.0547^{*} \\
(0.0328)\end{array}$ & & & $\begin{array}{c}0.0837^{* * *} \\
(0.0314)\end{array}$ \\
\hline $\log ($ Capital Stock $)$ & & & $\begin{array}{l}-0.00815 \\
(0.0502)\end{array}$ & & & $\begin{array}{l}-0.102^{* *} \\
(0.0504)\end{array}$ \\
\hline Constant & $\begin{array}{c}-0.322^{* * *} \\
(0.0339)\end{array}$ & $\begin{array}{c}-0.311^{* * *} \\
(0.0367)\end{array}$ & $\begin{array}{c}-7.075^{* * *} \\
(2.520)\end{array}$ & $\begin{array}{c}0.494^{* * *} \\
(0.0319)\end{array}$ & $\begin{array}{c}0.469^{* * *} \\
(0.0337)\end{array}$ & $\begin{array}{c}7.824^{* * *} \\
(2.426)\end{array}$ \\
\hline Observations & 2,506 & 2,381 & 2,342 & 2,580 & 2,456 & 2,409 \\
\hline R-squared & 0.491 & 0.472 & 0.480 & 0.205 & 0.200 & 0.208 \\
\hline $\mathrm{N}^{\mathrm{O}}$ countries & 83 & 83 & 83 & 83 & 83 & 83 \\
\hline
\end{tabular}

Columns 4 to 6 in Table 3 depict the relative density measure of entering products. Pinheiro et al. (2018), similarly to the findings in Cadot, Carrere and Strauss-Kahn (2011), shows that countries usually enter activities closer to their product space - those with

28 Since data from OEC allowed for the construction of density measure for a greater sample than the one for which the Economic Complexity Index is available, regressions performed in Table 3 were also tested for a broader sample of 120 countries. However, including new observations do not alter previous results in any significant way. Again liberalization has impact only when considering the three years window for relative comparative advantage. 
greater density value -, but it is precisely the effort of shooting high that is most associated with higher growth prospects afterwards. Again results are loose and vary greatly for little changes in the definition of new markets or the inclusion of control variables. Although liberalization seems to have a negative correlation with the density of new entering products when considering the three years window, the four years range reduces the coefficient's magnitude and significance. More than that, even though the coefficient changes only slightly after the inclusion of control variables, it loses its significance completely. If it was to be considered the more broader definition for the SW index, which reads it as an institutional pro-market change, those initial results could be related to the ones in Boschma and Capone (2015), that finds a greater ability to jump further in the product space for those countries with more market liberalized arrangements (next section stresses this argument further with a larger sample and another empirical assessment). However, the fragility of the results here limits such conclusions and shows once more that this measure for liberalization cannot be related with changes in the complexity of exports. At last, the magnitudes and significance of the coefficients associated with income are in line with Pinheiro et al. (2018), since they find that intermediate levels of development are those more related with greater leaps in the product space (entrance in less related activities, or lower density). Therefore, as the level of income increases countries are more able to enter in unrelated activities, but this goes up to a certain level and it is later reversed. For this last regression, the coefficient for capital stock is also in line with previous findings in the literature, for which greater endowments seem to be related with the ability of jumping further in the product space.

\subsubsection{Liberalization and unrelated activities}

At last, it was performed an empirical approach similar to the one adopted by Boschma and Capone (2015) to further understand how openness to trade impacted the behavior of the product space. Their findings, as mentioned in the literature review (Section 1.2), show that economies which had a liberalized market institutional framework (regarding both formal and "informal rules") were more able to engage in unrelated activities. The reasoning for such result would be that liberal market economies were more open to radical innovations as they relied more heavily on market solutions, instead of the incremental innovations that would be associated with coordinated economies. Such arrangement would result in the emergence of unrelated industries and a different pattern of diversification. By their methodology, liberal and coordinated institutions were measured through indexes constructed by the Variety of Capitalism (VoC) literature, which considered informal arrangements more extensively than the SW's variable, which is focused exclusively in objective rules. Nonetheless, as was already discussed, the interpretation of the SW's index as also responsible for identifying more liberalized economies has already been suggested by (GIAVAZZI; TABELLINI, 2005) and others. 
Empirical assessment is performed through a linear probability model in which observations are at the industry-country-year level ${ }^{29}$. The endogenous variable $\left(R C A_{p, c, t+5}\right)$ is a dummy that indicates if the country $c$ has comparative advantage in exporting $p$ in the future $(t+5)$. Density $\left(\omega_{c, p, t}\right)$ becomes an explanatory variable, alongside its interaction with liberalization policies $\left(L i b_{c, t}\right)$, which is the main parameter under analysis for Boschma and Capone (2015). A negative coefficient for this interaction would indicate that liberalized economies are able to show relative comparative advantage for lower density values and, therefore, would be able to maintain or acquire comparative advantage in more unrelated activities. Finally, as to disentangle the effect of shoots and already competitive industries, Boschma and Capone interacts the density measure both with $R C A_{p, c, t}$ and $\left(1-R C A_{p, c, t}\right)$. Whereas the first will value 1 when the country does present comparative advantage at period $t$, the latter equals unity in the opposite case.

Taking stock of what was already discussed both in Section 1.3 and by Cadot, Carrere and Strauss-Kahn (2011), it is expected that the density measure presents a positive relation with future comparative advantage both for industries already established and for those that the country is still to engage. As already mentioned, countries are prone to export goods that are closer to their product space - and therefore have a higher density measure. Formally, the empirical regression estimated was:

$$
\begin{aligned}
R C A_{p, c, t+5}= & \beta_{0} R C A_{p, c, t}+\beta^{\text {curr. }} R C A_{p, c, t} \cdot \omega_{c, p, t}^{\text {curr. }}+\beta^{\text {new }}\left(1-R C A_{p, c, t}\right) \cdot \omega_{c, p, t}^{\text {new }}+ \\
& +\theta^{\text {curr. }} \operatorname{Lib}_{c, t} \cdot R C A_{p, c, t} \cdot \omega_{c, p, t}^{\text {curr. }}+\theta^{\text {new }} \operatorname{Lib}_{c, t} \cdot\left(1-R C A_{p, c, t}\right) \cdot \omega_{c, p, t}^{\text {new }}+ \\
& +\gamma^{\text {new }} \log \left(H C_{c, t}\right) \cdot\left(1-R C A_{p, c, t}\right) \cdot \omega_{c, p, t}^{\text {new }}+\delta_{c}+\delta_{p}+\delta_{t}+\epsilon_{c, p, t}
\end{aligned}
$$

where $\log \left(H C_{c, t}\right)$ stands for the logarithm of the human capital index from the Penn World Table (FEENSTRA; INKLAAR; TIMMER, 2015) and is included as a robustness check to be compared with previous exercises. Since it is interacted only with new industries, a negative coefficient would indicate a higher ability to shoot high, or enter in unrelated activities, for those countries with a greater stock of human capital. Finally, there are three set of dummies $\left(\delta_{i}\right)$ for country $(c)$, industry $(p)$ and year $(t)$ effects, respectively. The estimated results are in Table 4 comprising both the restricted sample considered throughout this study and a broader one that includes 12 new countries for which there was available data during at least 40 years.

Firstly, coefficients for the density measure and for human capital follow what would be expected. Density for both newly entered and current activities show positive and significant coefficients, indicating that countries engage and remain competitive in products that are closer to their set of capabilities. As for human capital, higher values are

29 The least square regression is used due to the large number of parameters to be estimated (as to control for year, industry and country average effects) that could jeopardize limited dependent variable models (BOSCHMA; CAPONE, 2015). 
Table 4 - Interacting SW's index with density

\begin{tabular}{|c|c|c|c|c|c|c|}
\hline & \multicolumn{6}{|c|}{ Dependent variable: } \\
\hline & \multicolumn{4}{|c|}{$R C A_{t+5}$} & \multirow{3}{*}{$\begin{array}{c}R C A_{t+5}^{3} \\
2005 \\
5\end{array}$} & \multirow{3}{*}{$\begin{array}{c}R C A_{t+5}^{4} \\
2005 \\
6\end{array}$} \\
\hline & Restrict Sample & 1980 & 1990 & 2005 & & \\
\hline & 1 & 2 & 3 & 4 & & \\
\hline \multirow[t]{2}{*}{$R C A_{t}$} & $0.107^{* * *}$ & $0.0811^{* * *}$ & $0.0962^{* * *}$ & $0.107^{* * *}$ & $0.0324^{* * *}$ & $0.0178^{* * *}$ \\
\hline & $(0.00204)$ & $(0.00330)$ & $(0.00253)$ & $(0.00193)$ & $(0.00121)$ & $(0.000989)$ \\
\hline \multirow{2}{*}{$\omega_{p, c, t}^{\text {current }}$} & $1.598 * * *$ & $1.689^{* * *}$ & $1.589^{* * *}$ & $1.597 * * *$ & $0.827^{* * *}$ & $0.607^{* * *}$ \\
\hline & $(0.0213)$ & $(0.0415)$ & $(0.0280)$ & $(0.0208)$ & $(0.0134)$ & $(0.0112)$ \\
\hline \multirow[t]{2}{*}{$\omega_{p, c, t}^{n e w}$} & $1.899^{* * *}$ & $2.027 * * *$ & $1.970 * * *$ & $1.886^{* * *}$ & $0.732^{* * *}$ & $0.487^{* * *}$ \\
\hline & $(0.0252)$ & $(0.0467)$ & $(0.0333)$ & $(0.0248)$ & $(0.0148)$ & $(0.0121)$ \\
\hline \multirow{2}{*}{$\operatorname{Lib} \cdot \omega_{p, c, t}^{\text {current }}$} & $-0.169^{* * *}$ & $-0.151 * * *$ & $-0.121^{* * *}$ & $-0.145^{* * *}$ & $-0.0725^{* * *}$ & $-0.0547^{* * *}$ \\
\hline & $(0.0153)$ & $(0.0346)$ & $(0.0235)$ & $(0.0151)$ & $(0.0101)$ & $(0.00839)$ \\
\hline \multirow{2}{*}{$\operatorname{Lib} \cdot \omega_{p, c, t}^{n e w}$} & $-0.241 * * *$ & $-0.256^{* * *}$ & $-0.183^{* * *}$ & $-0.233^{* * *}$ & $-0.0832^{* * *}$ & $-0.0484^{* * *}$ \\
\hline & $(0.0116)$ & $(0.0326)$ & $(0.0213)$ & $(0.0115)$ & $(0.00637)$ & $(0.00500)$ \\
\hline \multirow{2}{*}{$\log ($ Human Capital $) \cdot \omega_{p, c, t}^{\text {new }}$} & $-0.477^{* * *}$ & $-0.511^{* * *}$ & $-0.569^{* * *}$ & $-0.454^{* * *}$ & $-0.182^{* * *}$ & $-0.124^{* * *}$ \\
\hline & $(0.0224)$ & $(0.0441)$ & $(0.0309)$ & $(0.0221)$ & $(0.0139)$ & $(0.0115)$ \\
\hline \multirow[t]{2}{*}{ Constant } & $0.0350 * * *$ & $0.0703^{* * *}$ & $0.0548 * * *$ & $0.0392^{* * *}$ & $-0.0227^{* * *}$ & $-0.0192^{* * *}$ \\
\hline & $(0.00204)$ & $(0.00428)$ & $(0.00282)$ & $(0.00196)$ & $(0.00106)$ & $(0.000838)$ \\
\hline Observations & $1,583,785$ & 533,310 & 928,419 & $1,654,204$ & $1,654,202$ & $1,654,201$ \\
\hline R-squared & 0.091 & 0.089 & 0.089 & 0.093 & 0.080 & 0.076 \\
\hline Countries & 83 & 95 & 95 & 95 & 95 & 95 \\
\hline Years & 44 & 19 & 29 & 44 & 44 & 44 \\
\hline \multicolumn{7}{|c|}{$\begin{array}{l}\text { Robust standard errors in parentheses } \\
\quad * * * \mathrm{p}<0.01, * * \mathrm{p}<0.05, * \mathrm{p}<0.1\end{array}$} \\
\hline
\end{tabular}

associated with the engagement in unrelated activities, represented by the negative sign. Liberalization, by its turn, has coefficients in line to the findings in Boschma and Capone (2015): liberalized economies are associated with engaging in unrelated industries and being able to preserve their export advantage at more distant industries.

All those results are robust to changes in the sample size, time window and definition of future comparative advantage $\left(R C A_{t+5}\right)$. In the first column the sample used is the same as all other regressions reported above (Apenddix A.2), while the next three columns include 12 new countries (Appendix A.3) and widens the time span from initially finishing in 1980 up to 2005, the last year considered in this study. Since Wacziarg and Welch (2008) and Billmeier and Nannicini (2013) suggested the benefits from opening would be different according to when the country went through the reforms, this regression indicates that there is no changing in the pattern of this specific coefficient. In other words, liberalization reforms seem to be related with a greater capacity of entering and remaining competitive in unrelated industries for all time periods considered. Finally, the last two columns alter the measure of having comparative advantage in the future by considering those goods for which the country was a relevant exporter for at least three $\left(R C A_{t+5}^{3}\right.$ - Column 5$)$ and four consecutive years $\left(R C A_{t+5}^{4}\right.$ - Column 6$)$. It can be noticed that all coefficients show lower values for these two columns, since the new definition restricts which products are considered, still all results point in the same direction as before. 
At last, Table 5 tries to identify a possible heterogeneous effect of liberalization policies on developing countries, as results in Table 2 had suggested, by using the index presented in $\mathrm{Ju}, \mathrm{Wu}$ and Zeng (2010). Once again there is some evidence of a different impact considering income levels, WZJ's index is used in the first two columns and is noticeable that all coefficients show the same sign than before, except the ones associated with liberal measures. Now liberalization is no longer associated with remaining or engaging in more unrelated activities as it was. Whereas the interaction with activities for which the country currently has comparative advantage shows statistical significance for both measures of future exports $\left(R C A_{t+5}\right.$ and $\left.R C A_{t+5}^{4}\right)$, the one associated with entering industries is significant only for products that last at least four years in the export basket with RCA. Nonetheless, all four coefficients have opposite signs.

Table 5 - Income heterogeneity

\begin{tabular}{|c|c|c|c|c|c|c|}
\hline & \multicolumn{6}{|c|}{ Index: } \\
\hline & \multicolumn{2}{|c|}{ WJZ } & \multicolumn{4}{|c|}{ WW } \\
\hline & $\begin{array}{c}2005 \\
1 \\
\end{array}$ & $\begin{array}{l}R C A_{t+5}^{4} \\
2\end{array}$ & $\begin{array}{c}\text { Latin America } \\
3\end{array}$ & $\begin{array}{c}\text { Africa } \\
4\end{array}$ & $\begin{array}{c}\text { Asia } \\
5\end{array}$ & $\begin{array}{c}\text { Europe } \\
6 \\
\end{array}$ \\
\hline $\mathrm{RCA}_{-} \mathrm{t}$ & $\begin{array}{r}0.0599 * * * \\
(0.00310)\end{array}$ & $\begin{array}{c}0.00412^{* * *} \\
(0.00153)\end{array}$ & $\begin{array}{l}0.0642^{* * *} \\
(0.00447)\end{array}$ & $\begin{array}{c}0.0501^{* * *} \\
(0.00432)\end{array}$ & $\begin{array}{c}0.0852^{* * *} \\
(0.00533)\end{array}$ & $\begin{array}{r}0.0666^{* * *} \\
(0.00510)\end{array}$ \\
\hline$\omega_{p, c, t}^{\text {current }}$ & $\begin{array}{l}1.602^{* * *} \\
(0.0312)\end{array}$ & $\begin{array}{c}0.566^{* * *} \\
(0.0159)\end{array}$ & $\begin{array}{l}1.762^{* * *} \\
(0.0512)\end{array}$ & $\begin{array}{l}1.827^{* * *} \\
(0.0749)\end{array}$ & $\begin{array}{l}1.751^{* * *} \\
(0.0388)\end{array}$ & $\begin{array}{l}1.612^{* * *} \\
(0.0424)\end{array}$ \\
\hline$\omega_{p, c, t}^{n e w}$ & $\begin{array}{l}1.707^{* * *} \\
(0.0421)\end{array}$ & $\begin{array}{c}0.486 * * * \\
(0.0208)\end{array}$ & $\begin{array}{c}2.045^{* * *} \\
(0.0683)\end{array}$ & $\begin{array}{c}1.717^{* * *} \\
(0.0855)\end{array}$ & $\begin{array}{l}2.133^{* * *} \\
(0.0490)\end{array}$ & $\begin{array}{l}2.334^{* * *} \\
(0.0565)\end{array}$ \\
\hline $\operatorname{Lib}(\mathrm{WJZ}) \cdot \omega_{p, c, t}^{\text {current }}$ & $\begin{array}{l}0.0575^{* *} \\
(0.0225)\end{array}$ & $\begin{array}{l}0.112^{* * *} \\
(0.0136)\end{array}$ & & & & \\
\hline $\operatorname{Lib}(\mathrm{WJZ}) \cdot \omega_{p, c, t}^{n e w}$ & $\begin{array}{l}0.00123 \\
(0.0169)\end{array}$ & $\begin{array}{l}0.0190 * * * \\
(0.00705)\end{array}$ & & & & \\
\hline $\operatorname{Lib}(\mathrm{WW}) \cdot \omega_{p, c, t}^{\text {current }}$ & & & $\begin{array}{c}0.156^{* * *} \\
(0.0369)\end{array}$ & $\begin{array}{c}0.0649 \\
(0.0559)\end{array}$ & $\begin{array}{c}-0.131^{* * * *} \\
(0.0336)\end{array}$ & $\begin{array}{c}-0.216^{* * *} \\
(0.0274)\end{array}$ \\
\hline $\operatorname{Lib}(\mathrm{WW}) \cdot \omega_{p, c, t}^{n e w}$ & & & $\begin{array}{l}0.0493^{*} \\
(0.0282)\end{array}$ & $\begin{array}{c}-0.274^{* * *} \\
(0.0379)\end{array}$ & $\begin{array}{c}-0.115^{* * *} \\
(0.0285)\end{array}$ & $\begin{array}{c}-0.380 * * * \\
(0.0218)\end{array}$ \\
\hline $\log ($ Human Capital $) \cdot \omega_{p, c, t}^{n e w}$ & $\begin{array}{c}-0.605^{* * *} \\
(0.0533)\end{array}$ & $\begin{array}{c}-0.312^{* * * *} \\
(0.0269)\end{array}$ & $\begin{array}{c}-0.594^{* * *} \\
(0.0887)\end{array}$ & $\begin{array}{l}-0.165 \\
(0.122)\end{array}$ & $\begin{array}{c}-0.875^{* * *} \\
(0.0546)\end{array}$ & $\begin{array}{c}-0.809 * * * \\
(0.0398)\end{array}$ \\
\hline Constant & $\begin{array}{c}0.0700 * * * \\
(0.00228)\end{array}$ & $\begin{array}{c}-0.00394^{* * *} \\
(0.000984)\end{array}$ & $\begin{array}{c}0.0541^{* * *} \\
(0.00315)\end{array}$ & $\begin{array}{l}0.118^{* * *} \\
(0.00289)\end{array}$ & $\begin{array}{c}0.0210^{* * *} \\
(0.00351)\end{array}$ & $\begin{array}{r}0.0315^{* * *} \\
(0.00564)\end{array}$ \\
\hline Observations & 565,118 & 565,115 & 323,327 & 251,571 & 297,457 & 558,958 \\
\hline R-squared & 0.146 & 0.128 & 0.138 & 0.182 & 0.179 & 0.107 \\
\hline Countries & 36 & 36 & 21 & 30 & 13 & 21 \\
\hline Years & 44 & 44 & 44 & 44 & 44 & 44 \\
\hline
\end{tabular}

Columns 3 to 6 use the WW's index once again, but considers each region separately and reveals the difference between Latin America and Africa from Europe and Asia. Only for the latter two coefficients are in line with what was found for the whole sample, it is their behavior, therefore, that dictates the finding of a greater capacity of entering in unrelated activities after liberalization reforms. As can be noticed in Columns 3 and 4, 
this pattern is not homogeneous across different income levels since for both continents the interaction of the WW's variable with the density of currently exported goods show a positive sign, similarly to the result of the WZJ's variable. The interaction with shoots, however, seems to be different only for Latin America, that shows a positive coefficient which is almost the same absolute magnitude of the Asian one, indicating opposite impacts for both regions. Since the index captures an once and for all change of objective rules towards liberalization, it could be that after the reforms each region differed on how far it went in the liberal path and that is what these coefficients are actually indicating. Nonetheless, what Table 5 suggests is a significant heterogeneous impact after the adoption of similar liberalization measures. Restricting the time period as done in Table 4 is very little informative for both Africa and Latin America, since most of the reforms occurred in the late 1980s and early 1990s. As for Europe, coefficients are not significant when considering only up to 1980s, but including the 1990s is already sufficient to have the same results as for the whole sample. At last, Asia is the region with most consistent results for different time windows. The only remarkable change is the non significance of the interaction between liberalization and entering industries when looking up to the 1990s, but all coefficients behave as expected when considering the 1980s.

Certainly the measure used here for classifying institutions is much more limited than the one considered by Boschma and Capone (2015), nonetheless results point to a very similar direction. What is most interesting, however, is the fact that once again it was possible to identify a heterogeneous impact of those measures depending on the stage of development. If the Varieties of Capitalism literature is focused on developed economies, the Sachs and Warner's variable allowed for expanding this horizon with puzzling results. Boschma and Capone suggests that more liberal market institutions would open a greater space for disruptive innovation, resulting in the capacity to engage in unrelated industries. Considering the SW's variable as identifying extensions in the "scope of the market", it could be argued that not necessarily greater competition will spur innovation in developing nations and could, on the contrary, limit their ability to move across the product space.

\subsection{Discussion}

This study has tried to interact three kinds of policy recommendations debated in the literature: favoring pro-market institutions and openness to trade, enhancing export diversification and improving economic complexity. The last two of them are closely connected, even though not completely interchangeable, as depicted in Figure 2 above. Considering how ubiquitous are the exported goods along with the diversification measures seems to capture more robustly the relation between the productive structure and income, as was the case for Ireland. If diversifying exports was to be considered a policy objective (CADOT; CARRERE; STRAUSS-KAHN, 2011), this brings some new food for thought. 
If now there is more space to question the idea that conforming sound market institutions could be enough for convergence (CHERIF; HASANOV, 2019), this study helps to reinforce this perspective, at least by the absence of evidence. Firat (2020), for instance, also found that the IMF's structural adjustment programs have had no impact over the composition of exports for the borrowing countries and, therefore, was unable to strengthen this channel of fostering growth.

So far the literature on economic complexity has focused in finding how enhanced complexity comes along greater social cohesion and growth prospects (GALA; ROCHA; MAGACHO, 2018; HAUSMANN; HIDALGO, 2014), while the diversification agenda has understood concentration as the resulting process of the interaction between investment opportunities and transport costs. As presented by Imbs and Wacziarg (2003) the Engle Law predicts that diversification will be fostered as income increases, but it will only be so if this new demand can not be fulfilled by external markets as transport costs fall. If closing the technological gap necessary for entering new markets takes longer than reducing those costs - considered to be negatively correlated with capital accumulation -, then concentration will prevail after a given point. Cadot, Carrere and Strauss-Kahn (2011) have a similar explanation since they see a mapping between the entrance in new activities and the accumulated levels of capabilities. Therefore, in their view, diversification actually reflects the different pace between the start in new activities and the process of exiting those that fall behind current levels of production factors.

In both views, however, greater openness to trade would result in lower levels of diversification, if it was to be seen as lower "import costs". Despite such conclusion is followed by Agosin, Alvarez and Bravo-Ortega (2012), the results reported in Table 1 do not confirm such tendency. Even further, Economic Complexity does not seem to follow the same path and shows little correlation with liberalization reforms in any analysis whatsoever. This lower cost channel could be only related to the results shown in Table 2 , indicating that both diversification and complexity were jeopardized by liberalization reforms for poorer countries. Notwithstanding, those estimates were not confirmed by more robust dynamic analysis. Finally, the findings in Boschma and Capone (2015) that point to a greater capacity to engage and remain competitive in unrelated activities for liberalized economies was not confirmed for all levels of income. Among the few conclusions this study could suggest, the heterogeneous impact of liberalization reforms seems to be the most relevant one.

Literature about complexity has seen it as the result of a broad set of capabilities, specially human capital responsible for innovation. Estimations presented by this study show this feature has little to do with degrees of openness to foreign trade and must be persued by policies that aim at it directly ${ }^{30}$. Relating concerns about complexity and 
diversification of exports seems to be a promising path by allying conclusions in these two research strands, something that has been scarcely done. Both empirical and theoretical research have still an open road to unveil the impact of different policies on the productive structure as to build an inclusive growth program. 


\section{Connecting tariff policies to the product}

\section{space}

\subsection{Introduction}

The product space have been increasingly considered as a relevant tool for designing industrial policy ${ }^{1}$. Its usage has been mainly focused on identifying industries closer to the current set of capabilities of a given country. Still, that has been little effort to relate it with other policy instruments. This study tries to contribute for such gap by connecting the trade series constructed by the Observatory of Economic Complexity with the Trade Analysis Information System (TRAINS) from the United Nations, providing tools for the investigation of national tariff policies at the industry level. An empirical application is conduced using the Brazilian liberalization process in the late 1980s and early 1990s. Such episode was marked by the elimination of non-tariff barriers and a drastic tariff reduction in a short period of time (KUME; PIANI; SOUZA, 2003). Analysing the evolution of the product space after a granular intervention like tariff cuts seems useful for better assessing how products interact and how policies are able to influence capabilities.

Different understandings about the role of international trade in development strategies have marked significant shifts for policy design in Brazil. While inwardness marked the industrialization by import substitution period starting in the 1930s for almost fifty years, an outward oriented approach prevailed during the late 1980s until the first decade of the XXI century. Those shifts were due, in a significant matter, to different perspectives on the prominence for the development process of either sound market institutions, or the directing of national productive structure towards industrialized sectors (KUPFER, 1998).

Several studies focused on understanding the impact of liberalization reforms on firms' productivity have found an important role for the access of higher quality and cheaper inputs. Theoretical models of endogenous growth by the Schumpterian theory have indeed emphasized the role of trade for enhancing growth in laggard countries as it enables access to the technological frontier, raising productivity (AGHION; HOWITT, 2006). Empirical evidence with plant-level data has confirmed some of those predictions. Goldberg et al. (2010), for instance, studied the Indian tariff reduction in 1991 after a balance of payment crisis that interrupted a long period of inward oriented production. In this case the impact was not only on productivity, but also resulted in the production of a greater variety of goods. Their findings indicate that new inputs which were were not available

1 See Hartmann, Bezerra and Pinheiro (2019), Romero and Silveira (2019) and Fortunato, Razo and Vrolijk (2015). 
on domestic markets made firms engage in the production of different kinds of goods. Bas and Paunov (2018) found similar results regarding the Ecuador's entrance in the World Trade Organization, which also implied a widespread tariff cut. Access to foreign inputs resulted not only in firms enlarging their product set, but also in a smaller proportion of single-product firms, greater productivity and hiring of better qualified workers.

As for the Brazilian episode in the 1990s most studies do not go after the impact on the variety of goods produced by each firm, instead they are mostly focused on productivity changes related with lower tariffs. Still, both Schor (2004) and Lisboa, Menezes and Schor (2010) point to the relevant role of inputs for enhancing productivity. The former finds heterogeneous effect of greater competition on the output market after tariffs were lowered: only firms on the higher end of the productivity curve were able to become more competitive. On the other hand, the positive impact of lower tariffs on inputs for raising productivity was found to be valid for the whole sample of firms. Lisboa, Menezes and Schor (2010) finds an even stronger result for the relevance of inputs in productivity gains. Their estimations indicate that after controlling for the input effect, greater competition provoked by lower output tariffs become irrelevant for understanding productivity growth. Such result is even larger for companies in capital intensive sectors, suggesting it is mainly related with the adoption of new technologies. It is worth noticing, however, that Muendler (2004) finds somewhat different results for the impact of cheaper inputs, suggesting that this effect would take a while to be in place since firms would have not only to redefine their production processes, but also retrain employees. The main mechanism for greater productivity after liberalization, therefore, would be managerial changes (called as competitive push).

This last channel for enhancing productivity is also stressed by studies that look at a more detailed level for the 1990s, instead of considering empirical exercises for the whole period. Such approach is also very informative since this decade marked two major changes in the competitive environment, firstly the tariff reduction that lasted at least from 1990 through 1994, and secondly, the currency stabilization plan in June of $1994^{2}$. Castro (2001), for instance, argues that Brazil went through a "halted opening" until the new currency was launched, since high inflation and a depreciated exchange rate reduced the incentive to import and, therefore, protected national companies. However, even though the increased competition had not been fully in place, it already had sensible impacts on productivity since new processes and methods were adopted (for instance, managerial practices such as the Total Quality Management and the Just In Time) (CASTRO, 2001).

Mostly, the productivity gains in the beginning of the decade were due to lowering costs and reducing personnel. Iootty, Kupfer and Ferraz (2004) points that Brazil went through

2 Kupfer (1998) describes the rapidly changing economic scenario: "Entre 1980 e 1994 o Brasil experimentou 9 planos de estabilização, 15 políticas de indexação salarial, 19 mudanças nas regras de correção cambial, 22 propostas de equacionamento da dívida externa e 20 planos de ajuste fiscal do estado" (KUPFER, 1998, p. 57). 
minor changes in its sectoral composition after the liberalization reform mostly due to the aggressive cost reduction in several industries. In fact, both the value added and the expenses with employees by manufacturing firms were reduced, but since the latter went through greater cut, the overall productivity grew in the aftermath (KUPFER, 1998). Also Bielschowsky et al. (2000) shows that jointly considering manufacturing, mineral and petroleum industries and infrastructure it can be noticed that their share in total investment was reduced in almost 50\% when the five year period of 1990-94 is compared to the previous decade. Only after the stabilization plan that investments would again be undertaken in what Bielschowsky called a "mini modernization cycle", during which firms aimed at renewing their machinery and reducing costs. Carvalho (2010) indicates further evidence of the cost reduction trend when focusing on the period from 1990 to 1996, which includes two years after the currency reform, and show that all the manufacturing sector reduced its labor share.

Therefore, it seems to be quite unquestionable that the Brazilian industry went through two different periods considering the liberalization reform and the stabilization plan. However, there is an interesting element in regard to the export pattern that it is not much noticed: the positive behavior of manufactured exports in the four years of lower tariffs and high inflation after 1990. Kupfer (1998), for instance, points to the little change of the manufacturing share in exports between 1990 and 1996, since it rose only two percentage points after departing from 54.2\%, however, in 1993 the series has its peak at 60\%. Also, while primary goods and services had a neutral or negative net impact on the balance trade, industrialized products were responsible for a positive result during the first four years of the decade. Such tendency will be latter noticed also on the variety of goods that the country exported with revealed comparative advantage during this first years of liberalization. Even though it was a short period trend, since it comprises all years in which the only relevant macro policy change was the tariff cut, it is interesting to look it further.

Finally, the findings highlighted above were all focused on understanding the impact of tariffs at the plant level, differently from the industry level analysis undertaken by the product space approach. Since this data has no information about how products relate as inputs and outputs, there is also little space to analyze how firms altered their input set, given the new price level, and what they were able to produce after this change. Thus, it will be focused on how sectors (and their related capabilities) reacted to a more significant exposition to foreign competition.

\subsection{The liberalization process}

The last years of the 1980s and the first half of the following decade were decisive moments for the Brazilian policy change towards a more free-market perspective, follow- 
ing the Washington Consensus that prevailed in the public debate. As Gustavo Franco, the Brazilian Central Banker in the late 1990s, posed: "o que se passa com o Brasil nos anos 90 é uma profunda reorientação do 'modelo econômico' segundo a qual algumas reformas importantes (...) mudaram fundamentalmente as condutas dos agentes econômicos ao criarem um imperativo de se buscar a competitividade num contexto macroeconômico relativamente hostil" (FRANCO, 1999, p. 51).

Opening required several measures to dismantle the protective system that had been built during previous decades. Its first step, taken in 1988 and 1989, was to reduce the so called redundant tariffs - those that went beyond the real wedge between national and foreign prices - something that, nonetheless, had little effective impact for imports (LISBOA; MENEZES; SCHOR, 2010). The next set of measures, implemented by the Collor administration, aimed at restricting the protection instruments to the tariff system ending with most of the non-tariff barriers and special import regimes for industrial products. Finally, it was announced a tariff cut schedule that would last from 1991 to 1993 responsible for gradually lowering protection of national companies from international competition (KUME; PIANI; SOUZA, 2003). Kupfer (1998) indicates that the average tariff was at $35 \%$ in 1990, lowered to $16.5 \%$ in the end of 1992 and reached $11.2 \%$ in 1994, a significant change in a short period of time as can be noticed in Figure 8. In the following years this process was slightly reversed, since the commercial balance had deficits already in 1995 and the country went through a severe currency crisis in 1998 that demanded policy responses both on monetary and commercial fronts by depreciating the new currency and raising tariffs once again.

As already mentioned, the coincidence of monetary and trade reforms jeopardize an analysis that focus on tariff cuts, specially because the Real was highly appreciated in its first years ${ }^{3}$ - something that had the practical impact of a price reducing measure in regard to imports. Still, cuts were not focused on any particular sector, instead, they reached all 97 groups of products - considering the level 2 of the Harmonized System (HS) classification, which were here divided into 15 categories $^{4}$ - as shown in Figure 8.

Considering such observations, the next section presents how the Brazilian product space measures behaved during the 1990s, before connecting them to the tariff cuts.

3 Franco celebrates the concurrency of Brazilian reforms as a relevant aspect for tackling inflation: " $A$ simultaneidade entre essa agressiva liberalização das importações, a privatização, a estabilização e a política de bandas cambiais é, sem dúvida, o aspecto mais singular e mais importante da experiência brasileira recente" (FRANCO, 1999, p. 154).

4 The correspondence was based on the classification made by Foreign Trade online, which is referenced by the UN Trade Statistics and is available at $<$ https://www.foreign-trade.com/reference/hscode. htm $>$. 
Figure 8 - Tariffs $(\tau)$ in the 1990s
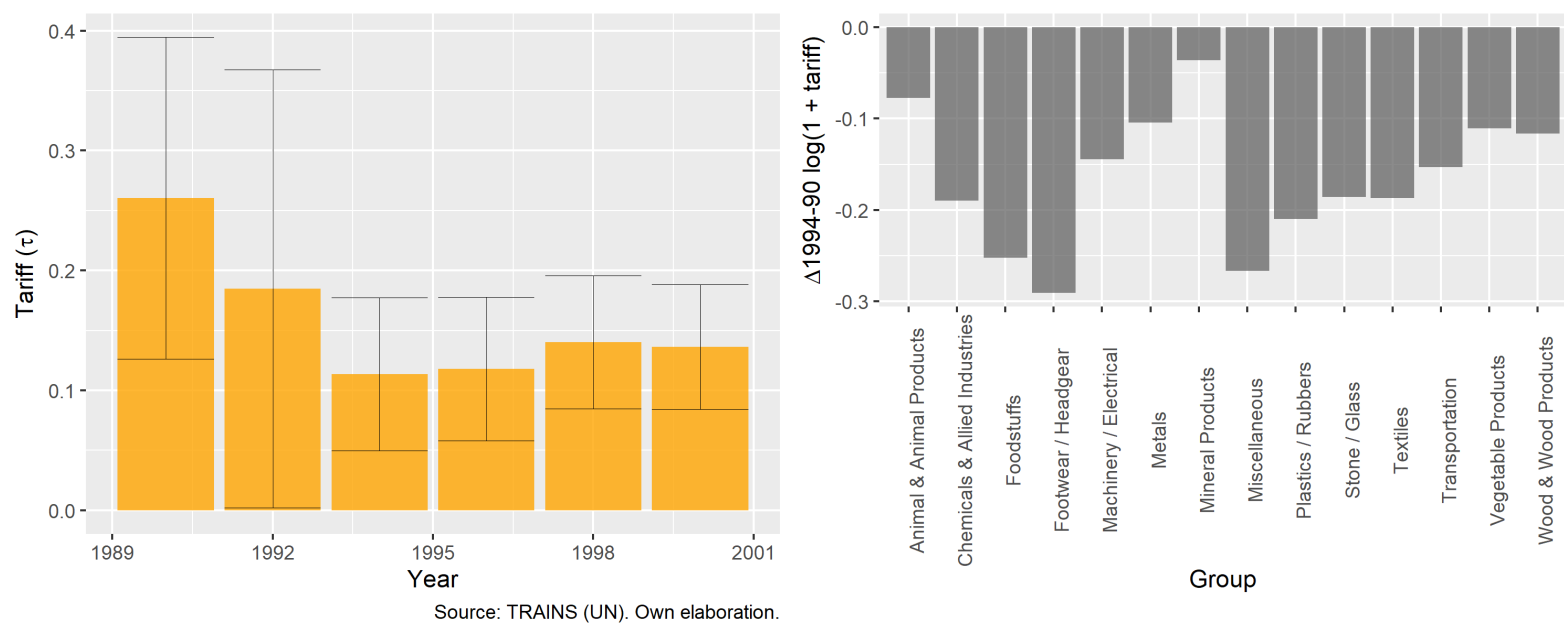

\subsection{Brazilian product space in the 1990s}

The widespread tariff reduction aimed at abruptly letting flourish comparative advantages in the international context. It is interesting to notice, however, that the Brazilian Economic Complexity Index reached its apex precisely in the late 1980s and only decreased since then. Notwithstanding the index dip, its productive structure remained considerably more complex than its Latin American neighbors as can be seen in Figure 9, due mainly to the complexity enhancing process that resulted from the inward oriented period. Analysing the average density of Brazilian exports, understood as a measure of the capabilities needed to produce all goods (density is explained in greater depth in Section 1.3), it can be seen that the country was still engaging in new industries after the liberalization measures and before its monetary reform. It is noticeable, however, that density is much more volatile and related to the diversity of exports than the complexity index. From 1989 to 1993 Brazil started exporting 30 new products with comparative advantage (see Section 1.3), a $17 \%$ growth that resulted in the second most diversified export basket for the whole sample. This connection with diversity is also clear in 1994 when the number of goods exported with comparative advantage begins its reduction that lasts up to 1998, when the country reaches back the level from 1990. Even though density was recovered by the end of the decade, when exports were benefited by the currency devaluation, it was reduced again afterwards similarly to the complexity measure.

This continued upwards tendency of the average density up to 1994 occurred during the "surgery and reorganization" period, as named by Castro (2001), in which most manufacturing industries were focused on enhancing productivity by cost reduction, instead of new investments in capital and equipment due to the recession and the inflationary scenario. The fact that new industries found space to compete in the international market during this period, and after facing greater competition in the internal market, is a interesting remark to be added for the understanding of those reforms. It is worth noticing 
that both the diversity of exports and the average density presented a "N" pattern when considering the 1990s, latter followed by a monotone decrease. After the initial increase already mentioned, both measures were reduced in the aftermath of the currency reform, simultaneously with a worsening of the Balance of Payments. Carvalho (2010) shows that from 1990 up to 1996 trade represented a six percentage point reduction in the value added by the manufacturing sector. Later, the conjunction of raising tariffs, depreciating the Real and abandoning its pegged value to the US dollar, and probably as the result of the investments undertaken during the "mini modernization cycle" (BIELSCHOWSKY et al., 2000), Brazilian exports regained positions in the international market. However, this last movement of the 1990s was also fragile, being completely reversed in the 2000s as the commodities boom began.

Figure 9 - Measures for the Brazilian productive structure
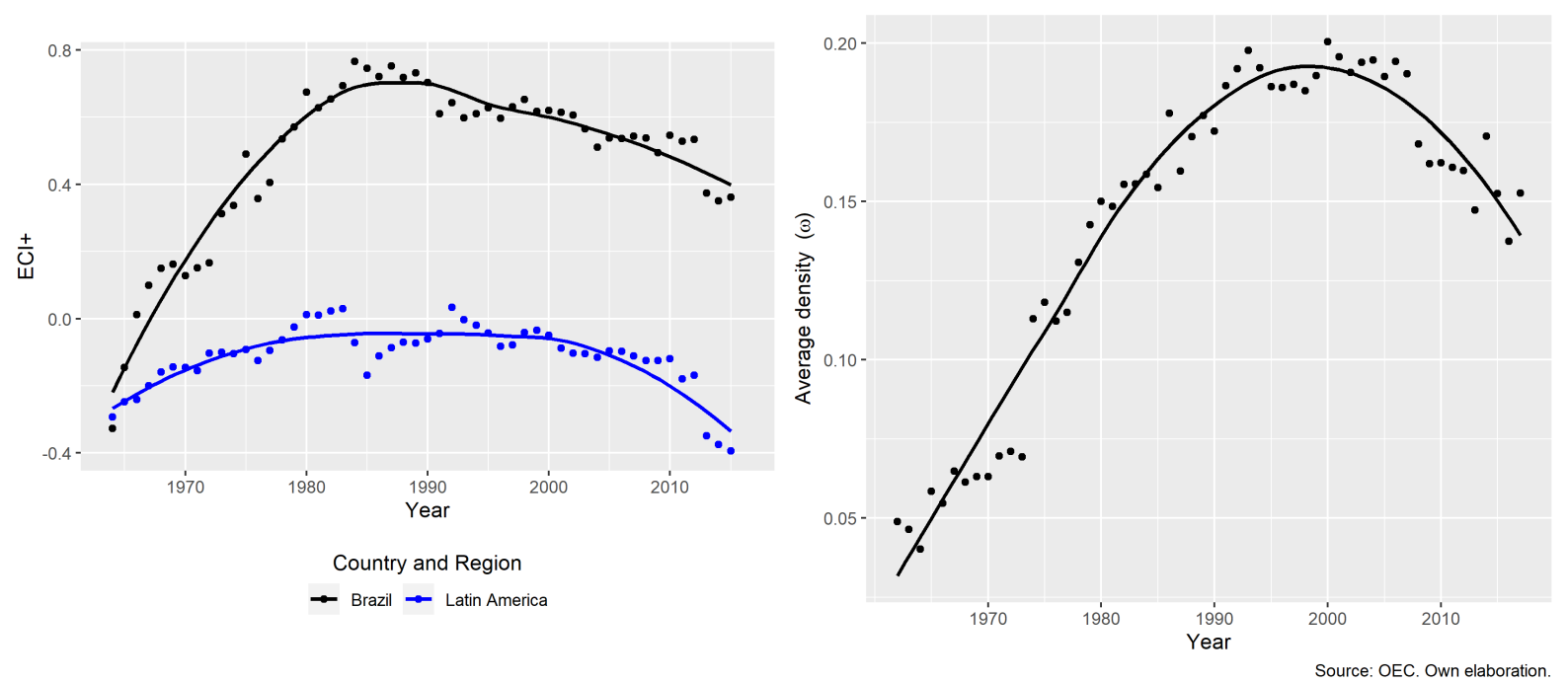

This continued deterioration of the Brazilian productive structure, as measured by the complexity index, and the stable value at a low level for the whole continent is indicated by Hartmann et al. (2017b) to be one crucial aspect that limits the region's structural condition to overcome its historical high level of income inequality. Even though recent policies were devoted to reduce such income differential, little has changed the continent's role in the international trade. Differently from what has happened in some East Asian countries (especially China, South Korea, Singapore and Taiwan), where policies were able to take structural transformations underway (HARTMANN et al., 2017b). Linking the characteristics of goods exported by each country to income inequality is another relevant aspect of the economic complexity agenda that will be latter explored as to understand into which direction its export basket evolved after the tariff cut reform.

Notwithstanding, the already mentioned decay of overall complexity is not evident when considering the relative Product Complexity Index distribution of the goods exported by Brazil with comparative advantage. Figure 10 shows the histogram for three different years (1980, 1990 and 2000) and points to a small difference between them, con- 
firming at least partially what Iootty, Kupfer and Ferraz (2004) suggests for the little change in the Brazilian manufacturing sector's landscape after the reforms. Such unaltered configuration is reinforced by a methodology bias focused on exports. Since capital intensive and high-end technology were already unable to export and compete in the international market, the fact that they were most affected by foreign competition becomes less pronounced in export data. Still, it is possible to notice that the 2000's distribution presents a small reversion of goods with greater relative complexity (see Section 1.3) when compared to the 1990's distribution. On the other hand, it is also the very most diversified year of the sample presenting 204 goods exported with comparative advantage $\left(k_{c, 0}\right)$, against 176 in 1990 and 171 in 1980. By its turn, the 1980's distribution dominates the other two in the less relatively complex goods region (those with PCI smaller than zero). Therefore, at first sight the liberalization period has not provoked an unidirectional change in the product space behavior.

Figure 10 - Brazilian $\tilde{P C I}(\mathrm{RCA})$ by decade

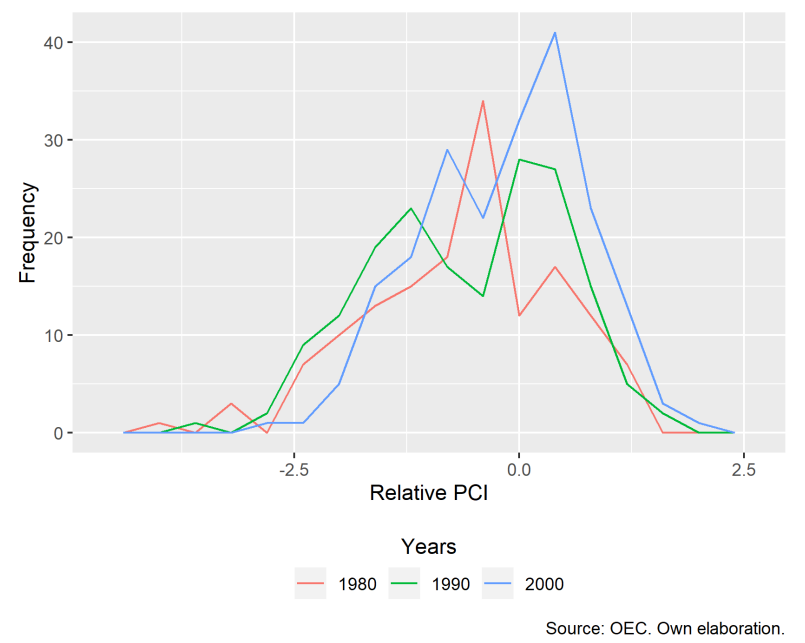

After this initial analysis of the product space measures for Brazil, next section presents the data used in the empirical exercise conducted to relate the tariff cuts to the behavior of such measures.

\subsection{Data}

The Observatory of Economic Complexity (OEC) provides data for imports and exports classified by product using the Standard International Trade Classification (SITC) Revision 2 from 1974. Brazilian data ranges from 1964 to 2017 and identifies 943 goods by four digit codes. Tariff data from TRAINS (UN) is classified by the Harmonized System (HS) 6-digit and has 7631 different products, considering all revisions for the HS and 
comprising data from 1990 to 2014 for every two years. Making these datasets compatible, therefore, required matching the SITC and HS codes ${ }^{5}$.

The other measures used to analyse the behavior of the Brazilian product space were the PRODY (HAUSMANN; HWANG; RODRIK, 2007) and the Product Gini Index (PGI) (HARTMANN et al., 2017a). Both were constructed as in Hartmann et al. (2017a) using the weighted average of the GDP per capita and the Gini index, respectively, as follows:

$$
Y_{p}=\frac{1}{N_{p}} \sum_{c} s_{c, p} \mathbb{I}\left[R C A_{c, p}>1\right] X_{c}
$$

where $Y_{p}$ stands for the PGI (PRODY), $s_{c, p}$ is the share of product $p$ on the export basket of country $c, \mathbb{I}\left[R C A_{c, p}>1\right]$ is the indicator function that equals unity if country $c$ has comparative advantage on the export of product $p, N_{p}=\sum_{p} \mathbb{I}\left[R C A_{c, p}>1\right] s_{c, p}$ is a normalizing factor and, finally, $X_{c}$ stands for the GINI (GDP per capita) measure. Since trade data tend to present a much volatile behavior, it was used a three year average for both variables. Data for GDP per capita was taken from the Penn World Table (FEENSTRA; INKLAAR; TIMMER, 2015) and the Gini Index from the GINI EHII dataset (GALBRAITH et al., 2015). Since the Gini index was not estimated for all years and countries in the sample, the missing observations were filled with the average Gini of the income level that the country belonged in the World Bank's classification for that year.

Both indexes help to quantify the relation between countries' social features and their export basket, as mentioned in Section 1.3. By using only those countries that export with relative comparative advantage they also focus on attaching to each product the characteristics of nations that are more closely connected to those industries. As indicated by both Hausmann, Hwang and Rodrik (2007) and Hidalgo et al. (2007) these measures are good predictors of future growth prospects and lower inequality, respectively. Even though it has an endogenous construction, as posed by the authors "rich countries are those that have latched on to 'rich-country products"' (HAUSMANN; HWANG; RODRIK, 2007, p. 2), those measures help to differentiate goods and understand how to classify the capabilities that are being developed by each country through their exported products.

\subsection{Impact of tariff reduction}

Identifying a causal impact of trade liberalization in the product space is hard to be assessed considering the multi variable dimension of its composition. Not only because the

5 Correspondence tables between codes are available in the UN Trade Statistics website and help identify some of the codes, others must be matched by commodity description comparison. The final correspondence table connects 6438 HS codes to 801 SITC codes used by the OEC. Since the Observatory has made available data in the Harmonized System only beginning in 1995, the matching was required as to use the first two periods in the TRAINS dataset. Appendix B.1 presents the code used for this matching. 
concept of capabilities invokes several aspects that are way beyond the economic sphere, but also because other economic features also matters in a considerable manner, such as the exchange rate already discussed.

Empirical identification will be proceeded using a fixed effects regression as to measure correlations between products relative densities - in relation to the Brazilian product space - and tariff changes for both the product itself and its closest neighbors using four different time windows all beginning in 1990 (ranging to 1994, 96, 98 and 2000). This specification is similar to the one undertaken by Alessandrini et al. (2011), in which they identify that market concentration - measured by the Lafay's revealed comparative advantage index was greater in industries that were more exposed to foreign competition. By using the density measure, therefore, this exercise tries to identify a relation between reducing protection and the behavior of the product space in regard to that specific industry. At last, since distant periods from 1994 tend to amplify the impacts of other economic reforms than tariff cuts, time dummies were included for all years as to incorporate economic aspects that affected all industries simultaneously. Hence, the specification bellow indicates how Brazilian product space reacted to different degrees of protection reduction:

$$
\tilde{\omega}_{p, t}=\beta_{\phi} \tau_{\phi, t}+\beta_{p} \tau_{p, t}+d_{t}+\delta_{s=S} \mathbb{I}[p \in S] \cdot \tau_{p, r}+\alpha_{p}+\gamma_{t}+z_{p, t}
$$

where $\tilde{\omega}_{p, t}$ stands for the relative density of product $p ; \tau_{p, t}$ represents tariff on product $p$, while $\tau_{\phi, t}$ represents the average tariffs of proximate products by a given $\phi_{p, p^{\prime}}$ criteria; finally, $\mathbb{I}[p \in S]$ is the indicator function for all the 10 groups of products in the SITC Rev. $2(S)^{6}$. The other terms in 2.1 stand for time dummies $\left(\gamma_{t}\right)$, an industry specific effect $\left(\alpha_{p}\right)$ - accounting for different patterns of competition (IOOTTY; KUPFER; FERRAZ, 2004) - and $z_{p, t}$ is the industry-year shock.

Results reported in Table 6 for each time window consider as close products those that had $\phi_{p, p^{\prime}}$ in the $95^{\text {th }}$ percentile of the proximity distribution or greater (see Section 1.3). Since tariffs were drastically reduced during the whole period, negative coefficients indicate tariff reduction is related with increases in relative density. It is interesting to notice that own tariff changes do not show statistical significance for any period, while tariff changes for close products presents significance for the first round of changes (before 1996) with a negative sign. Therefore, the impact of one negative standard deviation in tariffs for the nearest products in 1994 was related to a density change of $(-0.063) \cdot(-1.030)=0.065$, what is of small relevance considering that relative density's standard deviation measured 0.59 in that year.

$6 \quad$ The groups defined by the UN Comtrade are: 1 - Food and live animals chiefly for food; 2 - Beverages and tobacco; 3 - Crude materials, inedible, except fuels; 4 - Mineral fuels, lubricants and related materials; 5 - Animal and vegetable oils, fats and waxes; 6 - Chemicals and related products, nes; 7 - Manufactured goods classified chiefly by materials; 8 - Machinery and transport equipment; 9 Miscellaneous manufactured articles; 10 - Commodities and transactions not classified elsewhere in the SITC. 
Table 6 - Density and tariff reduction ( $95^{\text {th }}$ percentile distance)

\begin{tabular}{|c|c|c|c|c|}
\hline & \multicolumn{4}{|c|}{ Dependent variable: } \\
\hline & \multicolumn{4}{|c|}{ Relative density } \\
\hline & 1994 & 1996 & 1998 & 2000 \\
\hline & 1 & 2 & 3 & 4 \\
\hline Tariff of near products & $\begin{array}{c}-1.030^{* * *} \\
(0.234)\end{array}$ & $\begin{array}{l}-0.536^{* *} \\
(0.234)\end{array}$ & $\begin{array}{l}-0.253 \\
(0.219)\end{array}$ & $\begin{array}{l}-0.306 \\
(0.217)\end{array}$ \\
\hline Own tariff & $\begin{array}{c}0.863 \\
(0.579)\end{array}$ & $\begin{array}{c}0.254 \\
(0.607)\end{array}$ & $\begin{array}{c}0.471 \\
(0.572)\end{array}$ & $\begin{array}{c}0.431 \\
(0.585)\end{array}$ \\
\hline 1992 & $\begin{array}{c}-0.114^{* * *} \\
(0.025)\end{array}$ & $\begin{array}{l}-0.048^{*} \\
(0.027)\end{array}$ & $\begin{array}{l}-0.016 \\
(0.026)\end{array}$ & $\begin{array}{l}-0.032 \\
(0.026)\end{array}$ \\
\hline 1994 & $\begin{array}{c}-0.476^{* * *} \\
(0.039)\end{array}$ & $\begin{array}{c}-0.362^{* * *} \\
(0.040)\end{array}$ & $\begin{array}{c}-0.306^{* * *} \\
(0.038)\end{array}$ & $\begin{array}{c}-0.333^{* * *} \\
(0.038)\end{array}$ \\
\hline 1996 & & $\begin{array}{c}-0.746^{* * *} \\
(0.039)\end{array}$ & $\begin{array}{c}-0.692^{* * *} \\
(0.037)\end{array}$ & $\begin{array}{c}-0.718^{* * *} \\
(0.037)\end{array}$ \\
\hline 1998 & & & $\begin{array}{l}-0.052 \\
(0.032)\end{array}$ & $\begin{array}{l}-0.071^{* *} \\
(0.033)\end{array}$ \\
\hline 2000 & & & & $\begin{array}{l}0.079^{* *} \\
(0.033)\end{array}$ \\
\hline Tariff * Beverage/Tobacco & $\begin{array}{l}-0.803 \\
(0.588)\end{array}$ & $\begin{array}{l}-0.157 \\
(0.618)\end{array}$ & $\begin{array}{l}-0.408 \\
(0.584)\end{array}$ & $\begin{array}{l}-0.329 \\
(0.597)\end{array}$ \\
\hline Tariff $*$ Chemicals & $\begin{array}{l}-1.178^{* *} \\
(0.597)\end{array}$ & $\begin{array}{l}-0.213 \\
(0.632)\end{array}$ & $\begin{array}{l}-0.221 \\
(0.600)\end{array}$ & $\begin{array}{l}-0.391 \\
(0.615)\end{array}$ \\
\hline Tariff * NES & $\begin{array}{l}-0.985 \\
(0.902)\end{array}$ & $\begin{array}{l}-0.331 \\
(1.008)\end{array}$ & $\begin{array}{l}-0.337 \\
(0.982)\end{array}$ & $\begin{array}{l}-0.518 \\
(1.023)\end{array}$ \\
\hline Tariff * Crude materials & $\begin{array}{c}0.014 \\
(0.648)\end{array}$ & $\begin{array}{l}1.278^{*} \\
(0.693)\end{array}$ & $\begin{array}{l}1.164^{*} \\
(0.657)\end{array}$ & $\begin{array}{c}0.914 \\
(0.673)\end{array}$ \\
\hline Tariff * Machinery and transport & $\begin{array}{l}-1.354^{* *} \\
(0.593)\end{array}$ & $\begin{array}{l}-0.537 \\
(0.622)\end{array}$ & $\begin{array}{l}-0.416 \\
(0.588)\end{array}$ & $\begin{array}{l}-0.380 \\
(0.600)\end{array}$ \\
\hline Tariff * Manufactures (by materials) & $\begin{array}{l}-1.244^{* *} \\
(0.589)\end{array}$ & $\begin{array}{l}-0.402 \\
(0.622)\end{array}$ & $\begin{array}{l}-0.636 \\
(0.590)\end{array}$ & $\begin{array}{l}-0.804 \\
(0.604)\end{array}$ \\
\hline Tariff * Mineral fuels & $\begin{array}{c}-1.815^{*} \\
(1.030)\end{array}$ & $\begin{array}{l}-0.473 \\
(1.094)\end{array}$ & $\begin{array}{l}-0.525 \\
(1.059)\end{array}$ & $\begin{array}{l}-0.052 \\
(1.091)\end{array}$ \\
\hline Tariff * Miscellaneous manufactures & $\begin{array}{l}-0.327 \\
(0.598)\end{array}$ & $\begin{array}{c}0.764 \\
(0.630)\end{array}$ & $\begin{array}{c}0.427 \\
(0.596)\end{array}$ & $\begin{array}{c}0.464 \\
(0.610)\end{array}$ \\
\hline $\mathrm{N}^{\mathrm{O}}$ of products & 611 & 631 & 641 & 643 \\
\hline Observations & 1,724 & 2,340 & 2,948 & 3,550 \\
\hline $\mathrm{R}^{2}$ & 0.390 & 0.565 & 0.516 & 0.485 \\
\hline Adjusted $R^{2}$ & 0.046 & 0.400 & 0.378 & 0.368 \\
\hline F Statistic & $58.686^{* * *}(\mathrm{df}=12 ; 1101)$ & $169.628^{* * *}(\mathrm{df}=13 ; 1696)$ & $174.713^{* * *}(\mathrm{df}=14 ; 2293)$ & $181.552^{* * *}(\mathrm{df}=15 ; 2892)$ \\
\hline
\end{tabular}


Since different criteria for selecting near products could be used, seven different values of $\phi$ were tested for the same time window considering distinct quantiles in the proximity distribution. The chosen value of the $95^{\text {th }}$ quantile reported in Table 6 comes after the fact that other measures had statistical significance disregarding the policy changes that occurred in 1998 - when tariffs were raised - as can be seen in panel A from Figure 11. It is curious that both significance - panel B presents the t-statistics for the coefficients in A - and magnitude are higher when taking into account more unrelated products. The curiosity comes from the fact that smaller quantiles end up including as "near" products more than 600 goods, as show in panel C for the 7139 SITC classification: piston engine parts, something that Brazil presented comparative advantage in 1994. Such result probably indicates that average tariff change could be actually indicating simultaneous (and spurious) trends for density, that was raising (Figure 9), and tariffs, that were being reduced (Figure 8).

Figure $11-\beta_{\phi}$, t-statistics and number of products per quantile

A

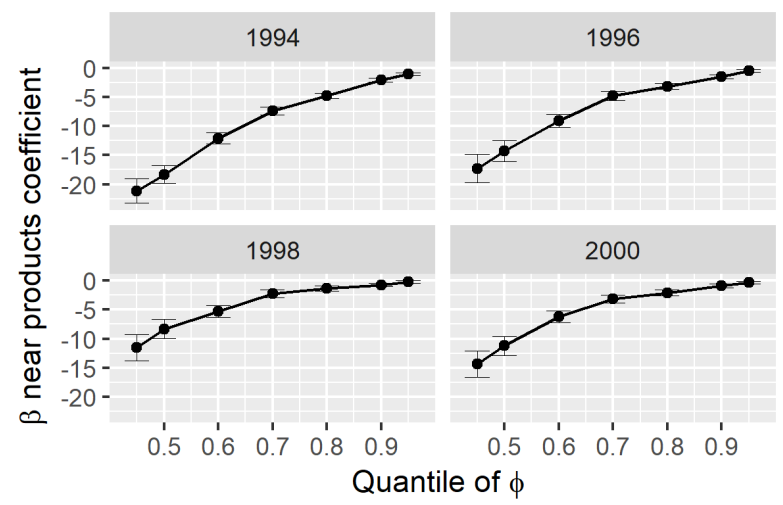

B

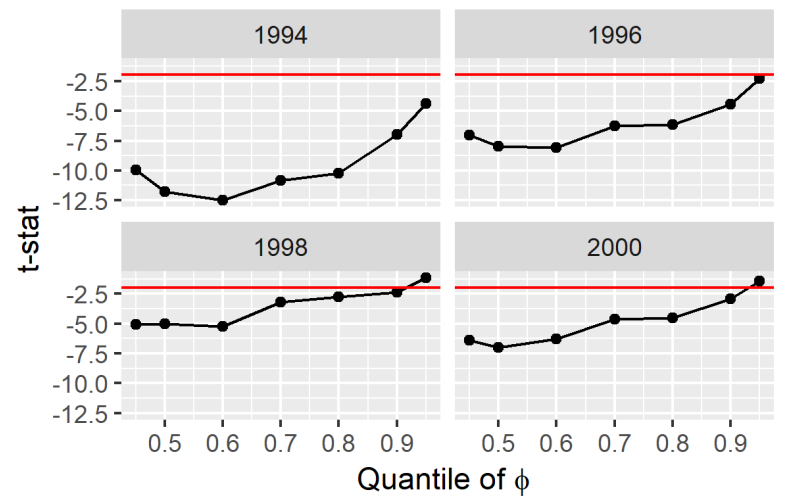

C

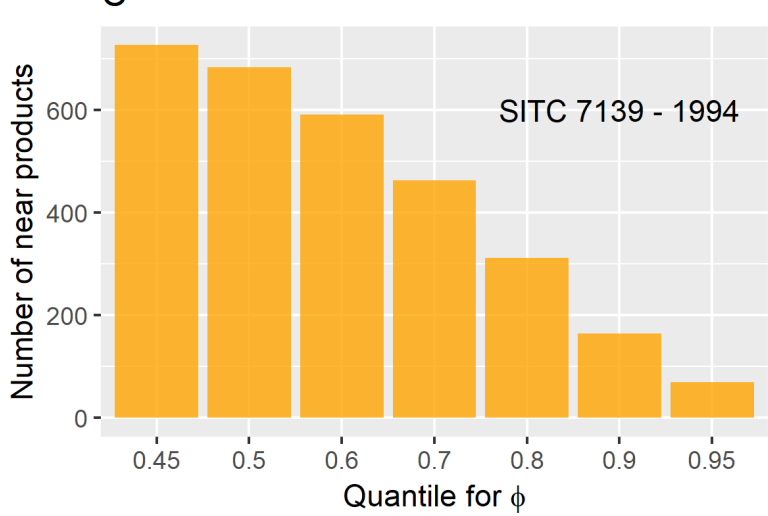

It is noticeable that no Group presents a durable statistical significance pattern when interacted with tariff changes. It is also worth highlighting that only the year of 2000 shows a positive and significant average difference in relation to 1990, the reference year. Such result was already expected given the behavior of the average density in Figure 9 that indicates the year of 2000 as the highest level for the Brazilian measure. Indeed, 
Figure 9 helps to interpret much of the results in Table 6 , since it shows that the average density was raising during the tariff cut period and it was later reversed in the aftermath of the currency reform. The fact that Brazil rose the diversity of its exports in this short period between both reforms is something little discussed and that could raise some new insights. For instance, when grouping all manufactured ${ }^{7}$ products, its exports followed the trend presented in Kupfer (1998): were relatively stable when comparing 1989 (54\%) and 1999 (53\%) and had a maximum at 1993 (56\%), although less pronounced in this dataset.

Some products that were first exported with comparative advantage in 1990 and remained as such for several years afterwards were, actually, the result of great previous investments, such as the aircraft (SITC code 7923) made by Embraer. As Castro (2001) highlights, this was one relevant exception of a manufacture that managed enhancing productivity among industries with higher technological content. However, such technological improvement was not a generalized pattern when comparing goods that were already exported with comparative advantage before the tariff cut reform with those that started being so after it. Both values for the PGI and PRODY variables are only slightly better for those that entered the Brazilian export basket from 1990 onward, meaning that neither growth prospects, nor inequality reducing industries gained relative positions in a significant way.

Table 7 bellow indicates summary statistics for products that started being exported with comparative advantage after 1990 and before 1994 (when only the tariff cut was underway) and presented such relevance for at least six years up to 1998 (when the currency depreciation and the raising of tariffs favored once again the national exports). First column indicates for how many years they were exported with such status, and the last line comprises information for those goods that were already exported with comparative advantage before 1988 (the first year of the trade reforms) and remained as such until 1998. 92 different products were included in this last group and jointly they represented at least $58 \%$ of the Brazilian export value since 1988 and reached its highest proportion in the 1990 (66\%). It is noticeable that there is little difference among all groups considering the average measures used to identify social features associated with each industry. Also, the products that started being exported in those years presented much variation among them. Whereas on one hand Brazil exported trucks and vans (SITC 7821) from 1990 to 1998, which has a low PGI value (37.3) and a high PRODY $(21,683)$, on the other the country became a relevant exporter during the same period of calf leather (SITC 6113), associated with a much higher PGI (48.5) and lower PRODY $(3,398)$.

If we restrict the analysis to the industrialized products classified as Machinery and transport equipment, the larger group among the top 100 complex industries (see Figure 3 ), it becomes even harder to determine the impact of the reforms. The group's share of

\footnotetext{
7 Were included in the manufactured group all chemical and related products (Group 5), manufactured goods classified by material (Group 6), machinery and transport equipment (Group 7) and miscellaneous manufactured products (Group 8).
} 
Table 7 - New exports (RCA) before 1994

\begin{tabular}{c|c|c|c|c|c}
\hline Years $(\mathrm{RCA})$ & $\mathrm{PGI}_{3}$ & $\mathrm{PRODY}_{3}$ & PCI & $\omega$ & No \\
\hline 6 & 40.82 & 15,951 & 0.24 & 0.19 & 22 \\
7 & 40.25 & 15,147 & 0.03 & 0.18 & 13 \\
8 & 40.29 & 15,509 & -0.02 & 0.18 & 17 \\
9 & 39.8 & 15,556 & 0.26 & 0.18 & 18 \\
$1987-98$ & 40.56 & 14,833 & 0.00 & 0.17 & 92 \\
\hline
\end{tabular}

the total export value among the "recently entered industries" (those included in Table 7) fell from near 34\% in 1990 to $29 \%$ in 1992 and then rose steadily up to $60 \%$ by 1998 . Therefore, there was no clear trend of enhancing exports after accessing foreign markets for cheaper and better inputs. The fact that Brazil was able to enlarge the scope of goods exported with comparative advantage right after the liberalization reform was not related to an upgrade in the quality of the newly exported goods - in line with the conclusions in Iootty, Kupfer and Ferraz (2004) about the maintenance of overall manufacturing composition. Considering those goods for which Brazil presented comparative advantage during the whole period (the last line in Table 7 ), it is noticeable that the share of primary products $^{8}$ in total exports remained close to $35 \%$ from 1987 up to 1998. Those evidences of a stable sectoral composition are also confirmed by the average density $(\omega)$ of all five groups shown in Table 7. Not only they have very similar values, but also all "new industries" have an average value slightly higher to the "resilient" group, indicating they were closely related to the capabilities that were already consolidated.

At last, it was excluded from the "recently exported" products in the 1990s all those goods that had already been exported in the 1980s at least once. This last analysis tries to understand which were the industries for which Brazil was firstly able to engage during the liberalization period. Once again it becomes clear that those policy measures were not able to diversify Brazilian capabilities in a sustainable way. By this criteria there were only twelve new industries in the 1990s and, among those, only one remained as relevant exporter until 1998, which was photographic film (SITC 8822). Even though it is an activity related with higher growth prospects, lower inequality and greater complexity, it is clear that, specially when considering a nation's productive structure, one swallow does not make a summer.

Therefore, although the regressions in Table 6 were not very informative about the relation between lowering protection and the creation of new capabilities, it indicated a more diverse export basket that should be considered in greater depth. What the analysis has shown is that there was no significant change in the main features of the industries that Brazil became able to compete in the international market. Those new activities, actually, had similar features to the ones that were already in place. It is relevant to notice,

8 Here including all products classified as food and live animals chiefly for food (Group 0); crude materials, inedible, except fuels (Group 2); animal and vegetable oils, fats and waxes (Group 4). 
notwithstanding, that this industry analysis is unable to assess changes that could have occurred in the quality of goods. The focus here is in the fact that the new industries for which Brazil showed comparative advantage where not related to different social aspects than the ones already established.

\subsection{Commentaries}

This study had the goal to provide an useful dataset for researchers interested in incorporating tariff instruments for the designing of industrial policies. So far, the product space approach has proved to be a relevant tool for understanding how policymakers should guide their resources to foster specific industries given each country's capabilities. However, little effort has been made to design which instruments could be used in the pursue of such objectives. Therefore, this study aimed at constructing an initial dataset for combining considerations over the product space and tariffs. As posed by Akyüz (2009), tariffs should be taken as first order instruments for development strategies and their composition should be altered strategically along the development process for developing countries, aiming to protect industries that are still not able to compete internationally. Similarly to Friedrich List's ladder metaphor, Akyuz defends that the tariff instrument should be used by developing countries as it was by already developed ones (what is good for the goose, must be good to the gander), instead of the horizontal proposals from the World Trade Organization to lower protection for all.

The analysis undertaken for the Brazilian liberalization episode in the 1990s, however, has shown some limitations of the methodology that was implemented to connect policies and the product space. Using the density measure was not much informative, since its behavior was mostly driven by the diversity of exports and had only a spurious relation with the behavior of tariffs themselves. It was not possible to understand the results in Table 6 as the impact of lowering tariffs on Brazilian productive structure, what required analysing further which were the industries for which Brazil gained comparative advantage.

Such analysis allowed to understand that greater diversity was not necessarily due to a process of enhancing Brazilian capabilities. Earlier studies have suggested that productivity was magnified through the input mechanism during the Brazilian reforms in the 1990s (SCHOR, 2004; LISBOA; MENEZES; SCHOR, 2010), however, the analysis that was undertaken here aimed at a different variable: how Brazil was more or less able to engage in industries associated with higher growth prospects and lower inequality. What was seen is that the Brazilian product space did not moved in the direction of industries that could represent such change.

Finally, this study has also raised a concern about how to consider evaluations based on the density measure. This metric has been useful as to depict "low hanging fruits" 
during the development process, indicating which next steps could be taken more firmly. Still, this exercise indicated that this measure is heavily dependent on the diversity of exports (always taken by the comparative advantage criteria). This could suggest, for instance, that density is better used as a compass than a policy objective in itself, since its increase has not a straightforward meaning. 
Appendix 


\section{APPENDIX A - ECI measure and samples}

\section{A.1 Economic and Product Complexity Indexes}

Complexity, as derived by Hausmann and Hidalgo (2014), is measured both for goods and countries through an iterative process responsible for analyzing an adjacency matrix $M_{c, p}$ that has value equals unity if country $c$ is a relevant exporter of product $p$, and zero otherwise. Iterations are made through the following rule for all the years:

$$
\begin{aligned}
& k_{c, N}=\frac{1}{k_{c, 0}} \sum_{p} M_{c, p} k_{p, N-1} \\
& k_{p, N}=\frac{1}{k_{p, 0}} \sum_{c} M_{c, p} k_{c, N-1}
\end{aligned}
$$

and each step of it has a different interpretation. The first country variable $\left(k_{c 1,0}\right)$ represents the diversity of products made by $c 1$, and results form the sum of all elements in line $c 1$ of $M_{c, p}$. Analogously, $k_{p 1,0}$ is obtained summing up all elements in the first column and indicates the ubiquity of $p 1$. Then, as to use informatively the interaction between diversity and ubiquity, A.2 goes as input in A.1 and the same the other way around:

$$
\begin{aligned}
k_{c, N} & =\frac{1}{k_{c, 0}} \sum_{p} M_{c, p} \frac{}{k_{p, 0}} \sum_{c^{\prime}} M_{c^{\prime}, p} k_{c, N-2} \\
& =\sum_{c^{\prime}} k_{c^{\prime}, N-2} \sum_{p} \frac{M_{c, p} M_{c^{\prime}, p}}{k_{c, 0} k_{p, 0}} \\
& =\sum_{c^{\prime}} \widetilde{M}_{c} c^{\prime} k_{c^{\prime}, N-2}
\end{aligned}
$$

where

$$
\widetilde{M}_{c c^{\prime}}=\sum_{p} \frac{M_{c, p} M_{c^{\prime}, p}}{k_{c, 0} k_{p, 0}}
$$

since the largest eigenvalue that solves A.5 is associated with an eigenvector of ones, therefore showing no variance, the chosen vector $(\vec{K})$ is the one associated with the second largest eigenvalue. Finally, the Economic Complexity Index is defined as the normalized vector $\vec{K}$ :

$$
E C I^{1}=\frac{\vec{K}-<\vec{K}>}{s d(\vec{K})}
$$




\section{A.2 Sample for Chapter 1}

Column WW(2003) indicates the year of liberalization for 83 nations as defined by Wacziarg and Welch (2008) and JZ(2008) for 32 among them as set by Ju, Wu and Zeng (2010). "Closed" is attributed to those countries that were classified as closed economies up to 2005, whilst "Always open" is set to those that fill the SW's criteria since 1950. For all countries data ranges from 1964 up to 2005.

\begin{tabular}{|c|c|c|c|c|c|c|c|c|c|c|}
\hline & Country & Region & WW(2003) & $\mathrm{JZ}(2008)$ & Income - 1990 & Country & Region & WW(2003) & $\mathrm{JZ}(2008)$ & Income - 1990 \\
\hline 1 & Australia & Oceania & 1964 & & $\mathrm{H}$ & Netherlands & Europe & 1959 & & $\mathrm{H}$ \\
\hline 2 & New Zealand & Oceania & 1986 & & $\mathrm{H}$ & Norway & Europe & Always open & & $\mathrm{H}$ \\
\hline 3 & Canada & North America & 1952 & & $\mathrm{H}$ & Poland & Europe & 1990 & & LM \\
\hline 4 & United States & North America & Always open & & $\mathrm{H}$ & Portugal & Europe & Always open & & UM \\
\hline 5 & Egypt & Middle East & 1995 & & $\mathrm{~L}$ & Romania & Europe & 1992 & & LM \\
\hline 6 & Iran & Middle East & Closed & & LM & Spain & Europe & 1959 & & $\mathrm{H}$ \\
\hline 7 & Israel & Middle East & 1985 & & $\mathrm{H}$ & Sweden & Europe & 1960 & & $\mathrm{H}$ \\
\hline 8 & Jordan & Middle East & 1965 & & LM & Switzerland & Europe & Always open & & $\mathrm{H}$ \\
\hline 9 & Syria & Middle East & Closed & & LM & United Kingdom & Europe & Always open & & $\mathrm{H}$ \\
\hline 10 & Turkey & Middle East & 1989 & 1985 & LM & China & Asia & Closed & 1998 & $\mathrm{~L}$ \\
\hline 11 & Argentina & Latin America & 1991 & 1991 & LM & Hong Kong & Asia & Always open & & $\mathrm{H}$ \\
\hline 12 & Bolivia & Latin America & 1985 & & LM & India & Asia & Closed & 1997 & $\mathrm{~L}$ \\
\hline 13 & Brazil & Latin America & 1991 & 1993 & UM & Indonesia & Asia & 1970 & 1996 & $\mathrm{~L}$ \\
\hline 14 & Chile & Latin America & 1976 & 1992 & LM & Japan & Asia & 1964 & & $\mathrm{H}$ \\
\hline 15 & Colombia & Latin America & 1986 & 1992 & LM & Malaysia & Asia & 1963 & 1995 & LM \\
\hline 16 & Costa Rica & Latin America & 1986 & 1987 & LM & Pakistan & Asia & 2001 & 2000 & $\mathrm{~L}$ \\
\hline 17 & Dominican Republic & Latin America & 1992 & & LM & Philippines & Asia & 1988 & 1999 & LM \\
\hline 18 & Ecuador & Latin America & 1991 & 1992 & LM & Singapore & Asia & 1965 & & $\mathrm{H}$ \\
\hline 19 & El Salvador & Latin America & 1989 & & LM & South Korea & Asia & 1968 & & UM \\
\hline 20 & Guatemala & Latin America & 1988 & 1988 & LM & Sri Lanka & Asia & 1991 & 1998 & $\mathrm{~L}$ \\
\hline 21 & Honduras & Latin America & 1991 & 1992 & $\mathrm{~L}$ & Thailand & Asia & Always open & 2000 & LM \\
\hline 22 & Jamaica & Latin America & 1989 & 2000 & LM & Algeria & Africa & Closed & & LM \\
\hline 23 & Mexico & Latin America & 1986 & 1987 & UM & Angola & Africa & Closed & & LM \\
\hline 24 & Nicaragua & Latin America & 1991 & 1992 & LM & Cameroon & Africa & 1993 & 1994 & LM \\
\hline 25 & Panama & Latin America & 1996 & & LM & Ethiopia & Africa & 1996 & & $\mathrm{~L}$ \\
\hline 26 & Paraguay & Latin America & 1989 & 1986 & LM & Gabon & Africa & Closed & & UM \\
\hline 27 & Peru & Latin America & 1991 & 1991 & LM & Ghana & Africa & 1985 & 1992 & $\mathrm{~L}$ \\
\hline 28 & Trinidad and Tobago & Latin America & 1992 & & UM & Ivory Coast & Africa & 1994 & & LM \\
\hline 29 & Uruguay & Latin America & 1990 & 1994 & UM & Kenya & Africa & 1993 & 2000 & $\mathrm{~L}$ \\
\hline 30 & Venezuela & Latin America & 1996 & 1992 & UM & Madagascar & Africa & 1996 & & $\mathrm{~L}$ \\
\hline 31 & Albania & Europe & 1992 & & LM & Mauritania & Africa & 1995 & 2000 & $\mathrm{~L}$ \\
\hline 32 & Austria & Europe & 1960 & & $\mathrm{H}$ & Morocco & Africa & 1984 & 1997 & LM \\
\hline 33 & Belgium & Europe & 1959 & & $\mathrm{H}$ & Mozambique & Africa & 1995 & & $\mathrm{~L}$ \\
\hline 34 & Bulgaria & Europe & 1991 & & LM & Nigeria & Africa & Closed & 1987 & $\mathrm{~L}$ \\
\hline 35 & Denmark & Europe & 1959 & & $\mathrm{H}$ & Republic of the Congo & Africa & Closed & & LM \\
\hline 36 & Finland & Europe & 1960 & & $\mathrm{H}$ & Senegal & Africa & Closed & & LM \\
\hline 37 & France & Europe & 1959 & & $\mathrm{H}$ & South Africa & Africa & 1991 & & UM \\
\hline 38 & Germany & Europe & 1959 & & $\mathrm{H}$ & Tanzania & Africa & 1995 & & $\mathrm{~L}$ \\
\hline 39 & Greece & Europe & 1959 & & UM & Togo & Africa & Closed & & $\mathrm{L}$ \\
\hline 40 & Hungary & Europe & 1990 & & UM & Tunisia & Africa & 1989 & 1993 & LM \\
\hline 41 & Ireland & Europe & 1966 & & $\mathrm{H}$ & Zambia & Africa & 1993 & 1996 & $\mathrm{~L}$ \\
\hline 42 & Italy & Europe & 1959 & & $\mathrm{H}$ & & & & & \\
\hline
\end{tabular}

\section{A.3 Additional sample Section 1.4 .3}

\begin{tabular}{|c|c|c|c|c|c|c|c|c|c|c|}
\hline & Country & Region & WW(2003) & $\mathrm{JZ}(2008)$ & Income - 1990 & Country & Region & WW(2003) & $\mathrm{JZ}(2008)$ & Income - 1990 \\
\hline 1 & Haiti & Latin America & Closed & & $\mathrm{L}$ & Mauritius & Africa & 1968 & & LM \\
\hline 2 & Nepal & Asia & 1991 & 1993 & $\mathrm{~L}$ & Niger & Africa & 1994 & & $\mathrm{~L}$ \\
\hline 3 & Benin & Africa & 1990 & 1993 & $\mathrm{~L}$ & Uganda & Africa & 1988 & 1997 & $\mathrm{~L}$ \\
\hline 4 & Burkina Faso & Africa & 1998 & & $\mathrm{~L}$ & Malawi & Africa & Closed & & $\mathrm{L}$ \\
\hline 5 & Democratic Republic of the Congo & Africa & Closed & & $\mathrm{L}$ & Zimbabwe & Africa & Closed & & LM \\
\hline 6 & Mali & Africa & 1988 & 1991 & $\mathrm{~L}$ & Liberia & Africa & Closed & & $\mathrm{L}$ \\
\hline
\end{tabular}




\section{APPENDIX B - Methodology}

\section{B.1 Connecting tariffs and the SITC codes}

The code below is responsible for linking products listed in the Observatory of Economic Complexity, using the SITC Rev. 2 classification, and those described by the Harmonized System 6-digit - used in the tariff description for the TRAINS dataset. The procedure required matching three different tables: SITC Rev. 2 product name and code from OEC (called in the code by cod_sitc) ${ }^{1}$, the code correspondence table between SITC Rev. 2 and HS 2017 from UNTAC ${ }^{2}$ (sitc2_hs17) and the UN Commodity Classification Table for all codes and products ${ }^{3}$ (hs_desc).

OEC uses 988 different codes, while the UN Correspondence table has 1476 different classifications. Since the latter was the one used to connect the SITC codes with the HS, data from the OEC was matched using codes correspondence, or the commodity description available in the UN Commodity Classification Table. For instance, eleven products in the OEC data had the same description, for those it was chosen to let the lower value of the code (the one with less information) as the simpler category, attributing to the other a correspondent name from the SITC in the UN Commodity Classification Table. Those were the case for the codes below.

\# Copper <- "Copper and copper alloys, refined or not, unwrought

cod_sitc $[$ cod_sitc $\$$ sitc $=6821$,$] \$name <-$ "Copper and copper

alloys, refined or not, unwrought"

\# Miscellaneous manufactured articles $<-$ Miscellaneous

manufactured articles, nes

cod_sitc [cod_sitc\$sitc $=8900$,$] \$name <-$ "Miscellaneous

manufactured articles, nes"

\# Glassware <- Glassware (other than heading 66582), for indoor decoration

cod_sitc [cod_sitc\$sitc $=6652$,$] \$name <-$ "Glassware (other than heading 66582), for indoor decoration"

\# Pottery <- Articles of domestic or toilet purposes, of other kind of pottery

1 Available at $<$ https://oec.world/en/resources/data/ $>$.

2 Available at $<$ https://unstats.un.org/unsd/trade/classifications/correspondence-tables.asp $>$.

3 Available at $\quad<$ https://unstats.un.org/unsd/tradekb/Knowledgebase/50039/ UN-Comtrade-Reference-Tables>. 
cod_sitc $[$ cod_sitc\$sitc $=6665$,$] \$name <-$ "Articles of domestic

or toilet purposes, of other kind of pottery"

\# Nickel <- Nickel and nickel alloys, unwrought

cod_sitc[cod_sitc\$sitc $=6831$,$] \$name <-$ "Nickel and nickel

alloys , unwrought"

\# Zinc $<-$ Zinc and zinc alloys worked

cod_sitc[cod_sitc\$sitc $=6863$,$] \$name <-$ "Zinc and zinc alloys worked"

\# Tin $<-$ Tin ores and concentrates

cod_sitc[cod_sitc\$sitc $=2876$,$] \$name <-$ "Tin ores and concentrates"

\# Rice $<-$ Rice in the husk or husked, but not farther prepared cod_sitc [cod_sitc\$sitc $=421$,$] \$name <-$ "Rice in the husk or husked, but not farther prepared"

\# Cotton $<-$ Cotton, carded or combed

cod_sitc $[$ cod_sitc\$sitc $=2634$,$] \$name <-$ "Cotton, carded or combed"

\# Spices <- Spices, except pepper and pimento

cod_sitc $[$ cod_sitc\$sitc $=752$,$] \$name <-$ "Spices, except pepper and pimento"

\# Preserved meat $<-$ Meat and edible meat offal, nes, in brine, dried, salted or smoked

cod_sitc $[$ cod_sitc\$sitc $=129$, \$ \$name $<-$ "Meat and edible meat offal, nes, in brine, dried, salted or smoked"

Next the code uses the conversion table as reference and a step matrix using different matches in each case. The final table connects 6139 products in the Harmonized System classification with 801 codes in the OEC classification table.

\# 1st Step: creates HS Level 2 and 4 and adds descriptions for products

conversion <- left_join (rbind ( $\operatorname{sitc} 2 \_$hs 17 , sitc2_hs $17 \% \%$ \# Attribute SITC

Level 1 for HS Level 2 mutate ('From HS $2017^{\prime}=$ substr('

From HS 2017', 1, 2),

'To SITC Rev. 2'= substr

('To SITC Rev. 2', 1,

1)) $\% \%$

subset (! duplicated (.\$'From HS

$\left.\left.2017^{6}\right)\right)$, 
sitc2_hs $17 \% \%$ \# Attribute SITC

Level 2 for HS Level 4 mutate( 'From HS 2017' = substr ('

From HS 2017', 1, 4),

'To SITC Rev. 2'= substr

('To SITC Rev. 2', 1,

2)) $\% \%$

subset (! duplicated (.\$'From HS $\left.\left.\left.2017^{\prime}\right)\right)\right)$,

select(filter(hs_desc, Classification $=$

"S2"), Code, Description),

by $=\mathrm{c}("$ To SITC Rev. 2" = "Code" $) \% \%$

mutate( Description = toupper(Description ) $\% \%$

left_join (select (cod_sitc, -id) $\% \%$

mutate $($ name $=$ toupper $($ name $)), \quad b y=c("$ Description $"=$ "name")) $\% \%$

select (-Description) $\% \%$

left_join(select(filter(hs_desc, Classification $=$ "S2"), Code

, Description),

$$
\text { by }=\mathrm{c}(\text { "To SITC Rev. 2" = "Code" }))
$$

\# 2nd step: adds "00" to OEC SITC lower than 1000 (primary products )

step <- subset (conversion, is na(sitc) \& startsWith("To SITC Rev

. $\left.\left.2^{6}, " 00 "\right)\right) \% \%$

select $(-\operatorname{sitc}) \% \%$

left_join ( select (mutate (cod_sitc,

$\operatorname{cod}$.sitc $=$ stringr::str_c("00", cod_sitc $\$$ sitc) ), $\operatorname{cod}$. sitc, sitc), by $=\mathrm{c}("$ To SITC Rev. $2 "=" \operatorname{cod}$. sitc $"))$

conversion [is . na (conversion $\$$ sitc) \& startsWith (conversion $\$$ "To SITC Rev. 2', "00"),] \$sitc <- step\$sitc

\# Categories not identified: live bovine (00119) and live goat (00122)

\# cod_sitc: bovine $(00119)<-11$

conversion\$sitc [conversion\$ "To SITC Rev. $\left.2^{\prime}=" 00119 "\right]<-" 11$ "

\# cod_sitc: goat $(00122)<-12$ 
conversion $\$$ sitc [conversion $\$$ "To SITC Rev. 2" $\left.=" 00122^{\prime \prime}\right]<-" 12^{\prime \prime}$

\# 3rd step: adds "0" to OEC SITC and removes the fifth digit

from column 'To SITC Rev. 2' in the Correspondence Table step $<-$ subset (conversion, is na(sitc) \& startsWith("To SITC Rev

. 2 ,, $0 ")) \% \%$

select $(-\operatorname{sitc}) \% \%$

mutate $(\operatorname{cod}$. sitc $=\operatorname{substr}(. \$$ To SITC Rev. 2', 1,4$)) \% \%$

left_join(select(mutate(cod_sitc, cod.sitc $=$ stringr::str_c

$\left.\left(" 0 ", \operatorname{cod}{ }_{-} \operatorname{sitc} \$ \operatorname{sitc}\right)\right), \operatorname{cod} \cdot \operatorname{sitc}$, sitc $\left.)\right)$

conversion [is.na (conversion $\$$ sitc) \& startsWith (conversion $\$$ "To

SITC Rev. 2', "0"),]\$sitc $<-$ step $\$$ sitc

\# 4th step: remove "0" as last digit for wrongly defined OEC

SITC

step $<-$ subset (conversion, is na(sitc) \& startsWith("To SITC Rev

. 2 , " $0 ")) \% \%$

select $(-$ sitc ) $\% \%$

mutate $\left(\operatorname{cod}\right.$. sitc $=\operatorname{str} \_c(\operatorname{substr}(. \$$ To SITC Rev. 2', 2, 3), "0")

) $\% \%$

left_join ( select (mutate(cod_sitc,

$\operatorname{cod}$. sitc $=$ as. character $\left(\operatorname{cod} \_\right.$sitc $\$$ sitc $)$

)$, \operatorname{cod} \cdot \operatorname{sitc}, \operatorname{sitc})) \% \%$

select $(-\operatorname{cod} \cdot \operatorname{sitc})$

conversion [is.na (conversion $\$$ sitc) \& startsWith (conversion $\$$ "To

SITC Rev. 2', "0"),] \$sitc <- step\$sitc

\# 5th step: match identical codes in both tables

step $<-$ subset (conversion, is na(sitc)) $\% \%$

select $(-\operatorname{sitc}) \% \%$

mutate("To SITC Rev. $2^{\prime}=$ as.numeric('To SITC Rev. 2')) $\% \%$

left_join (select (cod_sitc, - - c(id, name) $) \% \%$

mutate $(\operatorname{cod} . \operatorname{sitc}=\operatorname{sitc}), \quad b y=c("$ To SITC Rev. $2 "="$ $\left.\left.\operatorname{cod} \cdot \operatorname{sit} c^{\prime \prime}\right)\right)$

conversion [is.na (conversion $\$$ sitc $),$ ] $\$$ sitc $<-$ step $\$$ sitc 
\# 6th step: multiply codes by 10 as to find OEC SITC that ends with "0"

step $<-$ subset (conversion, is na(sitc)) $\% \%$

select $(-$ sitc $) \% \%$

mutate(cod.sitc $=$ as.integer (.\$'To SITC Rev. 2') * 10)\%\%

left_join (select (cod_sitc, $-\mathrm{c}(\mathrm{id}$, name $)) \% \%$

$\operatorname{mutate}(\operatorname{cod} \cdot \operatorname{sit} \mathrm{c}=\operatorname{sitc}))$

conversion [is.na (conversion $\$$ sitc $),$ ] $\$$ sitc $<-$ step $\$$ sitc

\# 7th step: remove last digit from 5-digit codes

step $<-$ subset (conversion, is . na(sitc)) $\% \%$

select $(-\operatorname{sitc}) \% \%$

mutate $\left(\operatorname{cod}\right.$. sitc $=\operatorname{substr}\left(. \$\right.$ To SITC Rev. $\left.\left.2^{\prime}, 1,4\right)\right) \% \%$

left_join (select (cod_sitc, -c (id, name)) $\% \%$

mutate $(\operatorname{cod} . \operatorname{sitc}=$ as. character $(\operatorname{sitc}))) \# \% \%$

\# $\quad \operatorname{summarise}(\mathrm{n}()-\operatorname{sum}($ is.na $(\operatorname{sitc})))$

conversion [is.na (conversion $\$$ sitc $),$ ] $\$$ sitc $<-$ step $\$$ sitc

\# Non-matched codes: UN Commodity Description <- OEC

\# Miscellaneous non-ferrous base metals, employed in metallurgy

$<-$ Unwrought Base Metals

conversion [conversion\$ "To SITC Rev. $2^{\prime}=$ "689",]\$sitc <- "6899"

\# Food-processing machines (non-domestic) and parts <-

Miscellaneous Food-Processing Machinery

conversion [conversion\$ "To SITC Rev. $2^{\prime}=" 727 "$ "] \$sitc $<-" 7272$ "

\# Electric power machinery, and parts thereof, nes <-

Miscellaneous Power Machinery

conversion [conversion $\$$ "To SITC Rev. $2^{\prime}=" 771$ ", $\$$ sitc $<-" 7712^{\prime \prime}$

\# Food and live animals chiefly for food $<-$ Live animals chiefly

for food

conversion [conversion $\$$ To SITC Rev. $2^{6}=0$, ] $\$$ sitc $<-10$

\# Animals, live, nes, (including zoo animals, pets, insects, etc

) $<-$ Miscellaneous Live Animals

conversion [conversion\$ ${ }^{6}$ To SITC Rev. $2^{\prime}=94$, , $\$$ sitc $<-9410$

\# Fish, crustacean and molluscs, and preparations thereof $<-$

Fish, crustaceans and molluscs, misc

conversion [conversion $\$$ 'To SITC Rev. $2^{6}=03$, , \$sitc $<-370$ 
\# Miscellaneous edible products and preparations <-

Miscellaneous Edibles

conversion [conversion\$ 'To SITC Rev. $2^{6}=09$, , \$sitc $<-980$

\# Sugar, sugar preparations and honey <- Sugar and honey

conversion [conversion\$ 'To SITC Rev. $2^{6}=06$, , \$sitc $<-610$

\# Coin (other than gold coin), not being legal tender $<-$ Non-

Gold Coin

conversion [conversion\$ 'To SITC Rev. $2^{6}=96$, , \$sitc $<-9610$

\# Armoured fighting vehicles, war firearms, ammunition, par <-

Armoured Vehicles, Firearms and Ammunition

conversion [conversion\$ 'To SITC Rev. $2^{6}=95$, , \$sitc $<-9510$

\# Gold, non-monetary (excluding gold ores and concentrates) <-

Gold

conversion [conversion\$ $\$$ To SITC Rev. $2^{6}=97$, ] \$sitc $<-9710$

\# Paper, paperboard, and articles of pulp, of paper or of

paperboard $<-$ Paper and paperboard

conversion [conversion\$'To SITC Rev. $2^{6}=64$, , \$sitc $<-6410$

\# Travel goods, handbags and similar containers $<-$ Luggage

conversion [conversion\$ 'To SITC Rev. $2^{6}=83$,] \$sitc $<-8310$

\# Petroleum, petroleum products and related materials <-

Petroleum products

conversion [conversion\$ 'To SITC Rev. $2^{6}=33$, ] \$sitc $<-3300$

\# Feeding stuff for animals (not including unmilled cereals) <-

Feed for animals

conversion [conversion $\$$ 'To SITC Rev. $2^{\prime}=08$, , \$sitc $<-810$

This last part connects 2-digit HS codes for which there was no previous match.

\# 1st step:

conversion $2<-$ sitc 2 _hsi7 \%\% \# Defines SITC Level 1 for HS

Level 2

mutate ('From HS 2017' = substr('From HS 2017', 1, 2),

'To SITC Rev. $2^{6}=\operatorname{substr}\left({ }^{\prime}\right.$ To SITC Rev. 2', 1, 4)) \%\%

subset (! duplicated (.)) $\% \%$

filter ('From HS 2017' \%in\% filter (conversion, is na(sitc)) $\$$ '

From HS 2017') \% \%

left_join(select(filter(hs_desc, Classification $=$ "S2"), Code

, Description),

by $=\mathrm{c}("$ To SITC Rev $\cdot 2 "=$ "Code" $) \% \%$

mutate $($ Description = toupper $($ Description $)) \% \%$

left_join (select (cod_sitc, -id) $\% \%$ 


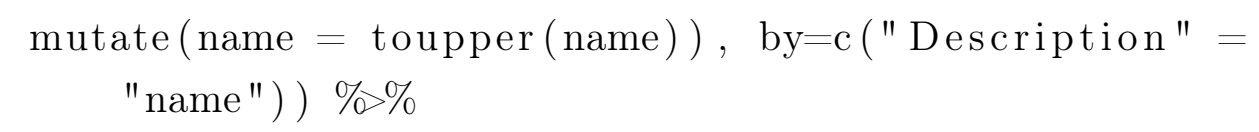

select (-Description) $\% \%$

left_join(select(filter(hs_desc, Classification $=$ "S2"), Code , Description),

$$
\text { by }=\text { c ("To SITC Rev. 2" = "Code") })
$$

\# 2nd step: match with OEC codes

step $<-$ conversion $2 \% \%$

filter (is.na(sitc)) $\% \%$

select $(-\operatorname{sitc}) \% \%$

mutate("To SITC" = as.numeric("To SITC Rev. 2")) \%\%

left_join (cod_sitc $\% \%$ mutate("To SITC" = sitc) $\% \%$ select ("To SITC', sitc)) $\% \%$

select (- 'To SITC')

conversion $2[$ is . na ( conversion $2 \$$ sitc $)] \$,$$ sitc <-$ step $\$$ sitc

\# 3rd step :

step $<-\quad$ subset (conversion 2, is.na( $\operatorname{sitc})) \% \%$

select $(-\operatorname{sitc}) \% \%$

left_join (conversion $\% \%$ subset (! duplicated (.\$'To SITC Rev.

$\left.\left.2^{6}\right)\right) \%$ select ('To SITC Rev. 2', sitc))

conversion $2[$ is.na $($ conversion $2 \$$ sitc $)$,$] sitc <-$ step $\$$ sitc

\# Define a single correspondence table

conversion $<-$ rbind (conversion $\% \%$ filter (! is.na (sitc)) conversion 2 ) 


\section{Bibliography}

ACEMOGLU, D.; JOHNSON, S.; ROBINSON, J. A. The colonial origins of comparative development: An empirical investigation. American Economic Review, v. 91, n. 5, p. 1369-1401, December 2001.

ACEMOGLU, D.; JOHNSON, S.; ROBINSON, J. A. Reversal of fortune: Geography and institutions in the making of the modern world income distribution. The Quarterly Journal of Economics, v. 117, n. 4, p. 1231-1294, 2002.

ACEMOGLU, D.; ROBINSON, J. A. Why Nations Fail: The Origins of Power, Prosperity and Poverty. 1st. ed. New York: Crown, 2012.

AGHION, P.; HOWITT, P. Appropriate growth policy: A unifying framework. journal of the european economic. Journal of the European Economic, v. 4, n. 2-3, p. 269-314, June 2006.

AGOSIN, M. R.; AlvareZ, R.; BRAVO-ORTEGA, C. Determinants of Export Diversification Around the World: 1962-2000. The World Economy, v. 35, n. 3, p. 295-315, March 2012.

AKYüZ, Y. Industrial tariffs, international trade, and development. In: Industrial Policy and Development: The Political Economy of Capabilities Accumulation. Oxford: Oxford University Press, 2009. p. 144-174.

ALESSANDRINI, M.; FATTOUH, B.; FERRARINI, B.; SCARAMOZZINO, P. Tariff liberalization and trade specialization: Lessons from India. Journal of Comparative Economics, v. 39, n. 4, p. 499-513, 2011.

BALASSA, B. Comparative advantage in manufactured goods: A reappraisal. The Review of Economics and Statistics, v. 68, n. 2, p. 315-19, 1986.

BAS, M.; PAUNOV, C. Input-quality upgrading from trade liberalization: evidence on firm product growth and employment. Forthcoming, March 2018.

BEKAERT, G.; HARVEY, C. R.; LUNDBLAD, C. Does financial liberalization spur growth? Journal of Financial Economics, v. 77, n. 1, p. 3-55, July 2005.

BIELSCHOWSKY, R.; ABICALIL, M.; OLIVEIRA, C. d.; SOARES, S.; WOHLERS, M. Formação de capital no ambiente das reformas econômicas brasileiras dos anos 1990: Uma abordagem setorial. In: Brasil - Uma década em transição. Rio de Janeiro: Campus, 2000. p. 143-181.

BILLMEIER, A.; NANNICINI, T. Assessing Economic Liberalization Episodes: A Synthetic Control Approach. The Review of Economics and Statistics, v. 95, n. 3, p. 983-1001, July 2013.

BLUNDELL, R.; BOND, S. Initial conditions and moment restrictions in dynamic panel data models. Journal of Econometrics, v. 87, n. 1, p. 115-143, August 1998.

BOSCHMA, R.; CAPONE, G. Institutions and diversification: Related versus unrelated diversification in a varieties of capitalism framework. Research Policy, v. 44, p. 1902-1914, 122015.

BRENCK, C.; CARVALHO, L. Limites para o crescimento com mudança estrutural no brasil do século xxi. In: Alternativas para o desenvolvimento brasileiro - 
Novos horizontes para a mudança estrutural com igualdade. Santiago: ECLAC, 2019. p. $163-180$.

CADOT, O.; CARRERE, C.; STRAUSS-KAHN, V. Export diversification: What's behind the hump? The Review of Economics and Statistics, v. 93, n. 2, p. 590-605, 2011. CARVAlHO, L. Diversificação ou especialização: uma análise do processo de mudança estrutural da indústria brasileira nas últimas décadas. Rio de Janeiro, RJ: $31^{\mathrm{O}}$ Prêmio BNDES de Economia, 2010.

CARVALHO, L.; KUPFER, D. Diversificação ou especialização: uma análise do processo de mudança estrutural da indústria brasileira. Revista de Economia Política, v. 31, n. 4, p. 618-637, 102011.

CASTRO, A. B. d. A reestruturção industrial brasileiras nos anos 90. uma interpretação. Revista de Economia Política, v. 21, n. 3, p. 3-26, 072001.

CHERIF, R.; HASANOV, F. The Return of the Policy That Shall Not Be Named: Principles of Industrial Policy. IMF, 2019. (IMF Working Papers, 19/74).

FEENSTRA, R. C.; INKLAAR, R.; TIMMER, M. P. The next generation of the penn world table. American Economic Review, v. 105, n. 10, p. 3150-82, October 2015.

FELIPE, J.; MEHTA, A.; RHEE, C. Manufacturing Matters...but It's the Jobs That Count. [S.l.], 2014.

FERRARINI, B.; SCARAMOZZINO, P. Production complexity, adaptability and economic growth. Structural Change and Economic Dynamics, v. 37, p. 52 - 61, 2016.

FIRAT, D. IMF conditionality and trade structure: what did structural adjustment programs really adjust? Forthcoming, February 2020.

FORTUNATO, P.; RAZO, C.; VROLIJK, K. Operationalizing the Product Space: A Road Map to Export Diversification. Geneva, 2015. (UNCTAD Discussion Papers).

FRANCO, G. H. B. O desafio brasileiro: ensaios sobre desenvolvimento, globalização e moeda. 3rd. ed. São Paulo: Editora 34, 1999.

FREIRE, C. Economic diversification: A model of structural economic dynamics and endogenous technological change. Structural Change and Economic Dynamics, v. 49, p. $13-28,2019$.

GALA, P.; CAMARGO, J.; MAGACHO, G.; ROCHA, I. Sophisticated jobs matter for economic complexity: An empirical analysis based on input-output matrices and employment data. Structural Change and Economic Dynamics, v. 45, p. 1-8, jun 2018.

GALA, P.; ROCHA, I.; MAGACHO, G. The structuralist revenge: economic complexity as an important dimension to evaluate growth and development. Brazilian Journal of Political Economy, Centro de Economia Política, v. 38, n. 2, p. 219-236, jun 2018.

GALBRAITH, J. K.; HALBACH, B.; MALINOWSKA, A.; SHAMS, A.; ZHANG, W. The UTIP Global Inequality Datasets: 1963-2008. UNU-WIDER, 2015. (WIDER Working Paper Series, 019).

GIAVAZZI, F.; TABELLINI, G. Economic and political liberalizations. Journal of Monetary Economics, v. 52, n. 7, p. 1297-1330, 2005.

GOLDBERG, P.; KHANDELWAL, A.; PAVCNIK, N.; TOPALOVA, P. Imported intermediate inputs and domestic product growth: Evidence from india. The Quarterly Journal of Economics, v. 125, n. 4, p. 1727-1767, 2010. 
HARTMANN, D.; BEZERRA, M.; PINHEIRO, F. L. Identifying smart strategies for economic diversification and inclusive growth in developing economies: The case of Paraguay. Stuttgart, 2019.

HARTMANN, D.; GUEVARA, M. R.; JARA-FIGUEROA, C.; ARISTARÁN, M.; HIDALGO, C. A. Linking Economic Complexity, Institutions, and Income Inequality. World Development, Pergamon, v. 93, p. 75-93, may 2017.

HARTMANN, D.; JARA-FIGUEROA, C.; GUEVARA, M.; SIMOES, A.; HIDALGO, C. A. The structural constraints of income inequality in Latin America. [S.1.], 2017.

HAUSMANN, R.; HIDALGO, C. The Atlas of Economic Complexity: Mapping Paths to Prosperity. 1. ed. Boston: The MIT Press, 2014.

HAUSMANN, R.; HWANG, J.; RODRIK, D. What you export matters. Journal of Economic Growth, v. 12, n. 1, p. 1-25, March 2007.

HIDALGO, C.; KLINGER, B.; BARABASI, A.-L.; HAUSMANN, R. The product space conditions the development of nations. Science (New York, N.Y.), v. 317, p. 482-7, 08 2007.

HIDALGO, C. A.; HAUSMANN, R. The building blocks of economic complexity. Proceedings of the National Academy of Sciences of the United States of America, National Academy of Sciences, v. 106, n. 26, p. 10570-5, jun 2009.

HIRSCHMAN, A. Strategy of Economic Development. 1st. ed. New Haven: Yale University Press, 1958.

IMBS, J.; WACZIARG, R. Stages of Diversification. American Economic Review, v. 93, n. 1, p. 63-86, March 2003.

IOOTTY, M.; KUPFER, D.; FERRAZ, J. C. Industrial competitiveness in Brazil ten years after economic liberalization. Revista CEPAL, April 2004.

JU, J.; WU, Y.; ZENG, L. The Impact of Trade Liberalization on the Trade Balance in Developing Countries. IMF Staff Papers, v. 57, n. 2, p. 427-449, June 2010.

KUME, H.; PIANI, G.; SOUZA, C. F. B. S. A política brasileira de importação no período 1987-98: Descrição e avaliação. In: A Abertura Comercial Brasileira nos Anos 1990: Impactos sobre Emprego e Salário. Rio de Janeiro: IPEA, 2003. p. 9 - 38.

KUPFER, D. Trajetórias da reestruturação da indústria brasileira após a abertura e a estabilização. Doctoral Thesis — Federal University of Rio de Janeiro, 1998.

LI, X. Trade liberalization and real exchange rate movement. IMF Staff Papers, Palgrave Macmillan Journals, v. 51, n. 3, p. 553-584, 2004.

LIN, J.; CHANG, H.-J. Should industrial policy in developing countries conform to comparative advantage or defy it? In: . New Structural Economics : A Framework for Rethinking Development and Policy. Washington DC: The World Bank, 2012. p. $113-139$.

LISBOA, M.; MENEZES, N.; SCHOR, A. The effects of trade liberalization on productivity growth in brazil: Competition or technology? Revista Brasileira de Economia, v. 64, n. 3, p. 277-289, 2010.

MAKHLOUF, Y.; KELLARD, N.; VINOGRADOV, D. Trade openness, export diversification, and political regimes. Economics Letters, v. 136, n. C, p. 25-27, 2015.

MARTInCUS, C. V.; GóMEZ, S. M. Trade Policy and Export Diversification: What Should Colombia Expect from the FTA with the United States. [S.1.], 2011. 
MUEnDLER, M.-A. Trade, Technology and Productivity: A Study of Brazilian Manufacturers 1986-1998. [S.1.], 2004. (CESifo Working Paper).

OSAKWE, P. N.; SANTOS-PAUlinO, A. U.; DOGAN, B. Trade dependence, liberalization, and exports diversification in developing countries. Journal of African Trade, v. 5, n. 1, p. $19-34,2018$.

PARTEKA, A.; TAMBERI, M. Product diversification, relative specialisation and economic development: Import-export analysis. Journal of Macroeconomics, v. 38, n. PA, p. 121-135, 2013.

PINHEIRO, F. L.; ALSHAMSI, A.; HARTMANN, D.; BOSCHMA, R.; HIDALGO, C. Shooting Low or High: Do Countries Benefit from Entering Unrelated Activities? [S.l.], 2018.

RODRíGUEZ, F.; RODRIK, D. Trade policy and economic growth: A skeptic's guide to the cross-national evidence. In: NBER Macroeconomics Annual 2000, Volume 15. [S.1.]: National Bureau of Economic Research, Inc, 2001. p. 261-338.

ROMERO, J.; SILVEIRA, F. Mudança estrutural e complexidade econômica: identificando setores promissores para o desenvolvimento dos estados brasileiros. In: - Alternativas para o desenvolvimento brasileiro - Novos horizontes para a mudança estrutural com igualdade. Santiago: ECLAC, 2019. p. 137-160.

ROODMAN, D. How to do xtabond2: An introduction to difference and system gmm in stata. Stata Journal, v. 9, n. 1, p. 86-136, 2009.

ROS, J. Rethinking Economic Development, Growth, and Institutions. 1st. ed. Oxford: Oxford University Press, 2013. 469 p.

RUGITSKY, F. Questão de estilo: a mudança estrutural para a igualdade e seus desafios. In: __. Alternativas para o desenvolvimento brasileiro - Novos horizontes para a mudança estrutural com igualdade. Santiago: ECLAC, 2019. p. 75-96.

SACHS, J. The age of sustainable development. New York: Columbia University Press, 2015.

SACHS, J. D.; WARNER, A. Economic reform and the process of global integration. Brookings Papers on Economic Activity, Brookings Institution Press, v. 1995, n. 1, p. 1-118, 1995.

SCHOR, A. Heterogeneous productivity response to tariff reduction. evidence from brazilian manufacturing firms. Journal of Development Economics, v. 75, n. 2, p. 373-396, 2004.

WACZIARG, R.; WELCH, K. H. Trade Liberalization and Growth: New Evidence. The World Bank Economic Review, v. 22, n. 2, p. 187-231, 062008.

WADE, R. Governing the market: Economic Theory and the Role of Government in East Asian Industrialization. [S.1.]: Princeton University Press, 1990.

WILLIAMSON, J. A short history of the washignton consensus. In: The Washington Consensus Reconsidered. Oxford: Oxford University Press, 2008. p. 14-30. 